Historic, archived document

Do not assume content reflects current scientific knowledge, policies, or practices. 



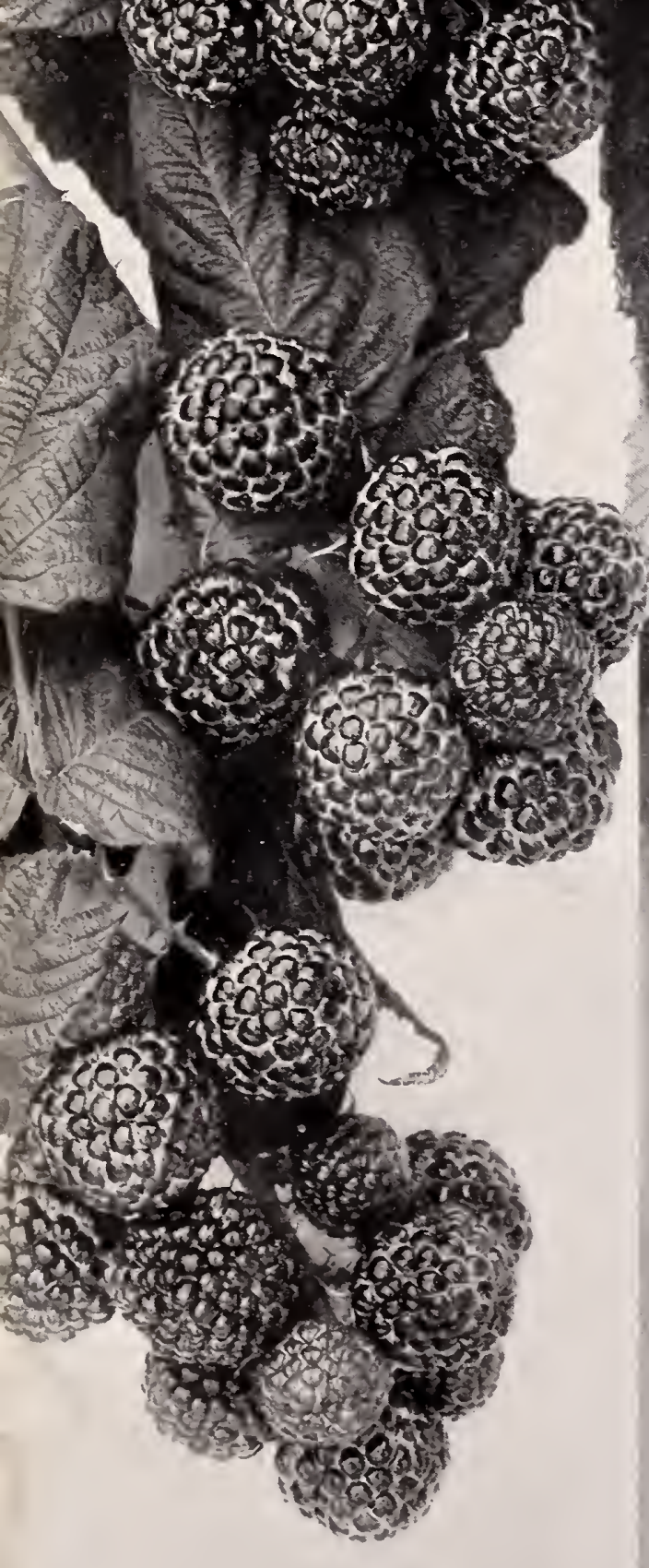

$6 \cos ^{2}, \mathrm{cos}$

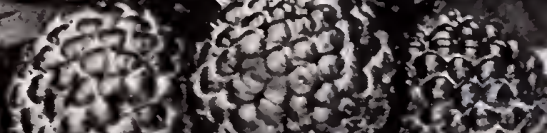

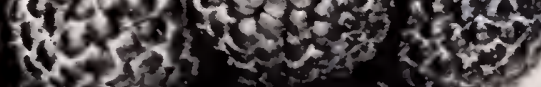
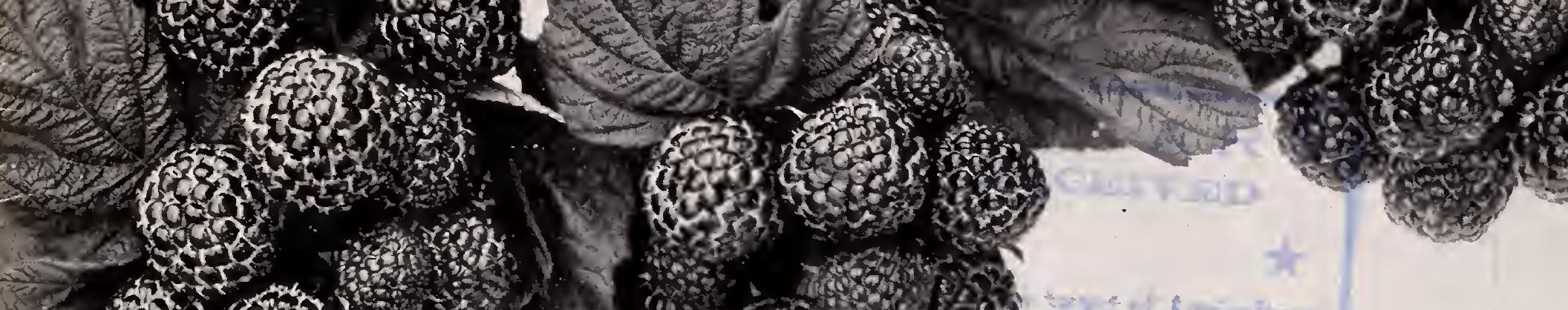

3ate 20

(W. $=-200$ (2)
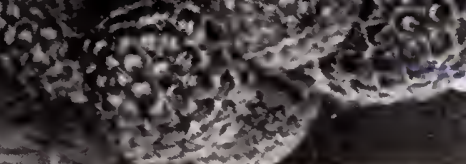

\section{FRUIT AND \\ ORNAMENTAL TREE BOOK}

PLUM FARMER

BLACK RASPBERRY

1915

\section{LANDSCAPE AND NURSERY} DEPARTMENT OF JAMES VICKS SONS. ROCHESTER, N.Y. 


\section{JAMES VICK'S SONS-SEEDS, BULBS, PLANTS, TREES}

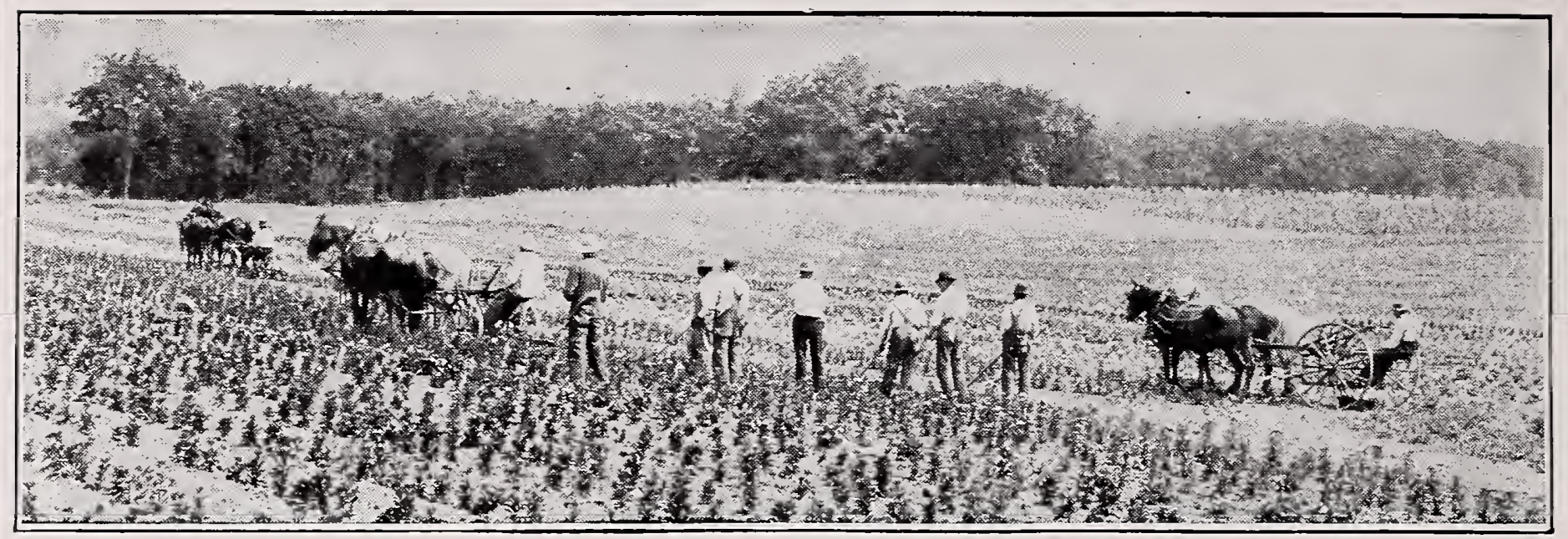

THOROUGH CULTIVATION MEANS-GOOD ROOTS-CLEAN LIMBS-HEALTHY TREES

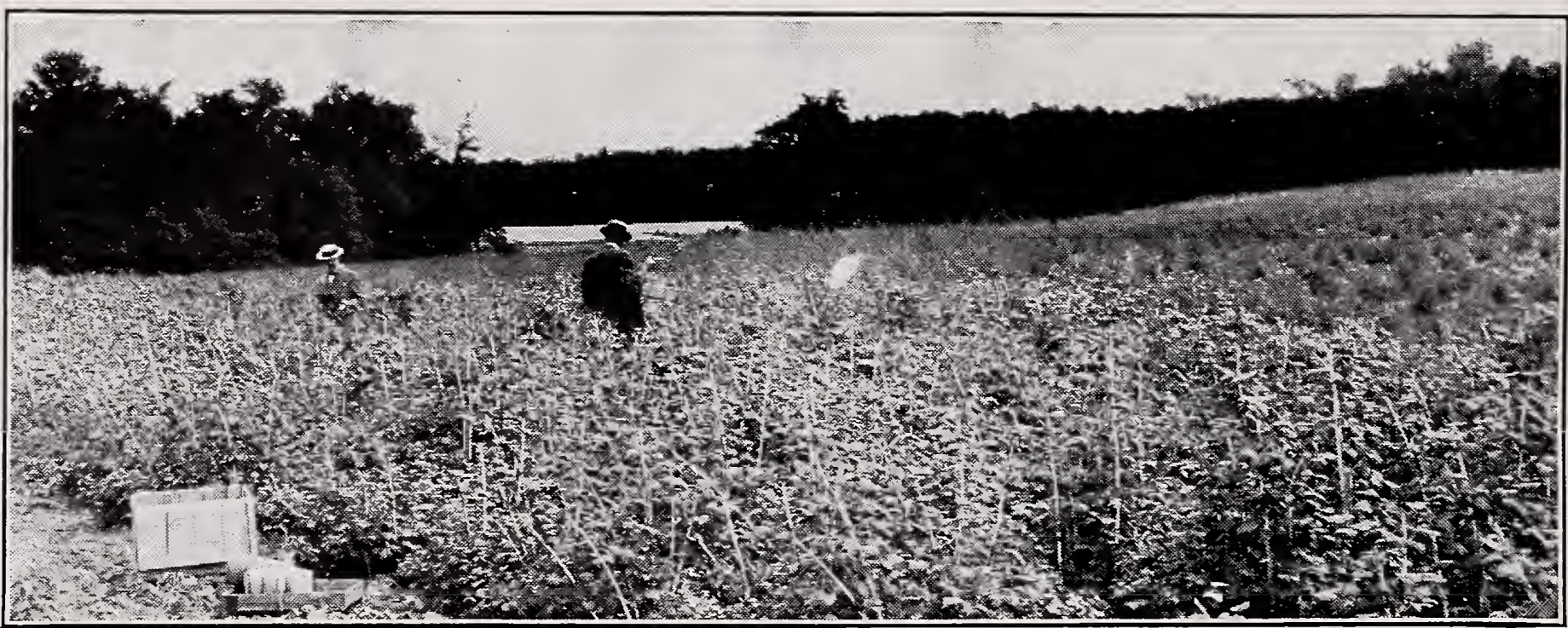

PLUM FARMER BLACK RASPBERRY FIELD ON OUR FARM AT BARNARDS, N. Y

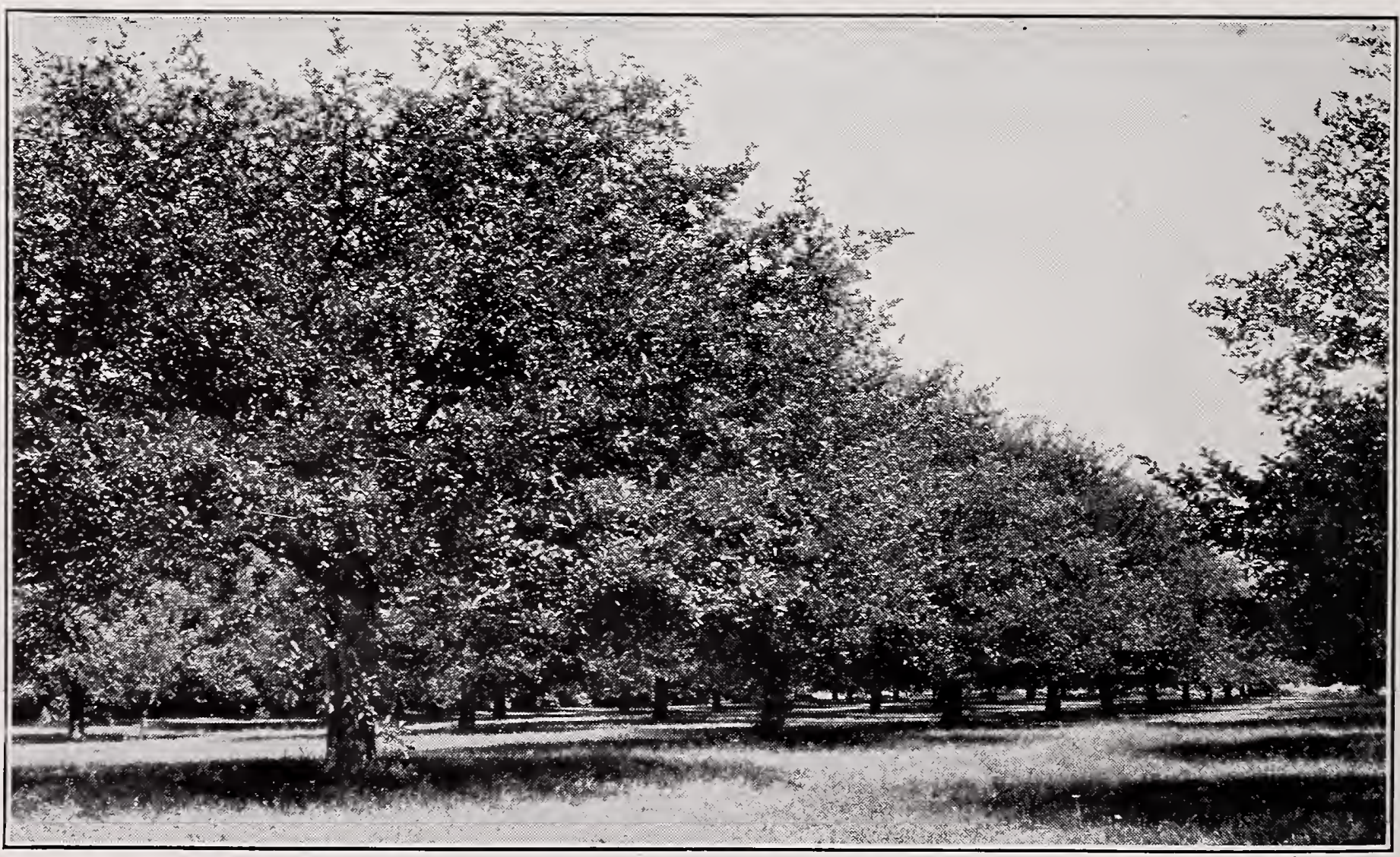




\section{By Special Arrangement}

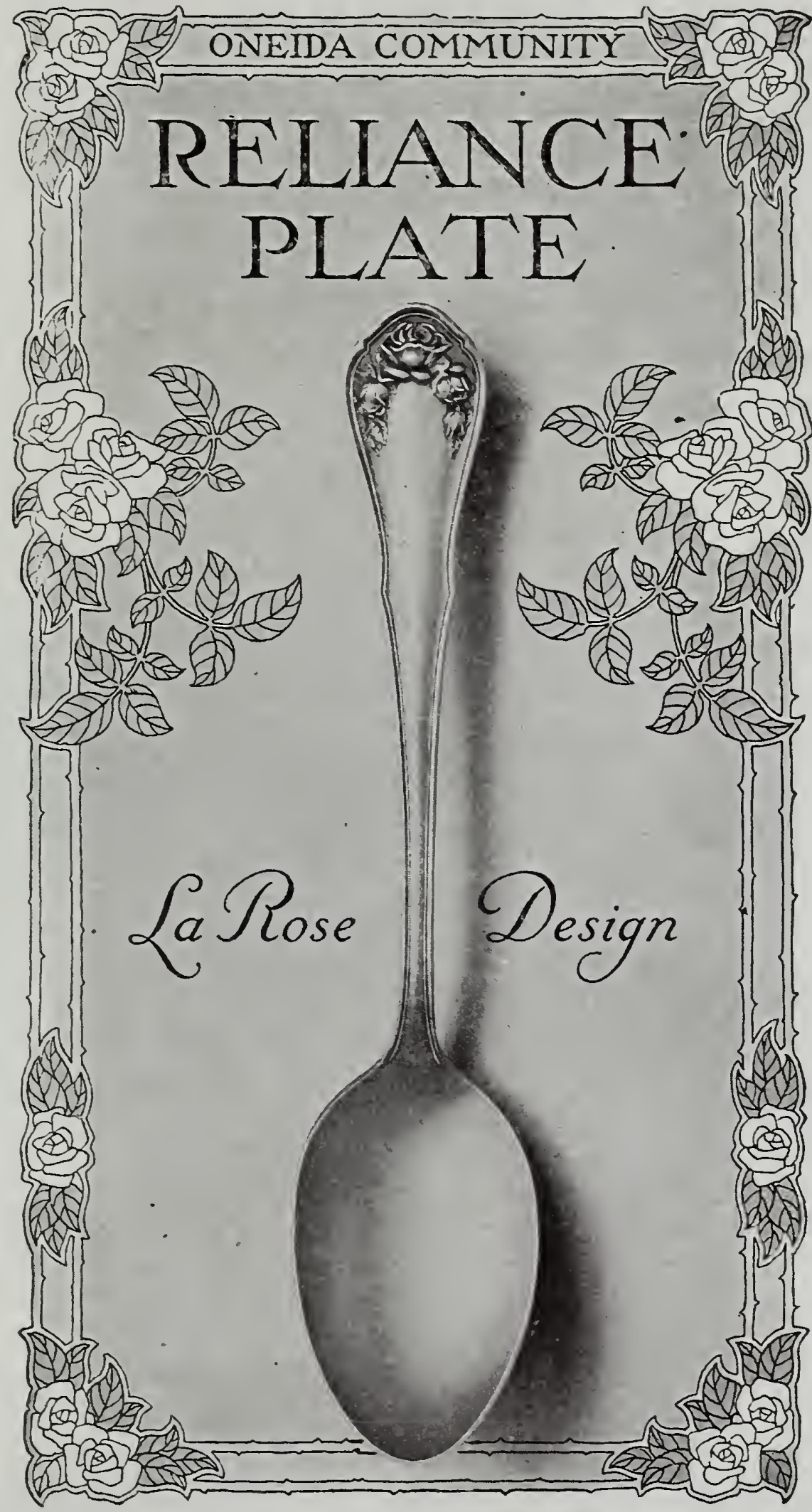

with the Oneida Community, Ltd., makers of high grade silverware, we have secured the exclusive privilege among seedsmen of their beautiful La Rose design Reliance Plate Silverware, either for sale or for premium offers. This design is among those you see advertised extensively by the Oneida Community, Ltd., in high grade magazines.

Reliance Plate is sold by thousands of the best jewelry dealers all over the United States and in Canada, but in not one of these stores do we believe you will find Community Reliance Silverware in a "cut rate" sale or on a "marked down" counter.

\section{Description and Guaran- tee of La Rose Design Silverware}

This silverware is the La Rose design in Reliance Plate made by the famous Oneida Community, makers of the finest silver plated ware in the world.

The base metal of Oneida Community Reliance Plate is the best nickel silver. The silver plate is applied by a special process. The goods are first heavily plated all over with pure silver, $25 \%$ more than standard Al plate. The pieces are then overlaid with a thick disk of pure silver on the portion most exposed to wear, making this part practically wear-proof. The wearing quality of Reliance Plate is so great that the Oneida Community guarantees it for 25 years' service in ordinary family use, a guarantee slip to this effect accompanying each piece.

Reliance Plate is manufactured throughout in accordance with the very best and latest ideas in spoon manufacture. The finish and workmanship have attained a uniform excellence made possible only by years of practical experience in spoon-making. The Oneida Community always interprets their guarantee very liberally and they can be absolutely relied upon. They are a very large concern, having a capital of $\$ 2,000,000$. They have been in business since 1848 and have been actively engaged in manufacturing spoons for over thirty years. Any statement they make can be absolutely relied upon, for they have a reputation for excellence and integrity in manufacture second to none in the country. 


\section{A PREMIUM OFFER that has never been equaled}

Oneida Community Reliance Silver Plate Given Away to Celebrate the Opening of Our Nursery Department

Conditions under which we make this offer to you-read carefully

Silverware will be sent for the amount of the order for Ornamental and Fruit Trees, Berry Bushes, etc., listed in our Fruit and Ornamental Book only

Orders must be sent to us before March 15th

State plainly which premium you want otherwise none will be sent Orders of different sizes entitle you to different premiums

With an Order for $\$ 1.50$ or Over.....1 Community Reliance Tea Spoon

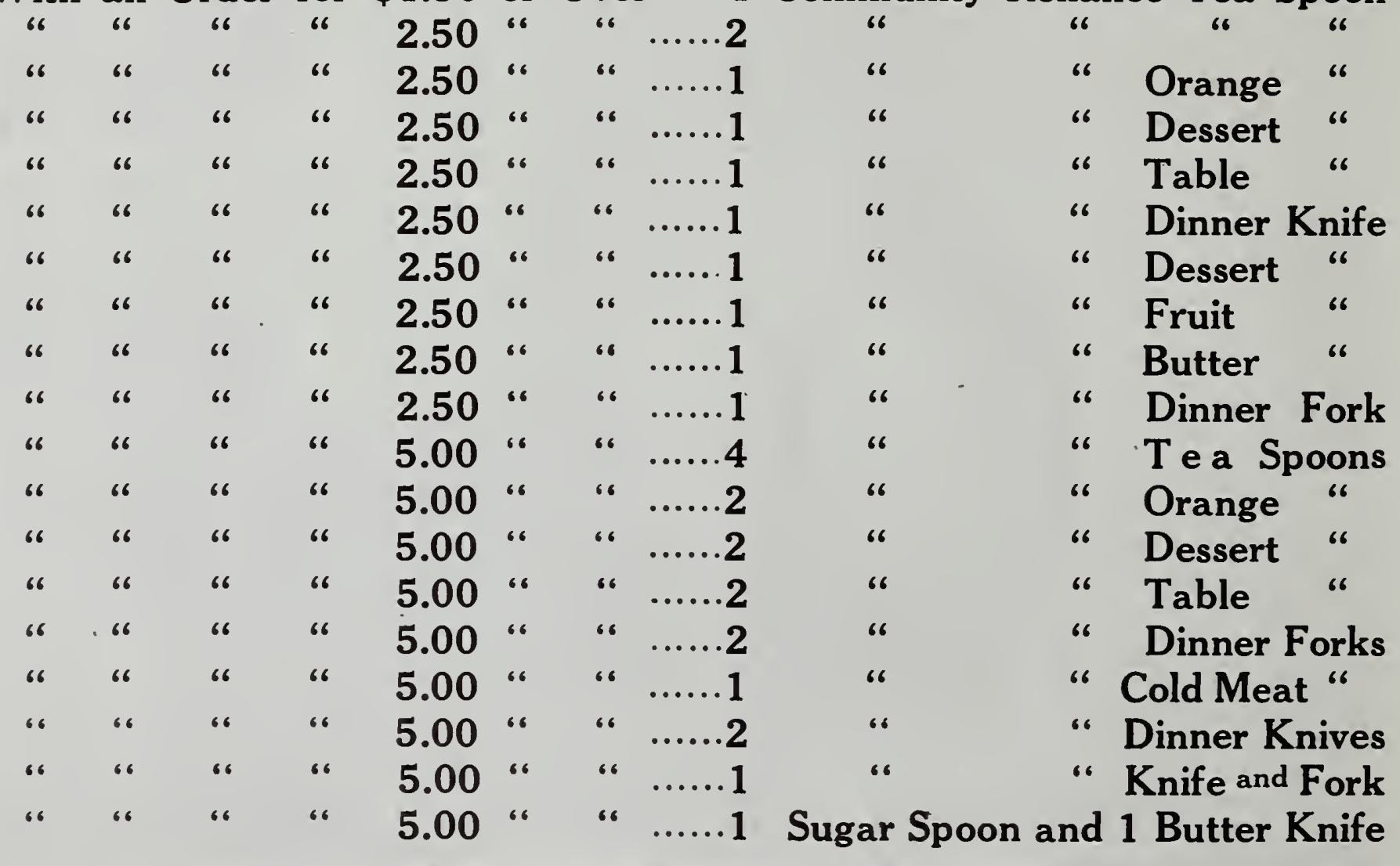

These offers apply only to orders taken from our Fruit and Ornamental Tree Book. They are not given with stock ordered from our Garden and Floral Guide. 


\section{James Vick's Sons - Trees a $x^{2}$ Plants

\section{Our New Department}

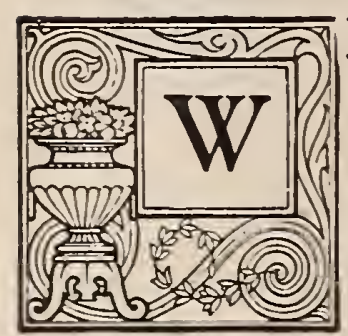

HILE primarily this house has been chiefly engaged in selling seeds, plants and bulbs, it has always had a large trade in small fruits and nursery stock. Each year the demand for these goods has increased. Sometimes we have been flooded with more orders than we expected. We remember more than one occasion when the quantity of our nursery orders has embarrassed our other departments in their efforts to handle seed and bulb orders immediately on their arrival at our office.

Inasmuch as we have never tried to push this department it has often occurred to us that probably the reason we receive so many orders is because this house has been so long and favorably known. At any rate the steadily increasing demand has obliged us to

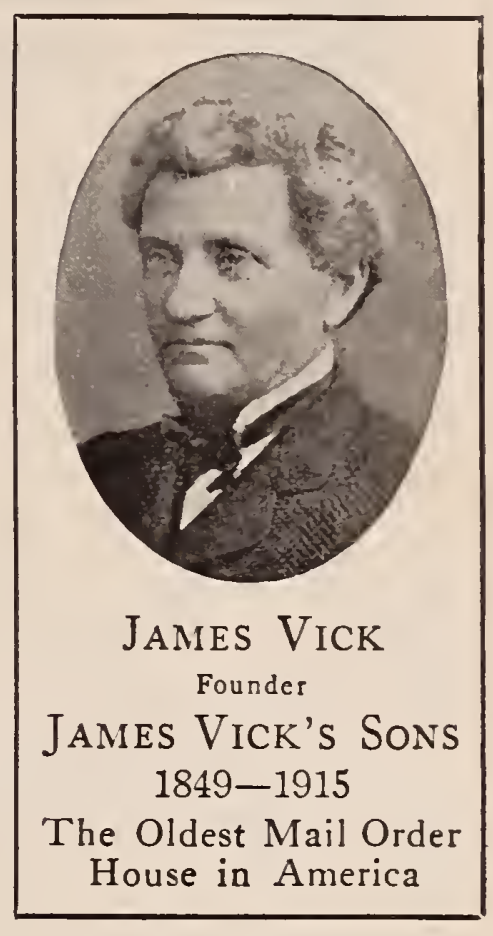
face the situation in this fashion: We must either make a special department for this work and give it special care and attention or else we must stop it altogether. In a certain sense our reputation is at stake. We cannot afford to do things half way. We have, therefore, decided to develop this branch of our business to keep step with other departments.

We consider ourselves extremely fortunate just at this point, in having at our command the services of a man who is a thorough nurseryman, who knows how to grow trees. He knows a good tree when he sees it. He has handled men in the packing yards. He knows how to answer questions and give sound advice. He has had a lot of experience in laying out private and public grounds. We have arranged this new department and given its superintendent instructions to make this one thing his business: To be sure that our customers get the best kinds of trees and bushes, and in every way see that our reputation for Vick Quality is maintained in this growing department as successfully as it is in other branches.

Finally we congratulate our customers, as well as ourselves, in the good fortune which makes it possible for us to open this new department and undertake this work under such a favorable combination of circumstances.

We shall try to make this Tree Book not only a catalog of the stock we have to sell, but a guide to help you in selecting the varieties of trees and bushes, and the proper way they should be planted to bring you the best results.

The varieties which we are listing have been very carefully selected. We shall offer none but those of known quality which have been thoroughly tested and tried out in different sections of the country. Our trees are the best that can be grown in a section famous throughout the country for the quality, size and hardiness of the stcck it produces.

By shipping direct from our farm to you we are able not only to make you very reasonable prices on high quality stock, but to give your orders personal care and attention. 


\section{Be Sure and Read This}

\section{JAMES VICKS SONS ESTABLISHED 1849 66 Years Selling by Mail}

ORDER NOW.-Do not wait until you are ready to plant. The earlier orders are placed the better it is for both you and ourselves. If it is necessary that your order be shipped on a certain date, state so plainly on the order sheet. We try to ship our orders in rotation-order early and you will get your stock early.

HOW TO ORDER.-Make out your order on our regular order sheet. State plainly how many and of what variety of trees and plants you want. Write your name and address and shipping directions carefully.

It will be a great convenience if all orders for the nursery department are kept separate from seed and plant orders, for fruit and ornamental trees simply cannot be packed with other goods, as it would upset shipping arrangements and delay expeditious handling of our goods. Even if you find it more convenient to send one remittance to cover both your seed, plant and bulb order and your nursery order, be sure that the nursery orders are sent on a separate sheet from orders for other goods.

SEND PAYMENT WITH YOUR ORDER.--Get a money order at your express or post office, or a draft at the nearest bank. If you send cash be sure and register your letter. Do not put silver loose in an envelope. You will lose it. MAKE MONEY ORDERS PAYABLE TO JAMES VICK'S SONS, ROCHESTER, N. Y.

RATES. -7 to 4 trees are sold at each rate. 5 to 49 are sold at 10 rate. 50 to 299 at 100 rate. 300 or more at 1,000 rate.

DO NOT CONFUSE OUR PRICES WITH THOSE ON CHEAP STOCK. WE SELL GOOD TREES AT REASONABLE PRICES. BUY FROM AN OLD RELIABLE HOUSE-“VICK QUALITY" KNOWN FOR SIXTY-SIX YEARS.

SPECIAL PRICES ON LARGE ORDERS.--Send us in a list of the number and variety of trees you want. We will give you special quotations on large orders.

OUR TERMS ARE CASH WITH ORDER.-Large shipments will be sent C. O. D. if one-fourth cash is sent along with the order.

NO PACKING CHARGES.-We do not charge for packing, boxing or delivering to freight or express companies at Rochester. Our prices are Free on Board cars at our nurseries. If you have no agent at your station and shipment has to be prepaid, notify us and we will prepay and bill charges to you after shipment.

OUR GUARANTEE.-We exercise care to have our sto'ck genuine and reliable, and hereby guarantee that if all, substantially all, or any. part of stock delivered, does not prove true to name as ordered, we will replace it free of charge; or refund the money paid for it, that being the measure of damages for a breach of the contract.

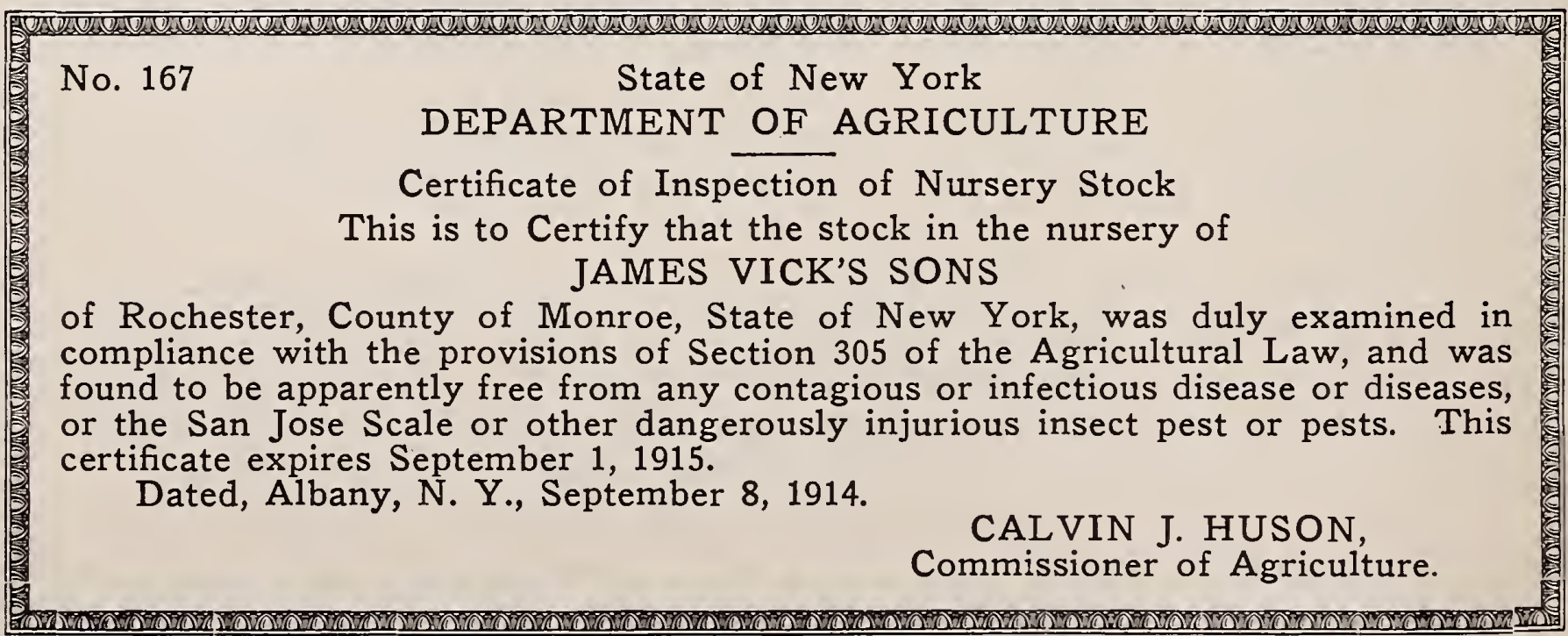




\section{To Make Your Plantings Successful}

Most of the failures experienced in the planting of Trees, Shrubs, etc., result from a want of knowledge of conditions necessary to success, or from a careless disregard of them. Many Nurserymen are blamed for what might easily have been avoided had the planter consulted the plain wants and requirements of the stock and given it at least a fair chance to grow and do well. We are interested in the success of every article we send out; we take the greatest pains to place every item in the hands of our customers in the best possible condition, and in order to furnish some precautions which our experience suggests, and urge to a more cautious and considerate culture, we give a few hints on such points as are most essential.

\section{How to Take Care of Trees on Arrival}

If not ready to plant on arrival, unpack the trees, but do not leave the roots exposed to freezing temperature. Dig a trench in some high and dry ground and heel in, covering the roots with earth and follow directly with plenty of water around the tree. You can leave them in the trenches until you are ready to set out. If frozen on arrival, leave in the boxes and place in cellar or in a cool, dark room that is free from frost, and let them remain until the frost has disappeared. If no cellar, cover with sawdust or bury in sandy soil until frost has gone. Do not expose frozen trees to heat, light or air. Trees frozen solid will not be injured if handled in this way. If too dry from exposure or transit, bury in earth or place in water from 10 to 20 hours.

The Preparation of the Soil.-For fruit trees the soil should be dry, either natural or made so by thorough drainage, as they will not live or thrive on a soil constantly saturated with stagnant moisture. It should also be well prepared by twice plowing, at least, beforehand, using the subsoil plow after the common one at the second plowing. On new, fresh lands, manuring will be unnecessary; but on lands exhausted by cropping, fertilizers must be applied, either by turning in heavy crops of clover, or well decomposed manure or compost. To ensure good growth of fruit trees, land should be in as good condition as for a crop of wheat, corn or potatoes.

Planting.-Make the holes large enough to admit the roots without any cramping or bending, and deep enough to bring the tree to its natural depth. The fine surface soil should be used in covering the roots, and this should be carefully worked among them. If the ground is dry it is well to pour in some water when the hole is partially filled. See that the ground is firmly and solidly packed over all parts of the roots by exerting the full weight of the planter upon it, so that there will be no opportunity for dry air or frost to enter and destroy roots deprived of the full benefit of their natural protection. Omission to pack the earth solidly is a most frequent cause of failure in planting nursery stock. Fill the holes even enough to be even with the surrounding surface after the fresh earth settles. Always remove the label when planting. If this is left until the tree is grown, the connecting wire often cuts into and destroys the trees and branch to which it may be attached. Never use wire in contact with roots. When planting dwarf trees set them low enough to cover the stock upon which they are budded, but not lower. Large standard trees should be staked and tied so that the wind will not loosen the roots. This should be so done that the bands will not chafe the trees. It is a very good way to drive two stakes and confine the trees between straw or hay bands stretched from stake to stake. Do not put manure in contact with the roots for it burns them.

Mulching.-This is properly done by placing a layer of coarse manure or litter, from three to six inches deep, about the tree, extending one or two feet further in each direction than the roots. This keeps the ground moist and of an even temperature; renders watering unnecessary, and is in all respects preferable. Trees properly mulched are more certain to live and also make better growth than those not so.

After-Culture.-Grass should not be allowed to grow about your trees or plants. The ground should be cultivated for a space of at least a foot outside the roots. If the ground is poor it should be enriched with surface applications of manure. Pruning should be varied according to the condition of the tree and the purpose of the planter. It should be done regularly each spring before the buds swell any. In this way the removal of large branches will be avoided.

Grape Vines.-Require a dry, mellow, well-drained soil, deeply worked and well enriched, with a warm, sunny exposure. In planting give the roots plenty of room and settle the soil firmly about them. A strong vine may be allowed to grow the first season without pruning; in November or December following, the growth should be cut 


\section{James Vicks Sons - Trees, , Dlants $^{2}$

back to three or four buds; the next season allow but two buds to grow, which should make canes seven to ten feet long and be cut back to four or five feet, ready for fastening to the trellis. Finer grapes and larger crops will be secured where there is not an excess of vine. For the subsequent pruning of vines, as well as trees, planters would do well to consult some practical works on the subject.

Berries.-Should have strong soil and be kept under constant cultivation. Mulching is of special value. Raspberries and Blackberries should have the old canes cut out each year, and new canes pinched off when three feet high. If the position is at all exposed, it is well to raise a mound between the hills late in the fall, bend the canes over this mound and peg them down during the winter. Strawberries should be mulched late in the fall; uncover the crowns early in the spring, remove the mulch after fruiting and spade in light dressing of manure. If set for fruit, keep the runners cut off.

Currants and Gooseberries should be mulched every spring and well pruned, so that new wood may have a chance to grow. The ground about them should be kept in good condition by manure and cultivation. The worms may be destroyed with certainty by applying White Hellebore powder shaken from a coarse bag as soon as they appear, and repeating the operation once or twice.

\section{Distance for Planting}

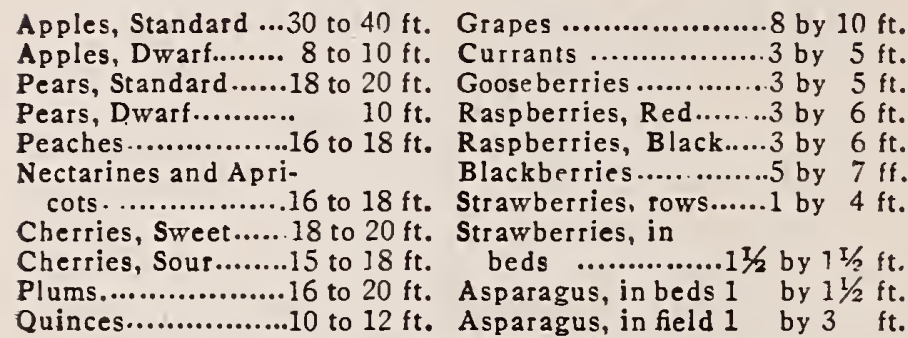

\section{Trees and Plants to the Acre}

2 feet each way.........10.890 3 feet each way......... 4,840

4 feet each way........ 2, 2,23

5 feet each way......... 1.742

6 feet each way......... 1,210

8 feet each way........ 681

10 feet each way........ 430

12 feet each way........ 302

15 feet each way........... 194 18 feet each way............ 135 20 feet each way............ 110 25 feet each way........... 70 30 feet each way........... 48 33 feet each way........ 40 40 feet each way........... 28

To estimate the number of plants required for an acre, at any given distance, multiply the distance between the rows by the distance between the plants, which will give the number of square feet allotted to each plant, and divide the number of square feet in an acre $(43,560)$ by this number, the quotient will be the number of plants required. THE BLACK RASPBERRIES

\section{Trimming}

It is surprising how many orchards you see planted out with the young trees left with the full amount of limbs on, just as they came from the nursery. By the accompanying drawing we endeavor to show how a young tree should be trimmed and planted:-One of the most necessary of all

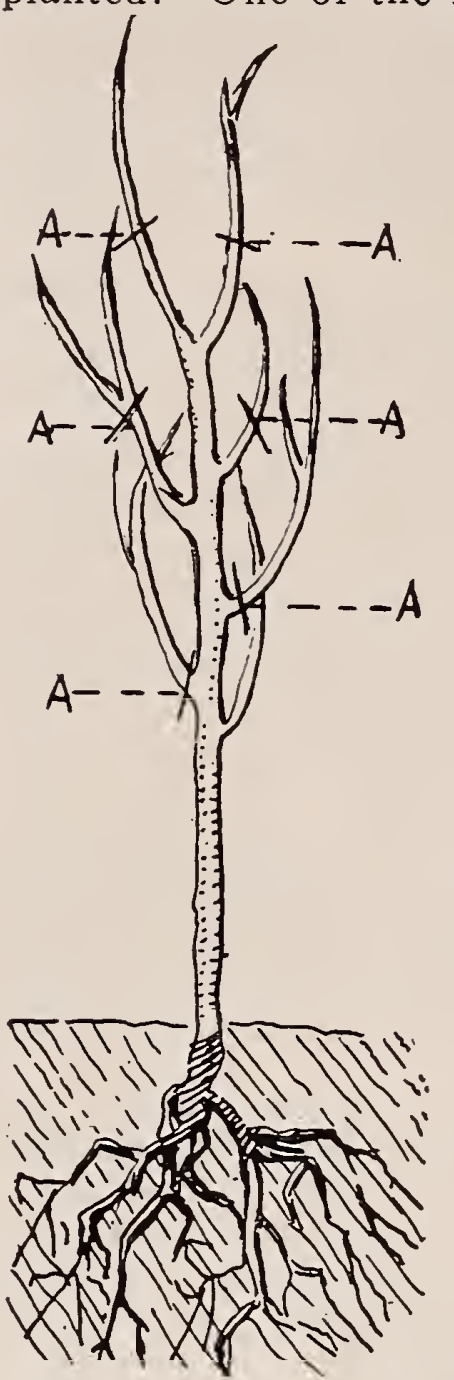

things is to make the hole $1 \mathrm{arge}$ enough to hold the entire root $\mathrm{s}$ y s t e m w e 11 spread out. Never crowd the roots. Plant the tree in the ground an inch deeper than it was in the nursery row. You can easily see the $\mathrm{mark}$ on $\mathrm{th} \mathrm{e}$ trunk.

Next is to trim the young tree the way you want it to grow. If a low headed tree is preferred, cut back the top leaving such limbs as you may want. In the drawing we have shown the most popular way of trimming young trees. This generally gives a m e d i u m height tree very w e 11 formed. The cross lines marked "A" show where the cut should be made. The two lower limbs are too low to be left on and should be cut off close to the trunk as marked by the lines "A."

If more pains were taken in setting out your stock, there would be less loss of trees to the planter.

\section{Age at Which Different Trees Fruit}

Standard Apples average 4 to 5 years.

Dwarf Apples,

St. Pears, 3 to 4 years

3 to 4 "

Gooseberries, 3 to 4 "

Grapes,

Quinces,

Blackberries,

Crab Apples,

Dwarf Pears,

Plums,

Currants,

Raspberries,

Roses generally bloom the season of planting. 


\section{Age that Apple Trees begin to Fruit}

Our fruit trees when shipped from the nursery are 2 years old. Peach trees are always 1 year old. The following list is not complete but it gives an idea to planters what varieties to select that will come into bearing quickly.

Three Years.-Bismark, Duchess of Oldenburg, Rome Beauty, Grimes Golden, Keswick, Primate, Pewaukee, Williams Favorite.

Four Years.-Arkansas Black, Ben Davis, Black Twig, Caroline Red June, Gano, Longfield, Mann, Maiden's Blush, Peerless, Tetofsky; Wagener, Wealthy, Yellow Transparent.

Five Years.-Cooper's Market, Early Harvest, Fallawater, Fameuse, King, McIntosh Red, Newtown Pippin, N. W. Greening, Pewaukee, Red Astrachan, Rawle's Janet, R. I. Greening, Sops of Wine, Stark, Twenty Ounce, Walter Pease, Wolf River, Winesap, York Imperial.

Seven to Nine Years.-Baldwin, Belleflower, Early Beauty, Spitzenburg, Fall Pippin, Golden Russett, Gravenstein, Hubbardson Nonesuch, Mann, Mother, Northern Spy, Pumpkin Siveet, Russett, Rambo, Red Betigheimer, Stump, Sutton Beauty, Sweet Bough, Talman Sweet, Seek-no-Further.

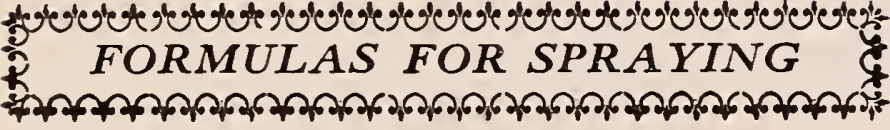

\section{Arsenite of Lead}

Arsenite of Lead, 4 to 6 lbs. Water, 100 gallons.

\section{Amoniacal Copper Carbonate}

Copper Carbonate, 5 ounces. Ammonia, 2 pts. Water, 50 gallons.

The copper carbonate is best dissolved in large bottles, where it will keep indefinitely, as it should be diluted with water as required. For the same purpose as Bordeaux.

\section{Copper Sulphate Solution}

Copper Sulphate, 1 pound. Water, 25. gallons.

This should be used only before the foliage appears. It is easily applied, and acts as a general germicide and disinfectant. In simple solution copper sulphate is very injurious to foliage. When lime is added, as in making Bordeaux Mixture, its corrosive action is neutranzed and injury to the foliage prevented. In this way a larger quantity of bluestone may be used, and it adheres to the foliage better by the agency of lime.

\section{Bordeaux Mixture}

Copper Sulphate .......4 4 pounds

Quicklime ..........4 4 pounds

Water ............50 gallons

To destroy leaf-eating insects, add four ounces of Paris Green. For Peach, use three pounds each of copper sulphate and lime, and three ounces of Paris Green, on account of the tenderness of the foliage.

Ferrocyanide Test.-Dissolve one ounce of yellow prussiate of potash in a pint of water and label "POISON." Drop it into the mixture and if it turns brown more milk of lime should be added. Add milk of lime until the solution will not turn browi.

\section{Hellebore}

Fresh White Hellebore, 1 oz. Water, 3 gallons.

\section{Kerosene Emulsion}

Hard Soap ......... $1 / 2$ pound Boiling Water ........... I galion

Kerosene ............ 2 gallons

Dissolve the soap in hot water and while hot add the oil. Pump the liquid back into itself 5 or 10 minutes until it becomes a creamy mass.

For a 10 per cent emulsion add 17 gallons of water to 3 gallons of the above emulsion.

For a 15 per cent emulsion add $10 \mathrm{I} / 2$ gallons of water to 3 gallons of the above emulsion.

\section{Lime Sulphur Salt Solution}

Stone Lime ...........15 pounds

Flower of Sulphur......15 pounds

Common Salt .........15 pounds

Put lime in kettle, add three or four buckets hot water. While lime is boiling, add sulphur and stir briskly. If contents of kettle is likely to boil over, add another bucket of hot water. When the lime and sulphur have boiled for a few minutes, add the salt, and cook until the solution becomes dark amber in color. Usually an hour is sufficiently long to cook the mixture, but if it is not of the right color at this time, the cooking should be continued. When the mixture has been properly cooked, there ought not to be more than a pint or so of residue left in the kettle. At the beginning of the cooking, stir continually, but after a few minutes, occasional stirrings will suffice. When the cooking is completed, the solution should be straincd through a fine sieve, made for the purpose, or through a gunny sack into the pumping barrel or tank and made up to 50 gallons of hot water. The mixture should be applied while hot and preferably as soon after making as possible, always bearing in mind to keep it well agitated while the pump is in operation. Pumps and accessories used should be well washed and cleaned after each lime of using.

\section{Tobacco}

Boil tobacco stems, and use at the rate of two gallons to each pound of stems, for sucking insects. 


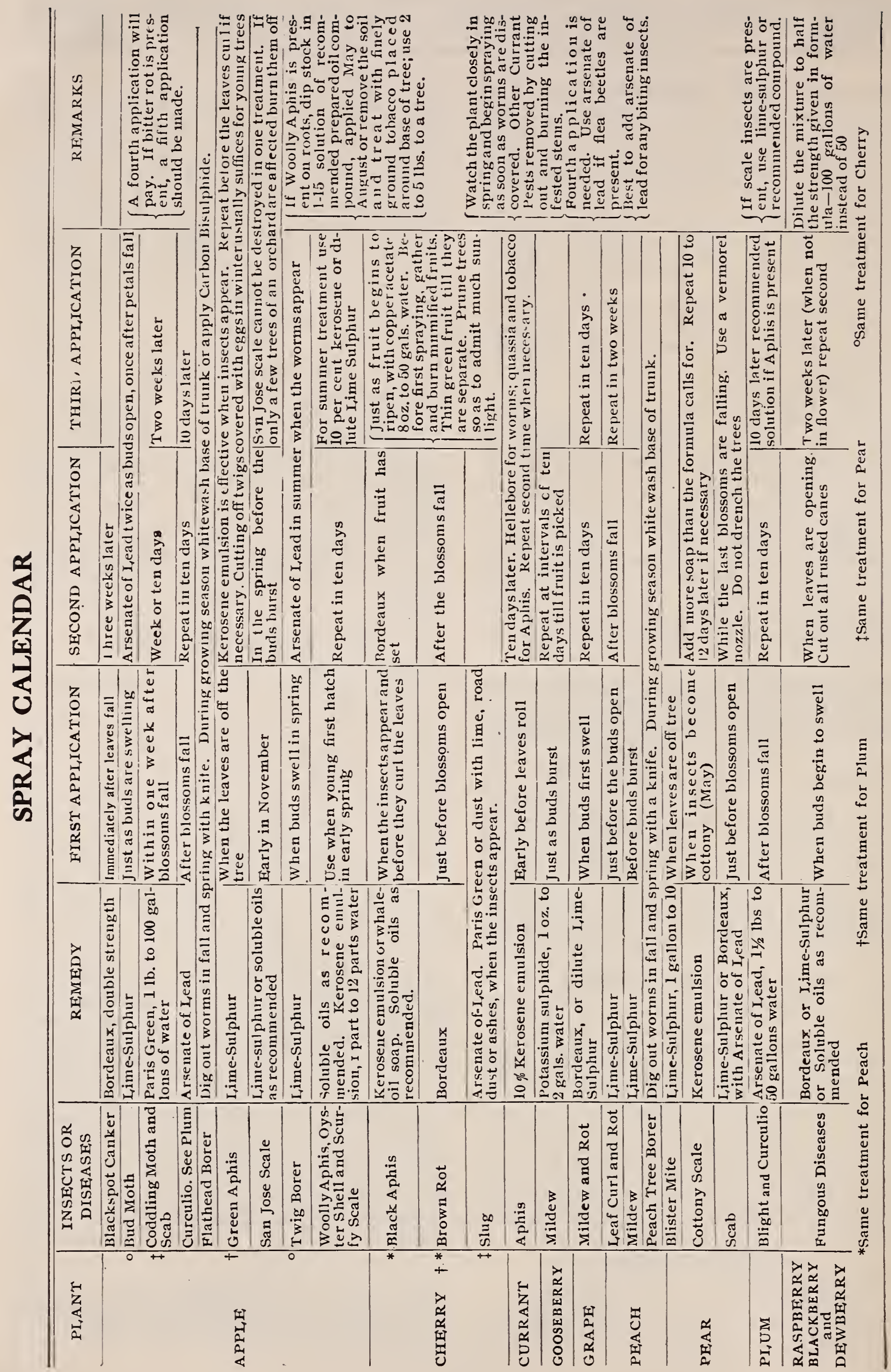




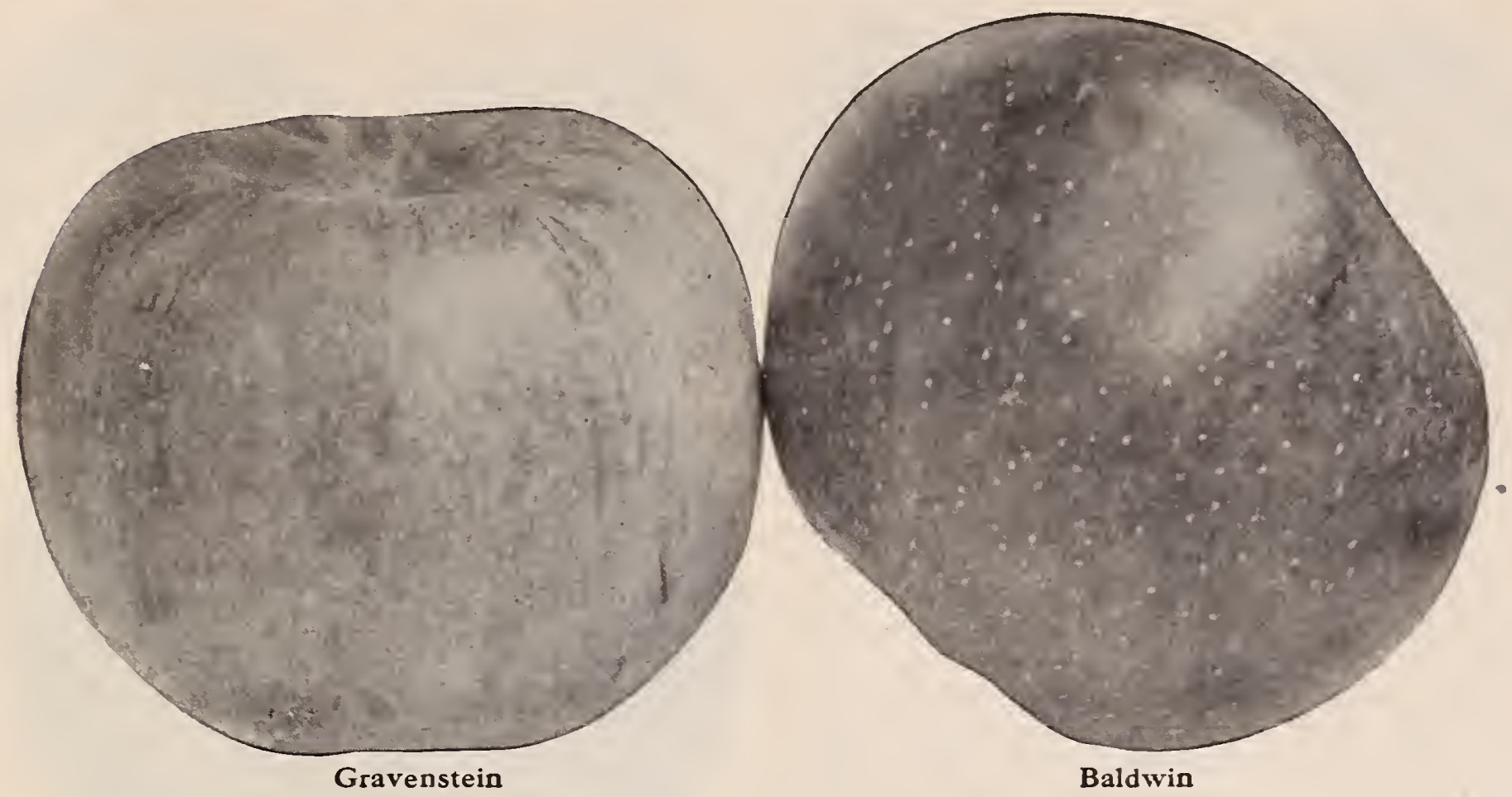

\section{Apples}

Heading all other fruits is the apple. It is the most widely known, best liked and most useful of all. A careful selection of varieties will give you ripe fruit from early August until the following May. In this book we list and describe the best of the Summer, Autumn and Winter kinds. The trees we offer you are of standard "Vick Quality," hardy, clean and well rooted; with straight trunks and well branched heads.

\section{PRICES OF APPLE TREES}

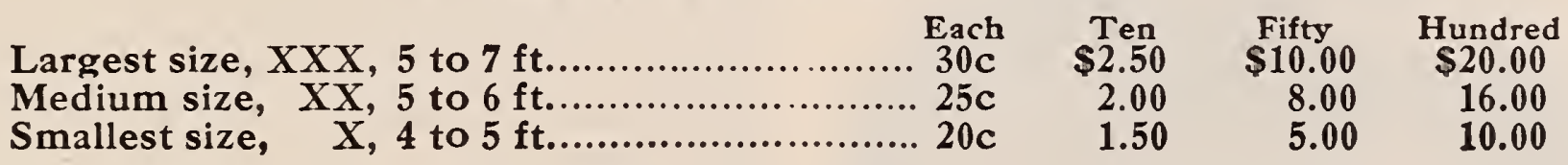

Baldwin (Winter).-Without question, the leading commercial variety in New England, New York, Ontario, Ohio, Michigan and in many sections from Colorado to Washington. You are taking absolutely no chances when investing your money in this variety. Absolutely dependable. Fruit large, firm, moderately coarse, crisp, rather tender, very juicy, agreeably subacid. Skin yellow or greenish, blushed, mottled and striped with bright red and deep carmine. Prevailing effect is bright red. Tree large, very vigorous, strong and hardy. Ripens in November, lasts until May.

Ben Davis (Winter). - Finest keeper known; fine-looking; large, round; yellow, with red stripes; flesh white, juicy, subacid, coarse. Tree rapid in growth, healthy and vigorous, bears early, annually and abundantly. Good filler.

Carolina Red June (Summer).-An attractive little apple, deep red over yellow, tender, brisk, subacid. Late July to early winter.

Duchess of Oldenburg (Summer).-Medium size; red striped; flesh white, juicy and excellent flavored. Trees are natural dwarf growers and make fine fillers; require small root and branch space. Crops nearly a1ways large. Thrives and yields well of high-grade fruit at all elevations in Pennsylvania, New York, Ohio and other northcrn states. Tree among the hardiest and one of the few that will stand the climate of Iowa, Minnesota, Montana, and other cold locations. You can depend on Duchess to yield apples you can sell for good prices.

Delicious (Vinter).-Of peculiar and distinctive shape; brilliant dark red, shading off to golden yellow at the blossom end; flesh fine-grained, juicy, crisp and melting; flavor sweet, with a slight acid taste. This apple is gaining in favor each year as one of the profitable commercial varieties. Tree vigorous, thrifty and a good, dependable cropper.

Early Harvest (Summer). - An early summer apple of medium size, pale yellow, tender, juicy and of fine flavor. A great cooking and desert apple and very popular for the home orchard. Tree bears large crops regularly.

Fall Pippin (Fall).-Large, yellow, tender, juicy and rich. A favorite cooking and eating apple. 


\section{James Vicks Sons - Trees

Fameuse or "Snow Apple" (Fall).-A handsome red striped apple. Flesh snowy white, juicy and of fine flavor. Very popular eating apple.

Golden Russett (Winter).-Clear golden russett color. Good in cold sections. Brings good prices. Keeps until May in cold cellar.

Gano.-Originated in Missouri: Fruit good size and smooth; deep red, shaded on sunny side to mahogany; very attractive. Flesh pale yellow, fine grain; tender, pleasant, mild, sub-acid. Excellent shipper and keeper. Tree healthy, vigorous and hardy; annual and productive bearer. Jan. to May.

Gravenstein (Fall).-Orange yellow with stripes of light and dark red; tender, juicy, aromatic, subacid. Good size and attractive appearance. Ripens late in September, lasts to early November.

Greening (Rhode Island Greening).-An old standby in all apple sections, more widely planted than any other kind, except the Baldwin. Its color is against it for export. One of the best cooking apples and good for table use. Fruit large, green, sometimes with red cheek. Tree is very vigorous and a big producer, though it does not bear very young. Season October to February. Origin Rhode Island.

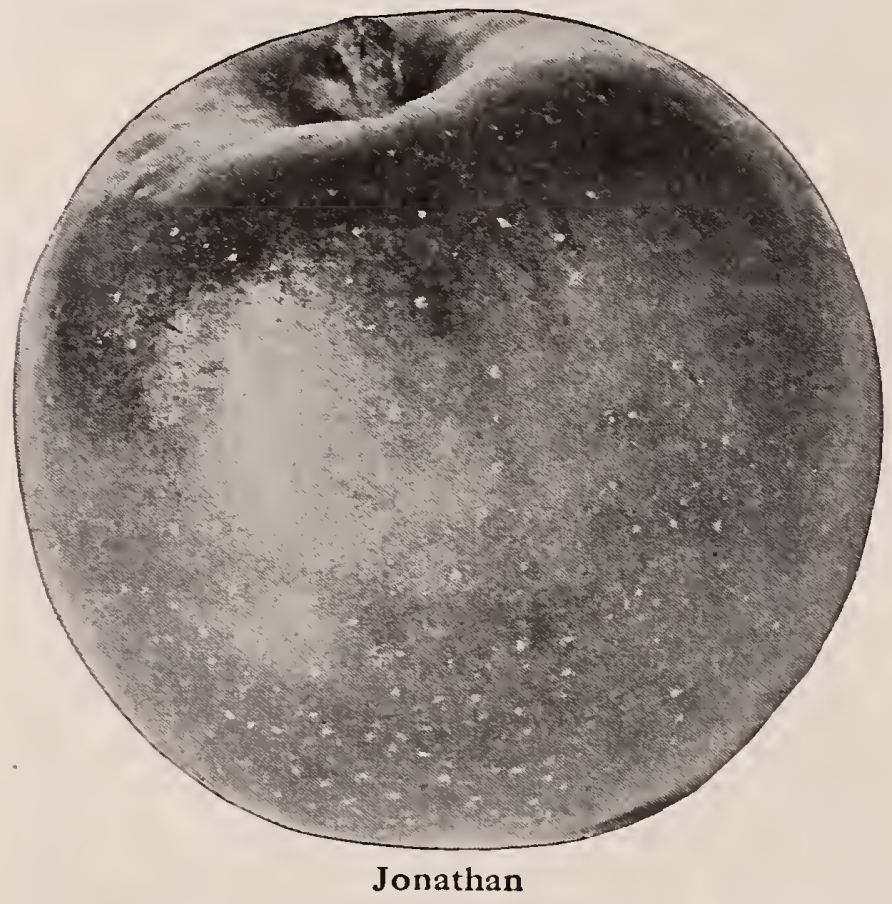

Jonathan (Winter).-Very late keeper. Medium to large; brilliant red; very highly flavored, juicy, fine-grained, tender, mild, subacid. Quality is fine for home use and for marketing in large or small quantities. Will keep well without special care, and also stand much handling. Tree long-lived, but comes into bearing very young and produces big crops every year. Pennsylvania, Maryland, and all states to the west produce fine Jonathans. Farther north it ripens a little small, but everywhere is of best quality. Always bring highest prices.
Grimes Golden (Winter).-Attractive in form and excellent either for dessert or culinary use. Fruit large, firm, tender, crisp, juicy, rich, aromatic, subacid. Skin clear deep yellow with scattering pale yellow or russet dots. Tree vigorous. Ripens in November, lasts to February.

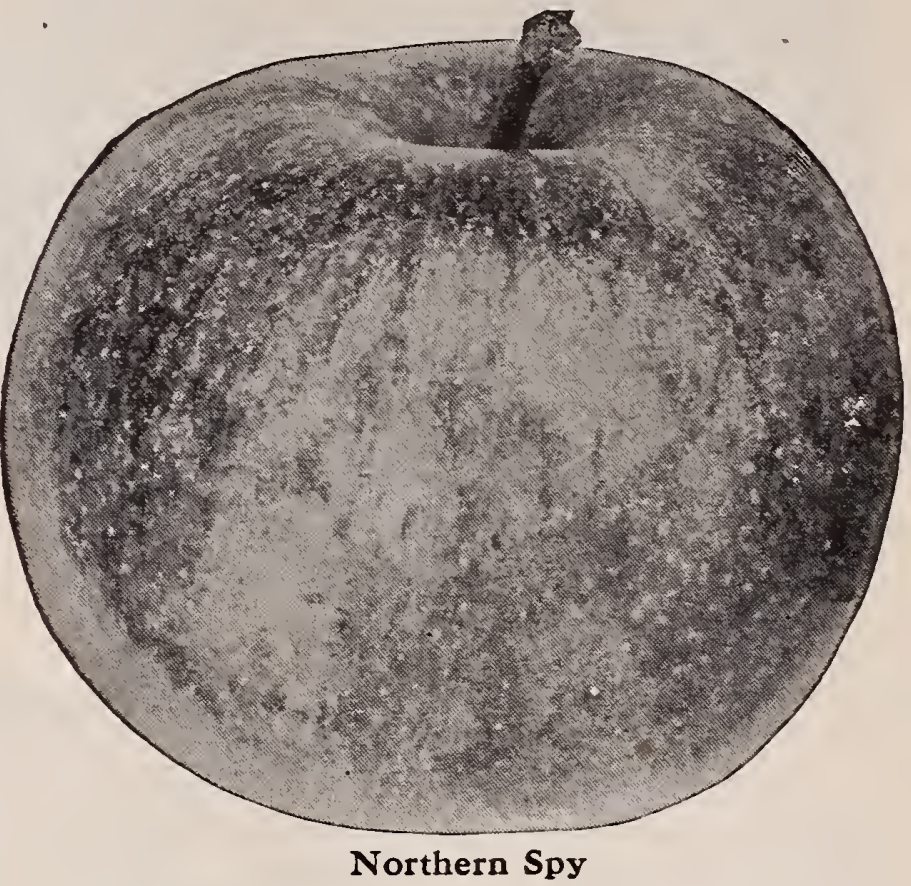

Northern Spy.-This variety stands third in commercial importance in the Eastern fruit sections. Fruit large, fine color, bright red unless shaded too much, with a delicate bloom. Flesh is juicy, crisp and tender. Many persons prefer it to any other for table use or cooking. Always brings highest market prices. Ready to eat in November and will keep in storage until June.

Greening (Northwestern).-A greenish yellow apple sometimes faintly marked with red. One of the best winter apples for sections that are too cold for the R. I. Greening. Tree thrifty and very hardy. Fruit large and of good flaver.

Maiden Blush (Fall).-One of the most beautiful; pale lemon with crimson cheek; flesh white, tender and crisp. An old-time favorite which is still one of the most popular apples. Tree vigorous and good bearer.

McIntosh Red (Fall). - A Canadian apple; keeps long, but is mellow and good to use almost from the time it is picked till the next crop comes. Requires no special storage to be kept like fresh. Fruit tender, juicy, subacid. Quick and spreading grower; long-lived; bears big crops. McIntosh Red is the apple now making Montana's Bitter Root Valley famous. There, as well as in New England, New York and Michigan, its high quality and attractive appearance put it in the lead. It is extra good for all the higher and colder sections. Trees bear in three and four years, and make fine fillers. See picture on Back Cover. 


\section{James Vickis Sons -Trees, ${ }^{\circ}$ Plants \\ ROCHESTER. N.Y. THE FLOWER CITY}

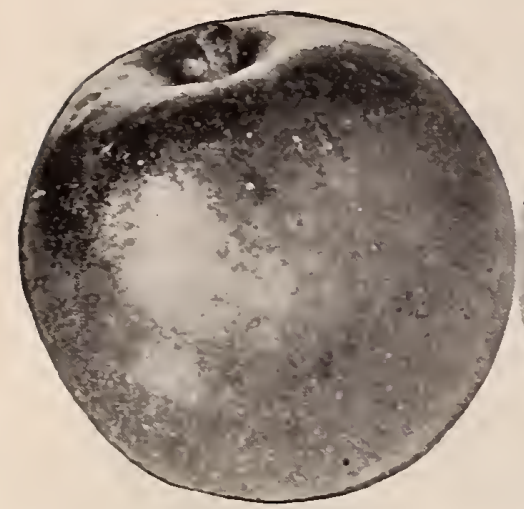

Sutton Beauty

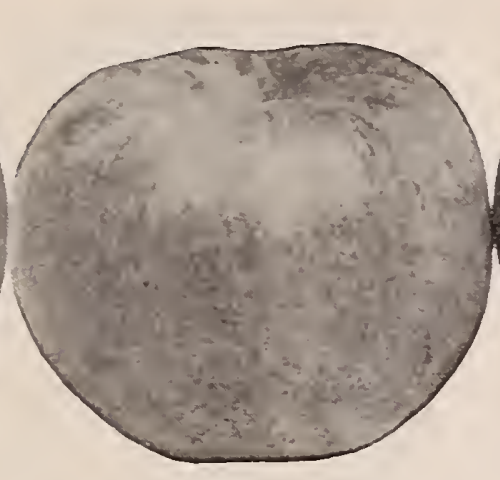

Banana

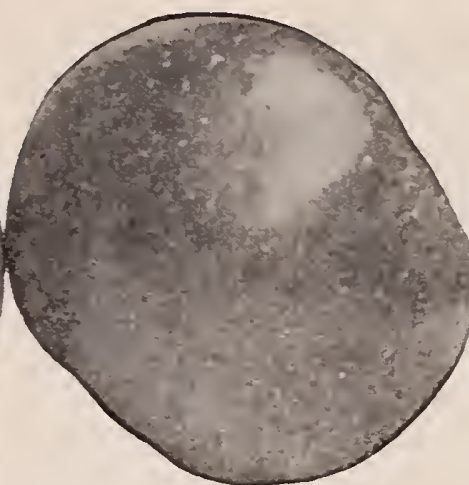

Stayman

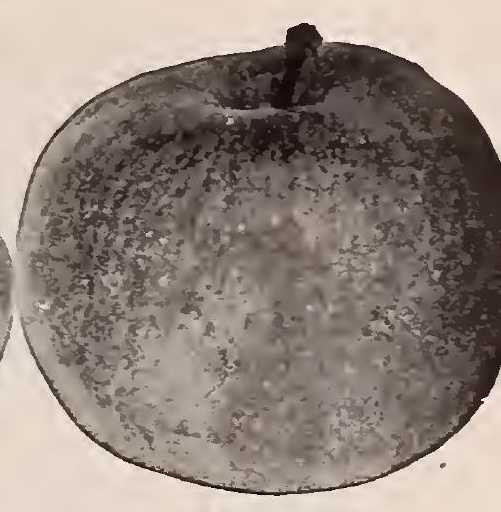

King

King of Tomkins County.-A superb red apple of extraordinary size and fair quality; the flesh is slightly coarse, but tender and vinous. An abundant annual bearer. November to March.

Red Astrachan (Summer).-A reliable cropper that comes into bearing young. Fruit medium size, crisp, tender, juicy, subacid. Skin pale yellow striped with deep crimson, covered with a distinct bluish bloom. Tree medium size, vigorous and hardy. Ripens in July, lasts until September.

Rome Beauty (Winter).-A very fine market varicty for the northern and westeinn states. Fruit very large, skin yellow, mottled with bright red; in highly colored specimens almost solid red on exposed cheek, striped with bright carmine. Flesh crisp, juicy, agreeable, mild, subacid. Ripens in November, lasts to April or May.

Roxbury Russet (Winter).-The most popular russet apple. Fruit large, firm, moderately tender, juicy, sprightly, subacid, good. Skin almost smooth but usually covered with greenish to yellowish brown russet. Highly colored specimens develop a bronze blush. Tree medium to large, vigorous and hardy. Season December to May.

Stayman (Stayman's Winesap) (Winter). - Very late keeper, but mellows for use in the fall. Medium to large, attractive; green and yellow, almost hidden by dark red stripes; flesh yellow; plenty of juice; quality the finest. Tree a quick and large grower, and seems to prefer dry soils and those not so rich and heavy. The apple to plant on dry hills where the soil is thin and water often decidedly lacking. Bears young, often producing a barrel to a tree when five years old. Bears every year, crops uniformly heavy. Stayman is now planted in nearly all new orchards in the East, to a large extent. You cannot find a better sort in the whole list, either for bearing habit, size of fruits, looks or quality.

Sutton Beauty.-A leading market apple in Massachusetts, where it originated, in western New York, and in some other sections. Medium to large, roundish, waxen yellow, with brilliant blush of red; tender,

juicy, subacid, of good flavor and good keeping quality. The tree grows and produces freely. November to April.

Spitzenburg.-Medium-sized apple completely corered with red. The flesh is of good quality, crisp, juicy, subacid. When well grown and packed in boxes the fruit brings a very handsome price. Its season is between R. I. Greening and Baldwin. In cold storage Spitzenburg may be held until June.

Stark (TVinter).-Long keeper and a reliable commercial sort. Fruit large, round, greenish yellow, with red stripes; flesh yellow, crisp, and mildly acid. Tree a regular bearer; reliable and satisfactory in an orchard. One of the strongest growers we have, even more so than Northern Spy. Desirable trees to top-rwork other sorts on.

Sweet Bough.-A large pale yellow apple, one of the really good summer varieties and best early sweet apple. Sweet Bough ripens through a long season, the tree is a very young and prolific bearer and long lived. This variety should be in erery orchard. Fruit begins ripening in August.

Talman Sweet.-Splendid sweet winter apple. Light yellow in color with a faint blush cheek. Tree is a good grower, long lived and very hardy. Comes in bearing at an early age and is a reliable cropper. Season November to April.

Twenty Ounce.-Very large, yellow and red, tender, juicy. crisp, subacid; productive. October to January.

Wagener.-This is one of the varieties that bear at an early age. The tree is a quick grower and very thrifty. Planted as a filler for orchards, bears an abundance of fruit when young; of dwarf habit. The fruit is medium to large, skin tough and bright light red color; flesh whitish, firm, crisp, tender, very juicy and subacid; of the very best quality. Season is from October to February or later.

Winter Banana (Winter).-A magnificent dessert apple, which on account of its attractive appearance and fine quality commands a readier sale and higher prices than most apples. Packed in boxes for the fancy 
trade it is in ready demand. The fruit is large and keeps all winter. Flesh whitish, tinged with pale yellow, firm, crisp, tender, subacid. Skin clear pale yellow with beautiful pinkish red blush. Tree vigorous and hardy. Ripens in December, lasts until April.

Wolf River.-Fruit very large; yellow, nearly overspread with red. Tree a stout grower, early bearer and exceedingly productive. While these large fruits are apt to drop more easily than those of medium size, yet the higher price offsets it. December to February.

Yellow Transparent (Early Summer).Medium to large; tender, juicy, of fine flavor, subacid, fragrant. Trees very young bearers and yield big crops every year. Hardy, dwarf growers; prefer thin soil, such as hillsides and upland. One of the few kinds that grow and bear as well North as South. Will stand Canadian winters, as well as Georgia summers. By many this is considered the best of all extra-early apples, and comes into market when the demand for summer apples is extra strong; consequently it always brings the best prices. It is "one of the most valuable apples in our list.

York Imperial (Johnson's Fine Winter) (Winter).-This is one of the leading commercial varieties of the Middle Atlantic States. Very valuable on account of its unusually attractive appearance and fine keeping qualities. Fruit large, firm, crisp, moderately juicy, mild subacid or nearly sweet. Skin green or yellow, covered with light red and striped with carmine. Tree vigorous and hardy. Ripens in January, lasts until April or May.

\section{Dwarf Apples}

Dwarf apples commence bearing fruit the second year after planting and are especially desirable for village or city gardens. The big advantage of these dwarf trees is that they do not attain a size any greater than peach, plum, etc. Heretofore city people have been obliged to buy all their apples, because the size of their garden plot would not enable them to plant standard trees on account of the amount of space these standard trees required. These dwarf trees bear when very young and bear very abundantly. There is no question as to the desirability of being able to go out into your own fruit garden and pick fruit from trees of your own growing and eat it when in the freshest condition. These dwarf trees open up a new avenue to the people who have gardens of a limited size.

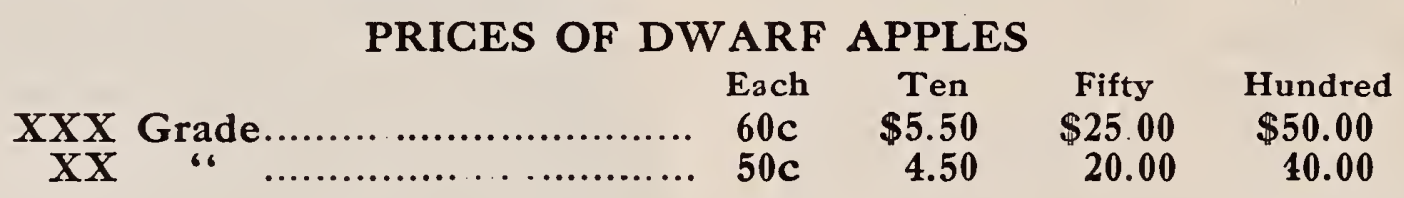

LIST OF DWARF APPLES WE SELL SHOWN IN PICTURE BELOW: Famuse R. I. Greening Baldwin Duchess Winter Banana Wealthy

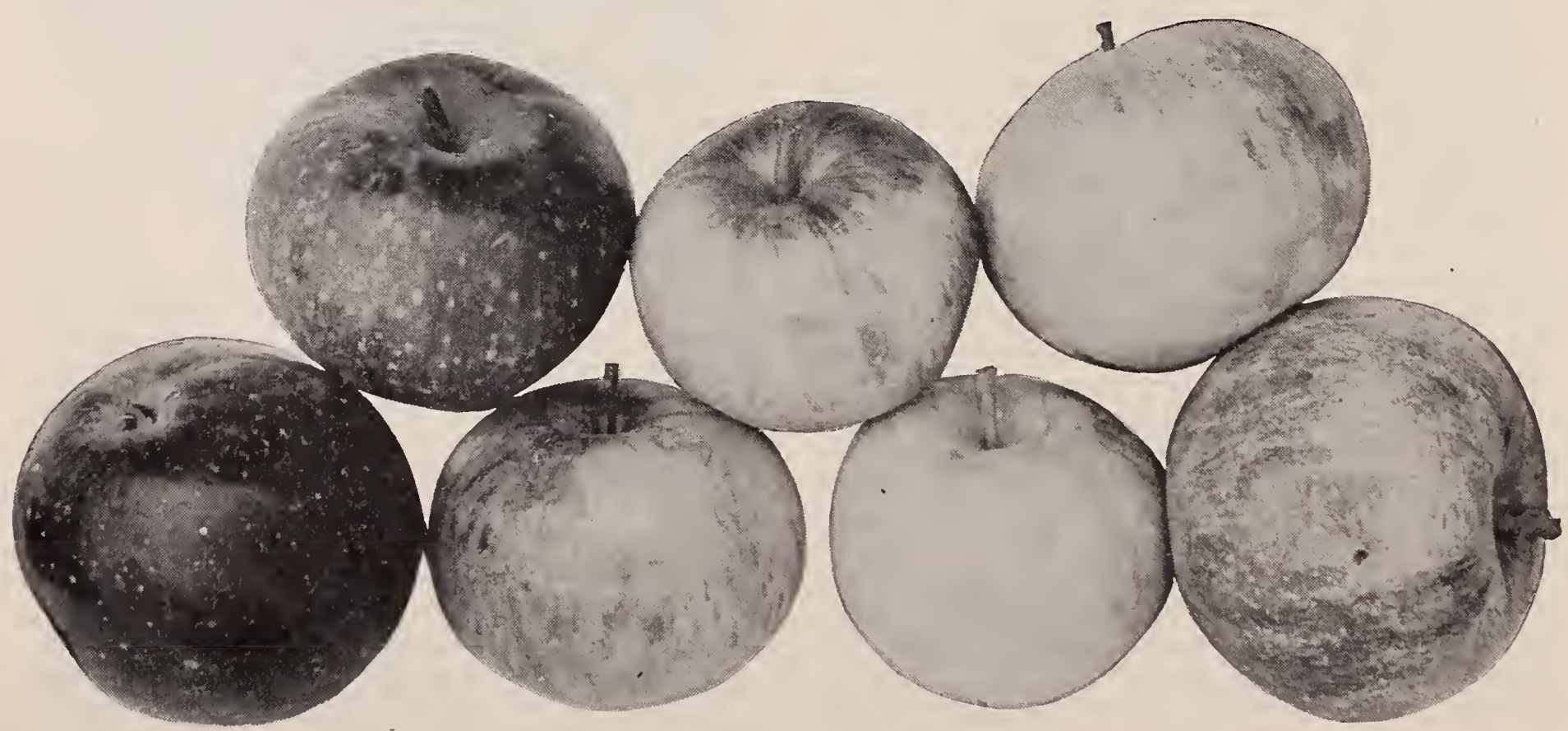




\section{James Vicks Sons - Trees, , Plants

\section{Crab Apples}

As an ornamental fruit, and for jellies, preserving, etc., the Crab Apple is unequalled. All are very hardy and prolific, come into bearing when very young, and command a ready and profitable market.

\section{PRICES ON 2-YEAR-OLD TREES}

$\begin{array}{ccc}\text { XXX Grade, largest size } & \text { Each } & 10 \\ \text { XX } & 35 \mathrm{c} & \$ 3.00 \\ \text { medium “" } & 30 \mathrm{c} & \mathbf{2 . 5 0}\end{array}$

Excelsior.-Fruit very large, being nearly as large as a medium sized apple. Color yellow splashed with red. Flesh white, firm, crisp and juicy, very good in quality. Season early Sept.

Hyslop.-Large, dark red, flesh yellow, subacid; productive, hardy and popular. October.

Transcendant.-Large, yellow with rich crimson cheek. An improved Siberian Crab. September.

Whitney.-A very hardy and prolific variety. Fruit is handsome and delicious. Excels for making fine jellies and preserves. Season late September and October.

\section{Hundreds of Barrels of Apples to} sell every Fall from our model orchard in charge of the New York State Experimental Station. Write for prices.

\section{Quinces}

Succeeding nearly everywhere as it does, the consumption of Quinces can easily be increased ten-fold. The demand exists-it needs only to be supplied. As a fruit for preserves, jellies and syrup, it takes a position of first rank-the good housewife is as car.eful to put up a supply of them as she is sure to lay by for the winter a stock of Montmorency Cherries.

\section{PRICES OF QUINCE TREES}

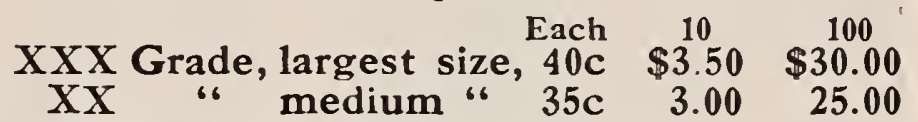

Bourgeat. - This tree produces large crops of exceedingly large and handsome fruit, of a rich golden color. It ripens soon after Orange, but will keep until mid-winter. It is very hardy and free from leaf blight.

Champion.-Will bear more quickly than any other variety. Trees in the nursery row often bear when two years old. The fruit is large and handsome. Flesh cooks as tender as an apple and without hard spots or cores. Very fine for preserves, jellies, marmalades, etc. The tree is vigorous, hardy and very productive. Champion is a fine all around quince. Ripens in November.

Orange.-More largely planted than any other variety. One of the old varieties that always bear and give good satisfaction wherever planted. Orange is large, bright golden yellow. Cooks very tender and has a great flavor. There is always a demand for this quince.

\section{Nut Trees}

The past few years have witnesscd a remarkable development in the planting of nut-bearing trees. Probably no branch of tree cultivation pays larger profits or is as well assured of a profitable market. The immense importations of foreign nuts erery year give some idea of the market to be supplied. Few farms but contain land, that, if planted to nut-bearing trees, would pay better than anything else to which it could be devoted; the nuts in many cases paying better than farm crops or fruits, while most kinds are making a growth of valuable timber, that will of itself pay a large per cent. on the investment.

Our native nut-bearing trees are admirably adapted for planting in streets, farm lanes, pastures, etc., for shade, ornament and profitable returns.

American Sweet Chestnut. - A well known forest and nut-bearing tree; of great value for ornamental purposes. 50 cts. each, $\$ 4.50$ for 10.

Black Walnut.-The well known native species; hardy, prolific and valuable; timber in point of durability is difficult to excel. 50 cts. each, $\$ 4.50$ for 10 .

Butternut.-A fine native tree producing a large longish nut which is prized for its sweet, oily, nutritious kernel. $50 \mathrm{cts}$. each, $\$ 4.50$ for 10.

English Walnut.-The fruit of this being so much larger and better flavored than our native species, gives it the preference for cultivation over the latter in localities where it will succeed. 50 cts. each, $\$ 4.50$ for 10.

Japan, Walnut.-The nuts are considerably larger than the common hickory nut, and borne in clusters of fifteen ta twenty. The shell is a little thicker than that of the English Walnut, which it resembles in a general way. The trees begin to bear when two or three years old. $50 \mathrm{cts}$. each, $\$ 4.50$ for 10 . 

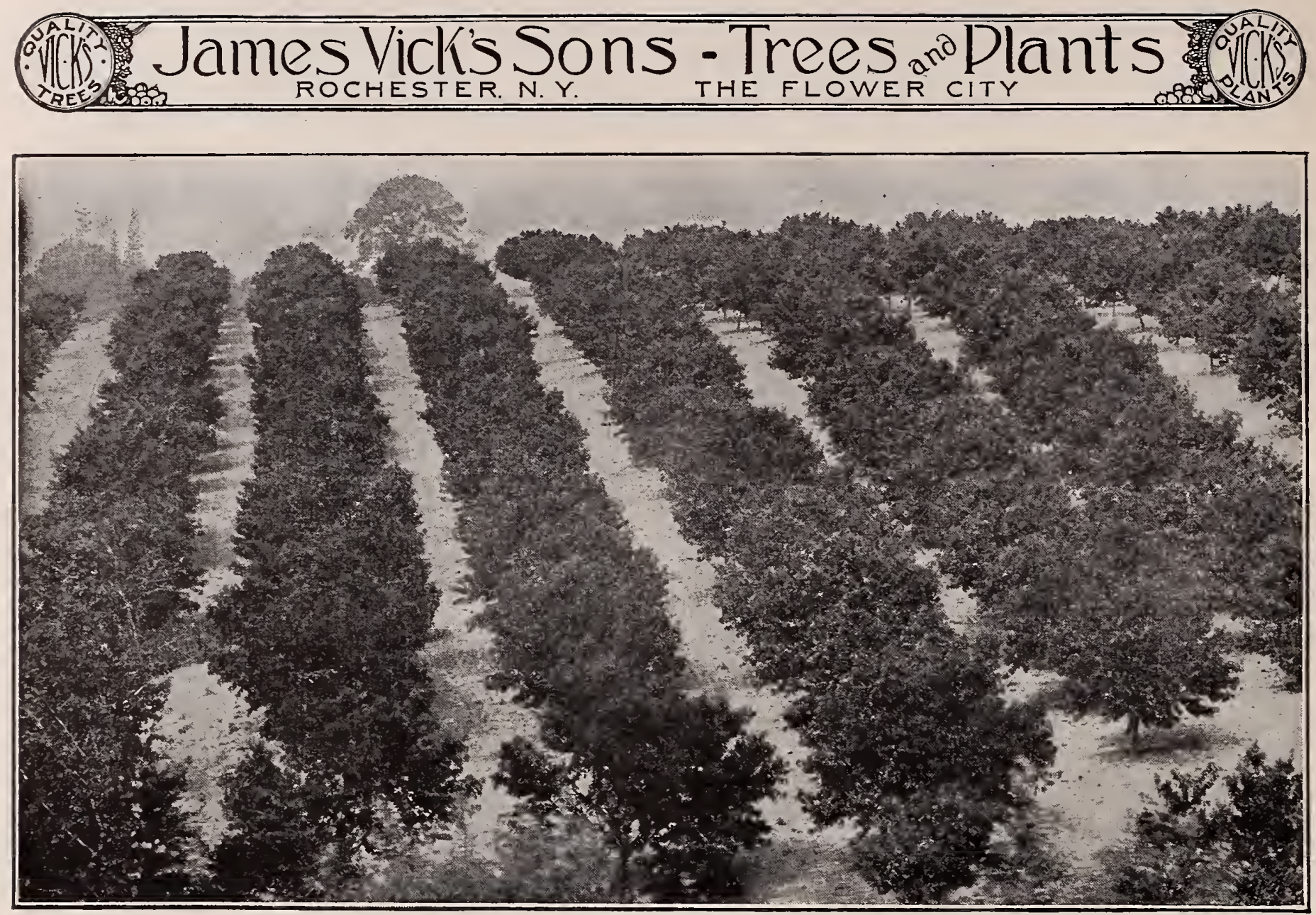

A Corner of an Elberta Orchard that Made Its Owner Rich

\section{Peaches}

The varieties we offer have been carefully selected. None but those whose worth has been proven are listed. The.variety to ripen earliest is listed first, the one following next, etc. These kinds cover a season of ripening from June to November.

\section{PRICES OF PEACH TREES}

\begin{tabular}{|c|c|c|c|c|c|}
\hline \multirow{2}{*}{\multicolumn{2}{|c|}{ XXX Grade, 4 to $6 \mathrm{ft} .$, Extra $\ldots \ldots \ldots \ldots \ldots \ldots \ldots \ldots$}} & \\
\hline & & Each & Ten & Fifty & Hundrec \\
\hline & 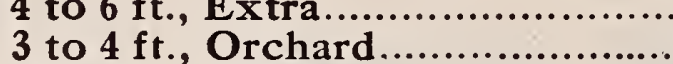 & $\begin{array}{l}20 \mathrm{c} \\
20 \mathrm{c}\end{array}$ & $\begin{array}{r}\$ 200 \\
1.50\end{array}$ & $\begin{array}{r}\$ 6.00 \\
4.50\end{array}$ & $\begin{array}{r}\$ 12.00 \\
900\end{array}$ \\
\hline$\overline{\mathbf{X}}$ & $3 \mathrm{ft} .$, Smaller... & $15 c$ & 1.00 & 3.00 & 6.00 \\
\hline
\end{tabular}

Greensboro.-A large, yellowish white peach with a crimson cheek. Very hardy and not subject to rot. Flesh is juicy and of fine quality. A good, early commercial variety. Freestone.

Triumph.-This is a very early variety; it is almost freestone. The flesh is yellow and of very good quality. The fruit is large, skin yellow with crimson cheek. Ripens around the first of August.

Carman.-A new, hardy, rot-proof peach ripening from the middle to end of July. Fruit is large, oval shaped, yellowish white. Flesh is creamy white, slightly tinted with red, juicy and fine. Carman is a fine shipper and is freestone.

Yellow St. John.-A beautiful yellow peach, medium to large in size. The skin is brilliantly flushed on the sunny side with bright deep crimson. The flesh is yellow, tender, juicy and altogether of extra-fine quality. Free. The tree is a strong grower and bears heavy crops every season. So early, this peach reaches the market at a time when the demand for early fruit is at its height.

Belle of Georgia.-Ripens first half of August. Fruit very large and most attractive in color and shape, with a light red cheek; flesh white, firm and delicious; in all ways the quality is fine. Trees grow quickly and shapely, are hardy and prolific. Free.

Crawford's Early (Freestone).-Last of August or beginning of September. A magnificent large yellow peach of excellent quality. In our estimation the best flavored and best variety for the home garden. Not as good a shipper as Elberta, but better flavored. Most people, when they buy peaches, ask for Crawford's as they know little about any other varieties. The trees are vigorous and productive.

Champion (Freestone). - Ripens about August 10th. An excellent, showy white peach. Fruit large, creamy-white with beautiful red cheek. Sweet, tender, juicy, of very high quality and a good shipper. Trees are hardy and productive. 


\section{James Vickis Sons - Trees $x^{*}$ Plants

Fitzgerald.-Origin Canada. Fully equal to Crawford Early in sizc, quality and color, with much smaller pit; a very early bearer, often when two years from bud; extra hardy, succeeding in Canada and in Michigan perfectly; fruit large, brilliant yellow with red cheek; highest quality; ripens after Crawford's Early. Freestonc.

Mountain Rose.-A favorite in New Jersey where it ripens early and grows to large size for so early a peach. A reliable cropper. Color white with carmine cheek, inside creamy white, abounding in rich, sweet juice. Considered first quality for dessert. Early August. Origin, Ncw Jersey.

Niagara.-Fruit a beautiful golden yellow blushed with brilliant red. Resembles the Elberta very much, but is larger in size. It has been thoroughly tested by extensive orchard planting near Rochester, N. Y., and found to be an unusually fine commercial variety. The quality and flavor of this peach is exceptional. It is free from yellows and leaf curl and is a good bearer.

Kalamazoo.-A large yellow peach of very good quality. Tree is hardy and very productive. Popular in Michigan, Ohio, Pennsylvania and New York. A good freestone commercial variety.

Elberta.-The best peach of its season for all markets as it has grand shipping qualities. Probably the grcatest commercial peach on the market today. The fruit is large, yellow with red cheek, juicy and highly flavored. Flesh is yellow and fine. Pit perfectly free. Tree is vigorous, hardy and a good uniform cropper. Ripens about ten days later than Early Crawford, late September.

\section{Chair's Choice.-} A very large deep yellow peach with red cheek. Has yellow flesh that is firm and of fine flaror. Pit is perfectly free. Tree is a strong grower and good bearer. Ripens just before Smock. October.

Crosby.-A beautiful yellow freestone peach with very small pit. Excellent flavor, 1 a rge size, color orange-yellow, with carmine on the sunny side. Very beautiful; tree of willowy growth, like Wager; rather dwarf; ripens between Early and Late Crawford.
Crawford Late.-Fruit large size; yellow with dull red check. Flesh yellow. T'ree vigorous and productive. Fine late September variety. Freestone.

Smock.-A large sized peach having a yellow color with a red check. The flesh is ycllow and juicy. One of the best varicties. Freestone.

Stump (or Stump the World).-Very large, roundish; skin is white with a bright red check; flesh is white, juicy and good. Tree is rigorous and productive. Ripens near the end of September and is freestone.

Wonderful.-A large peach very uniform in size and shape. Has a rich golden yellow color nearly corcred with bright crimson. Very handsome and attractive. The flesh is yellow, rich and highly flavored. It is delicious and very firm. This variety has a very small freestone pit and the flesh around it is red. Wonderful ripens near the middle of October. 

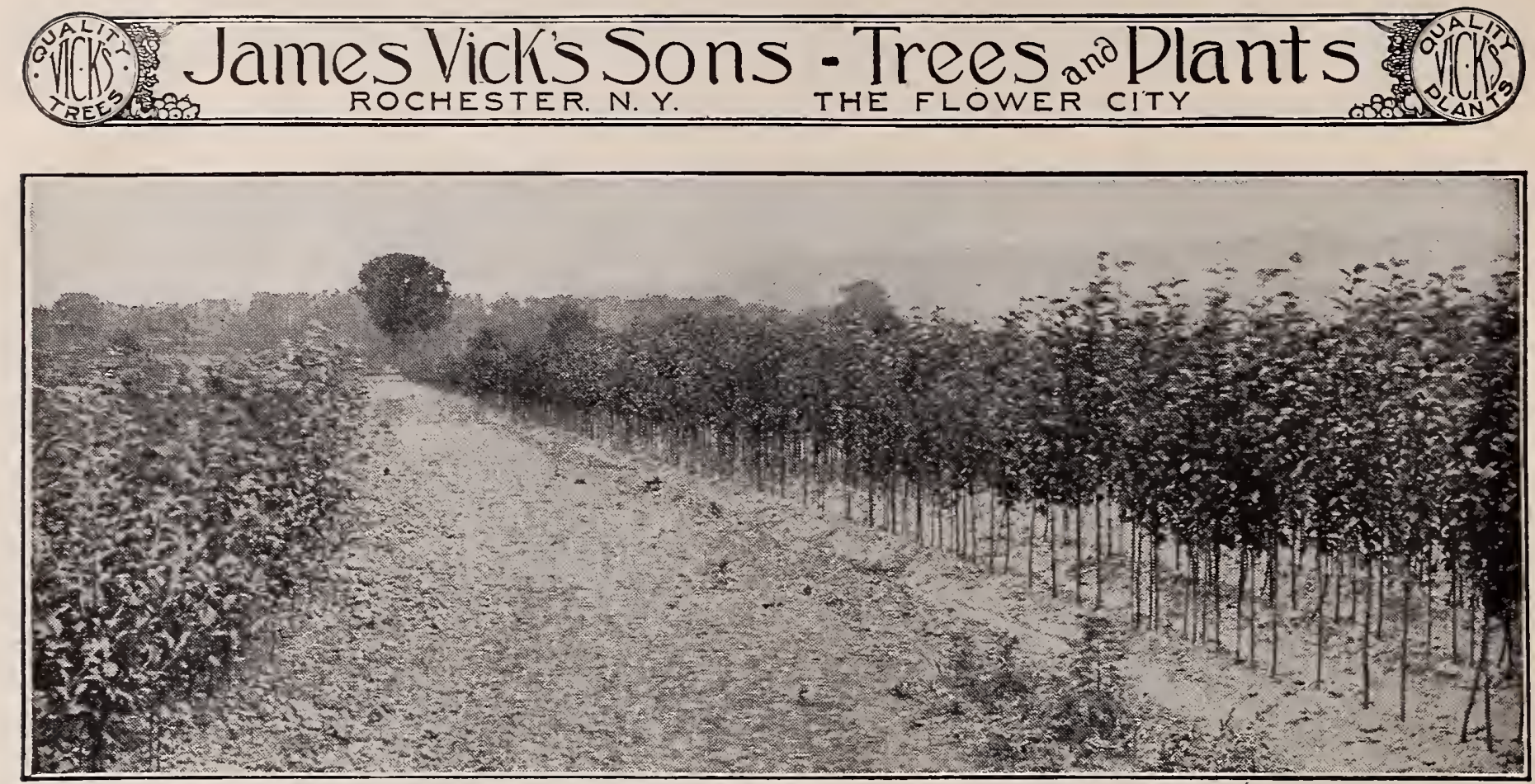

Two-Year-Old Strong, Well Rooted Trees, Ready to Dig

\section{Pears}

Pears do best in a strong loam, but succeed well in a variety of soils. Following is a list of the best varieties and the prices of each.

\section{PRICES OF PEARS}

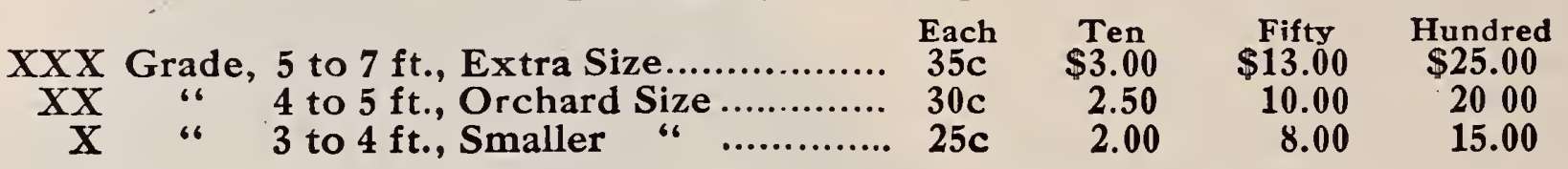

Anjou (Beurre de Anjou) (Autumn).This is one of the most popular and valuable pears one can buy. A large handsome fruit, buttery and melting with a fine vinous flavor. It is a fine keeper and will stay good until mid-winter. The tree is a vigorous grower and a good bearer. Should be picked in the latter part of October or first of November.

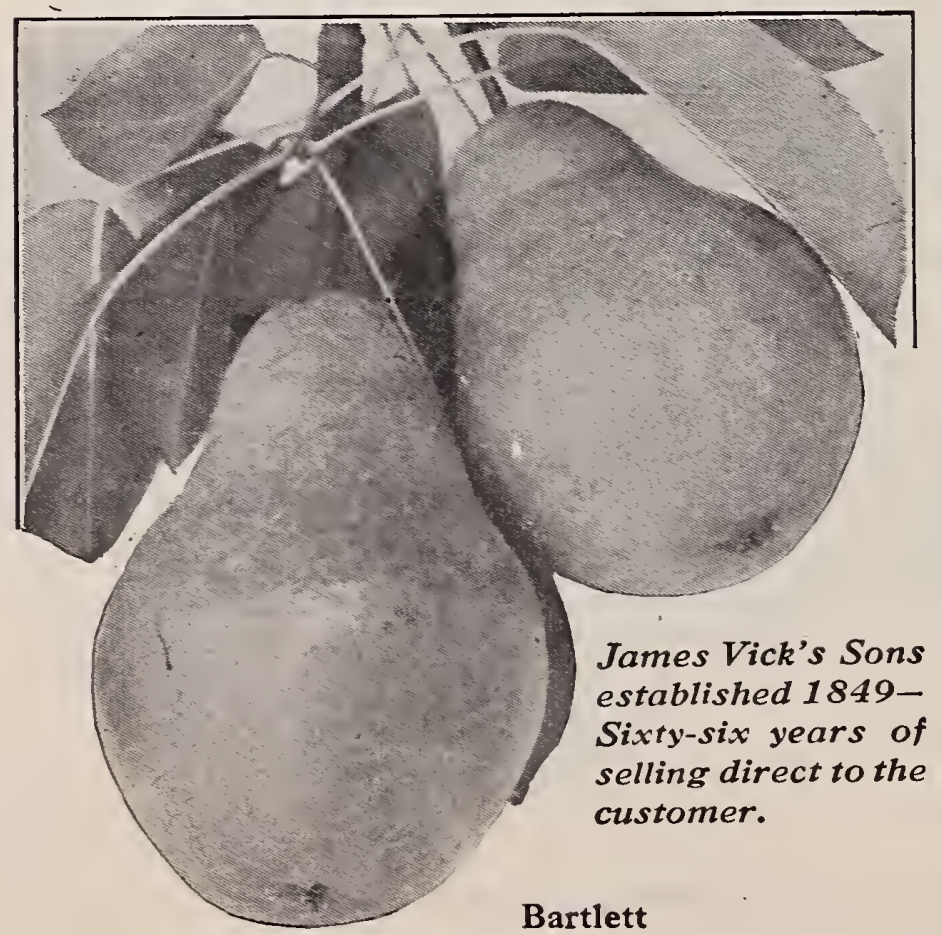

Bartlett.-Large; yellow, tinged with red; buttery and melting, with a rich, musky flavor. Bears young and abundantly. Tree vigorous and erect grower; excellent for garden or commercial orchard planting. Is the leader among canning pears, and when well grown is a universal favorite and commands top prices. Will begin to bear in three years, and in about seven years will produce a bushel of fruit per tree. Season, September.

Clapp's Favorite (Summer).-A large early variety, lemon yellow with red cheek. Flesh fine, juicy melting and buttery. Hardy, fine grower and very productive. Pick in August or September.

Duchess D'Angouleme (Autumn).-For many years this pear has been counted among the best and most profitable varieties. Excellent for export, cold storage, and for every use to which a pear can be put. Strong grower, productive, not subject to blight. Fruit large, light green patched with russet, melting, juicy, sweet and good. October and November.

Flemish Beauty (Autumn).-A large beautiful, melting, sweet pear. Tree very hardy, vigorous and fruitful. Flesh is tender, juicy and highly flavored. Season September and October. 
Lawrence.-One of the best and most valuable of Winter pears. It is above medium size, yellow color. Flesh is yellow, tender, juicy and melting. We recommend it very highly to those who want a MidWinter variety.

Kieffer (Autumn).-Large, rich yellow, tinged with red, somewhat russet. Very handsome. Flesh is white, buttery and juicy. Very valuable for canning purposes. Kieffer bears fruit when other kinds fail. Tree is a vigorous grower, early and regular bearer, extremely hardy. Immensely productive; bears young. September to November.

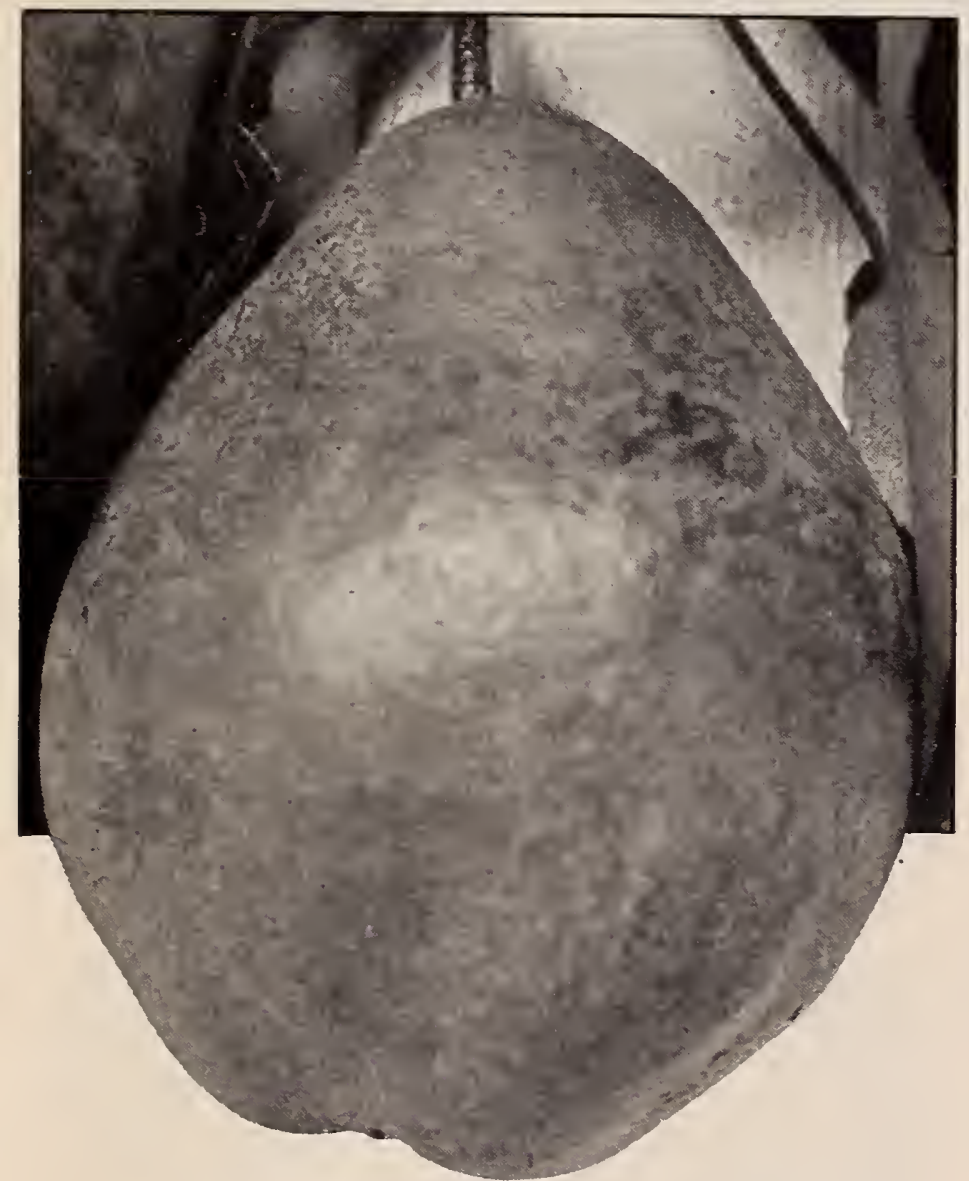

Kieffer-Hardy, Strong, Abundant Bearer

Seckel (Autumn).-Best known and most popular home garden pear. Of the richest flavor. Fruit small, yellowish brown with red cheek. Flesh juicy and melting. Very best quality.

Wilder (Summer).-A valuable early market kind. Form regular, fair size, handsome. Greenish yellow with red cheek. Flesh sweet, juicy and melting. Tree strong grower and good bearer.

\section{Dwarf Pears}

\section{On Quince Roots}

Dwarf trees are popular where the space is limited. Fruit is same size as on the standard trees.

\begin{tabular}{|c|c|c|c|}
\hline RIC & & & \\
\hline & Eac & Ten & \\
\hline & & 82 & $\$ 20$. \\
\hline
\end{tabular}

We recommend the following varieties of dwarf pear:
Duchess
Anjou
Bartlett
Seckel

\section{Apricots}

Aside from its value as a fresh fruit, the apricot has a fixed place on the list of fruits for canning and drying. Vast quantities are used in this way every year.

\section{PRICE OF APRICOT TREES 35 c Each $-\$ 3.00$ for Ten}

Alexander.-A large, oblong, orange yellow fruit, spotted with red. Flesh is sweet, juicy and very good. It is a hardy, prolific bearer and very popular in the east. One of the best of the Russian varieties. Ripens early.

Early Golden.-An American variety of apricot. Fruit is small, pale orange, juicy and sweet. The tree is hardy and prolific. Ripens first of July.

Harris.-This variety is remarkable for its size, beauty and productiveness. It is extremely hardy, will stand the severest winter. Fruit is of a rich golden color and of very fair quality. Ripens in middle of August.

Montgamet. - A pale yellow apricot, slightly tinted with red; flesh is firm, juicy and agreeably acid. A. popular variety largely grown for the market.

Moorpark.-The largest of all apricots; orange in color with a red cheek. More money is made from these than from any other variety. Flesh is firm, juicy and very fine. Moorpark ripens in August.

Don't forget that we sell Vegetables and Flower Seeds, Plants, Shrubs, Vines and Trees. Everything for the market gardener and the fruit grower.

\section{BUY DIRECT FROM JAMES VICK'S SONS}

In the Farmer's Bulletin, No. 113, of the United States Dept. of Agriculture, it says: "If the farmer makes his purchase direct from the nurserymen, he will save the expense of the middleman or agent, and is less liable to the mistakes and injuries that occur through repeated handling." 

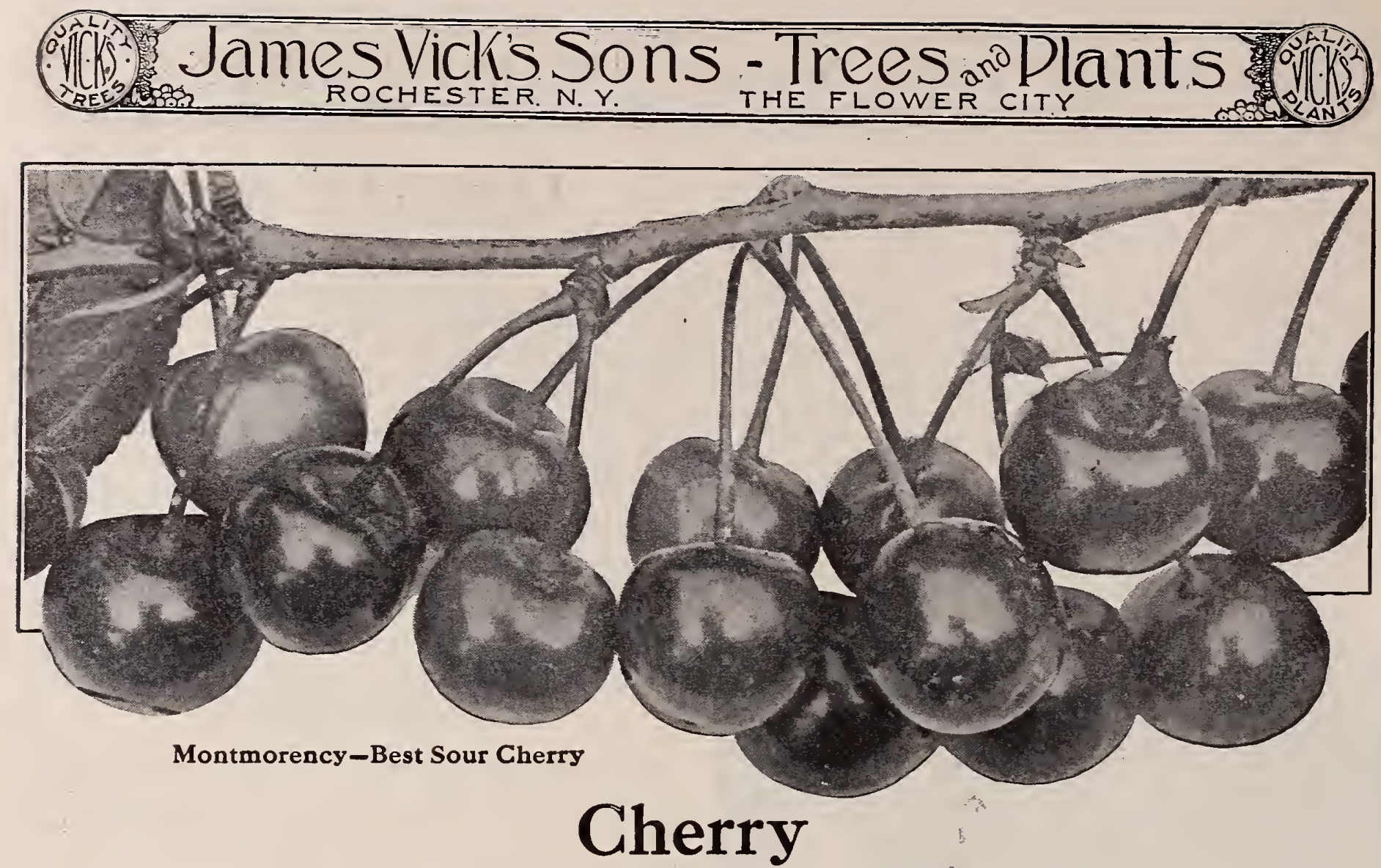

The cherry is one of the most profitable of all the fruits that are grown. The most important point is to be sure the tree is set in dry or well drained land. No other fruit is so greatly injured by too much moisture as is the cherry. We have divided our list into the Sours or Morellos and Sweets or Hearts.

\section{SOUR VARIETIES}

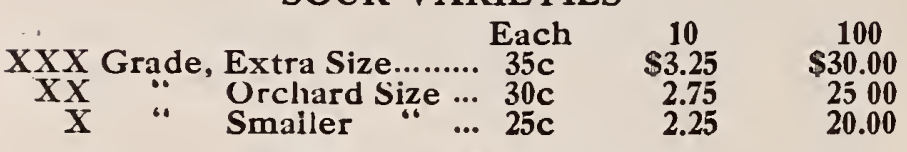

\section{SOUR CHERRIES}

Dyehouse.-One of the best Sour Cherries for market or home use. The tree is hardy, is an upright grower and always productive. The great quality of this variety is its tendency to hang on the tree after it is ripe. Several varieties that ripen later can be picked before this Dyehouse Cherry drops.

Early Richmond.-Medium size, dark red, melting and juicy, acid flavor; one of the most valuable and popular of the acid cherries and is unsurpassed for cooking; tree slender grower, exceedingly productive and very hardy; will stand the most severe weather.

English Morello.-Medium sized cherry of a very dark red color, sometimes nearly black. It is very acid in flavor, the flesh is of good quality and it makes a fine canner. Tree is a small grower with light limbs and trunk. Ripens in July.

Montmorency.-Best of all cherries. It is hardy, reliable and productive. In great demand by canning factories. More money has been made with it than with any other variety. Large, bright shining red, acid, mid-season. June.

Ostheime.-Has been tested in the severest winters of Minnesota and found to be perfectly hardy. The fruit is large and
SWEET VARIETIES

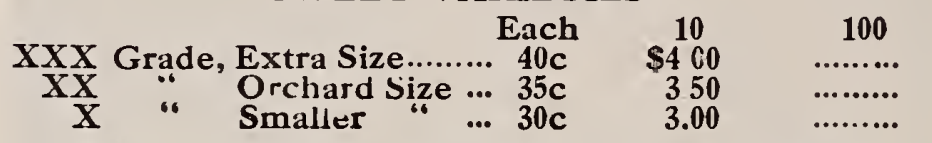

roundish. Flesh is liver colored, tender, juicy and almost sweet, although a subacid cherry. Quality is fine. Ripens about the middle of July.

\section{SWEET CHERRIES}

Black Tartarian.-This is a large, black, heart-shaped, tender, juicy, Sweet Cherry of surpassing quality. The tree is an upright, dense grower, remarkably vigorous and a regular bearer of immense crops. Fruit ripens last of June or first of July.

Bing.-This is one of the most delicious Sweet Cherries that you can grow. The tree is very hardy and vigorous and has heavy foliage. It succeeds in the East better than most sweets. Fruit is large, dark brown or black and of very fine quality.

Lambert Cherry.-One of the largest of all sweet cherries. Color dark red; flesh solid; an excellent shipper.

Governor Wood.-Very large, rich; light yellow with red cheek; juicy and sweet. One of the very best. Late in June.

Napoleon.-A magnificent cherry of the largest size; pale yellow, with a bright red cheek; very firm, juicy and sweet. Bears enormous crops; ripens late; valuable for canning. PLANT SOME IN YOUR CARDEN 


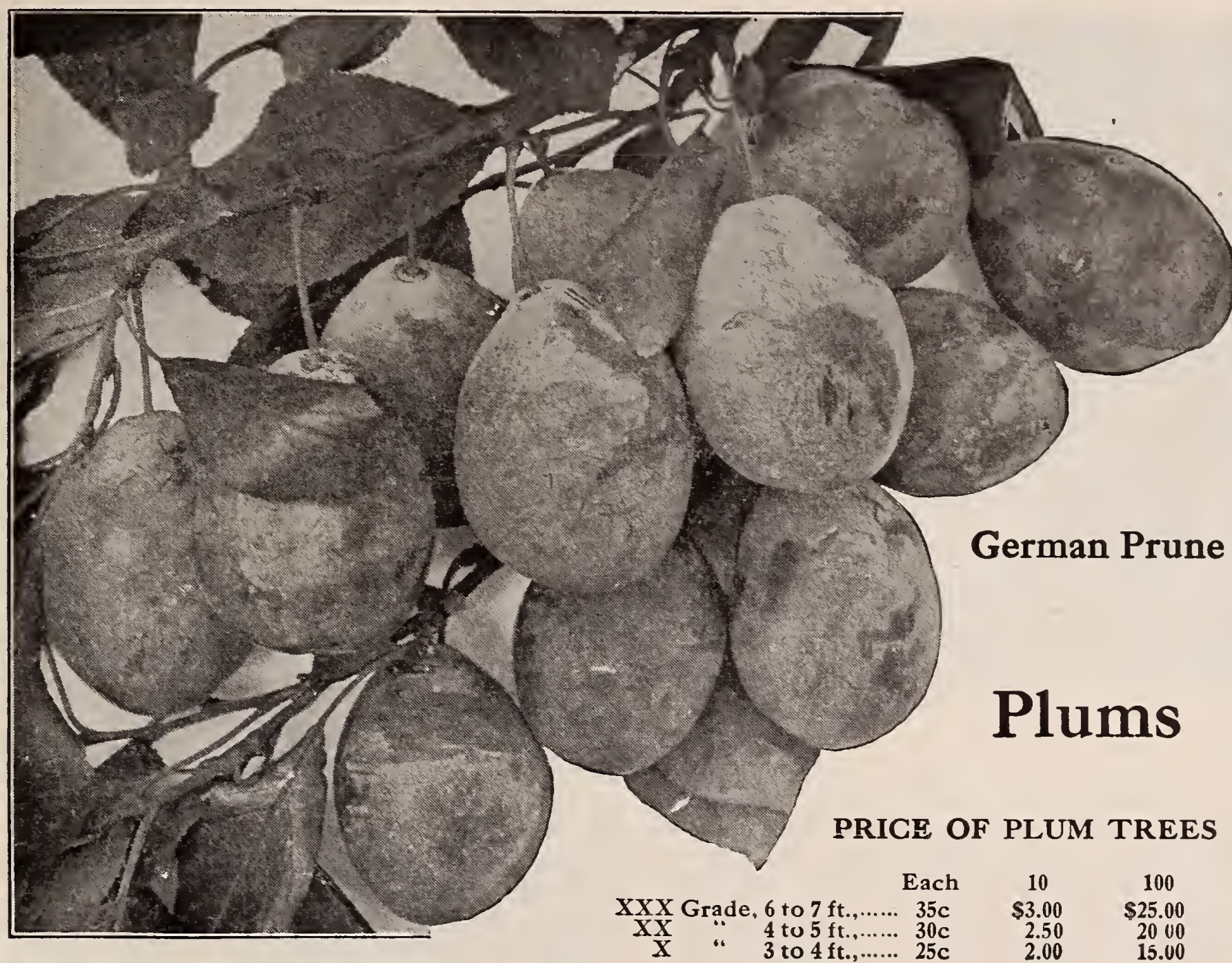

Abundance (Japan).-Large and beautiful; anber, turning to a rich, bright cherry; flcsh light ycllow, juicy, tender, sweet, excccdingly productive. Season very early.

Bradshaw.- Very large, dark violet-red, with a blue bloom; flesh yellow, juicy and good; very productive. A good seller and valuable. August 10 to 20.

Burbank (Japan).--Large and beautiful; clcar cherry rcd; an abundant bearer; valuable market variety. Ripens early in September.

German Prune.-Fruit long, oval, purple with a thick bloom; flesh firm, sweet and plcasant, separating freely from the stone; moderate growth. A great favorite. A surc market for all you have to sell at very profitable prices. September.

Gucii.-Fruit very large, deep bluish-purple covered with thick bloom. The flesh is ycllowish, swect and pleasant. The tree is hardy and a rapid grower. Ripens first wcck in Scptember.

Lombard Plum.-Lombard is a great favorite. The tree adapts itself to any locality. Hardy, producing good crops where many others will not grow; it is excecdingly productive. It is a handsome reddish plum, flesh ycllow, juicy and plcasant. An exccllent varicty, and should be planted in tll gardens and orchards.
Red June (Japan).-A vigorous, hardy, upright spreading tree, as productive as Abundance; fruit medium to large, deep vermilion-red, with handsome bloom, very showy; flesh light lemon-yellow, slightly subacid, of good and pleasant quality; half cling; pit small. Of immense value for its very early ripening.

Reine Claude (Bavay's Green Gage).Very large, greenish, fine flavor. Not surpassed in quality, beauty or size. Scptember.

Shipper's Pride.-Large, dark purple, very showy, often measuring two inches in diameter; fine, juicy and sweet. A beautiful and valuable variety. September.

Shropshire Damson.-An English variety of plum and very fine for preserving. It is a roundish blue fruit and always sells wcll; the tree is hardy and very prolific. Fruit ripens in October.

Wickson.-Very large, glowing carmine, with a heavy white bloom; flesh firm, sugary, delicious; stone small.

York State Prune.-A large size prune of dark blue color, covered with purple blush; flesh is yellow and delicious; freestone. Ripens last week in September. A valuable prune both for home and commercial use. 

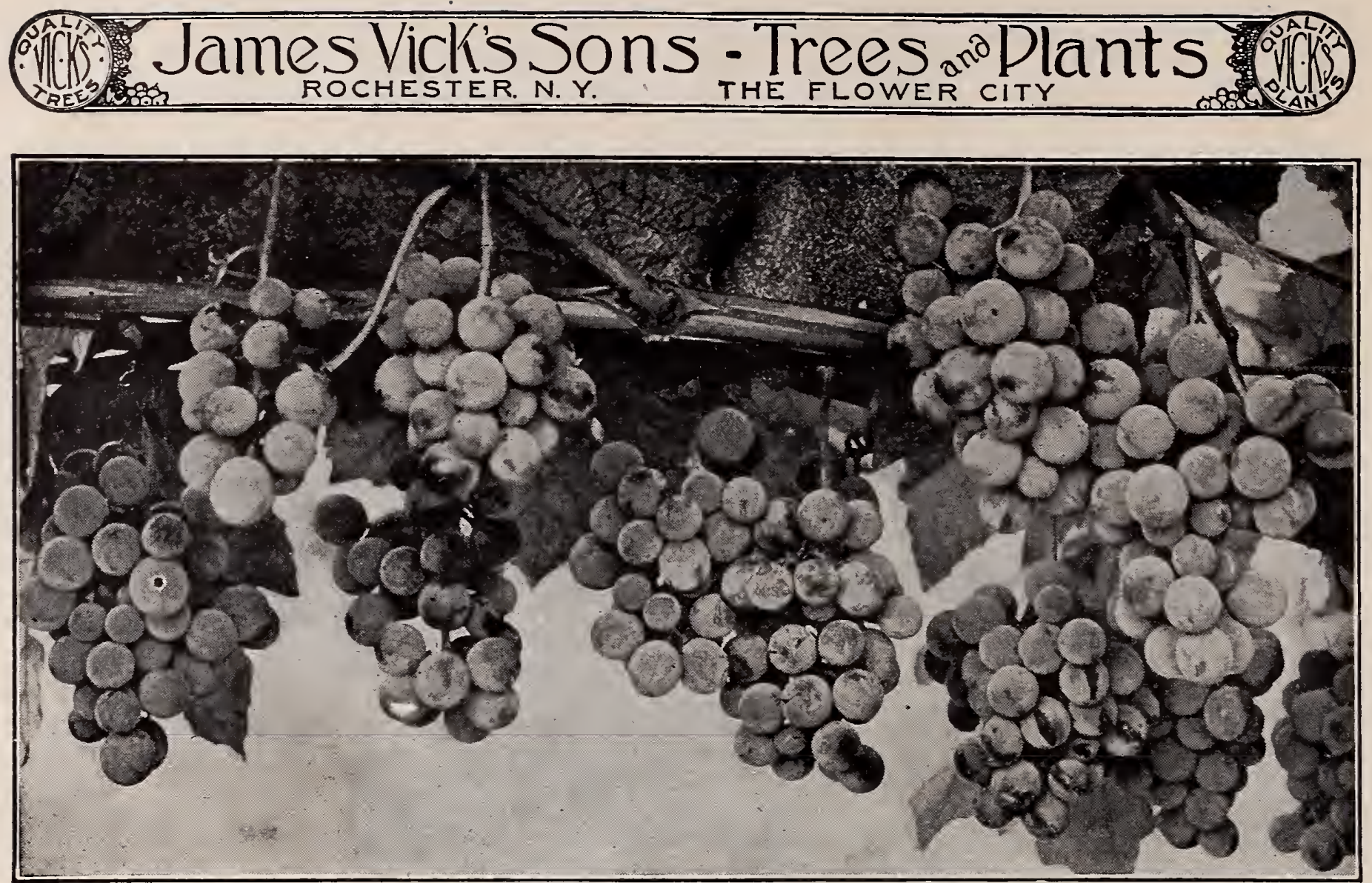

Concord-The Most Popular Grape in America

\section{Grapes}

The grape is the most healthful of all fruits, and the most highly esteemed for its many uses. It can be grown by everyone who has a garden, a yard, or a wall. It can be confined to a stake, bound to a trellis, trained over an arbor, or extended until it covers a large tree or builaing, and still it yields its graceful bunches of luscious fruit.

Campbell's Early. - Strong, vigorous, hardy vine; thick, healthy, mildew-resisting foliage; always setting its fruit well and bearing abundantly. Berries large; black, with light purple bloom. Flavor rich, sweet, slightly vinous. Very early. Strong 2 year -25 cts. each, $\$ 2.25$ for $10, \$ 20.00$ for 100 .

Niagara (White).-Bunch very large and handsome, often shouldered, compact; berries large, round; skin thin, tough, does not crack and carries well; has not much pulp when fully ripe, melting sweet. Should be in every garden. Strong 2 year-20 cts. each, 30 cts. for $2, \$ 1.00$ for $10, \$ 5.00$ for 100 .

Brighton.-A large, delicious, sweet red grape; vine thrifty and a strong grower; flesh sweet, tender and very juicy. Best of all large red grapes. First of September. Strong 2 year -15 cts. each, $\$ 1.00$ for 10 , $\$ 6.00$ for 100 .

Concord (Black).-Bunch large, shouldered, compact, berries large, covered with a rich bloom; skin tender, but sufficiently firm to carry well to distant markets; flesh juicy, sweet pulp, tender; vine a strong grower, very hardy, healthy and productive. Strong 2 year $-10 \mathrm{cts}$. each, 3 for $25 \mathrm{cts}$, $80 \mathrm{cts}$. for $10, \$ 5.00$ for $100, \$ 35.00$ for 1,000 .

Delaware.-Bunches small and compact; berries small round, thin skinned, light red. Flesh very juicy, with an exceedingly sweet and delicious flavor. Vine hardy and productive. Strong 2 year -15 cts. each, $\$ 1.25$ for $10, \$ 7.00$ for 100 .
Salem.-Bunch large and compact; berry large, of a light chestnut or Catawba color; thick skinned, perfectly free from hard pulp; very sweet and sprightly, with a most exquisite aromatic flavor; as early as Delaware. Strong 2 year-20 cts. each, $50 \mathrm{cts}$. for $3, \$ 1.00$ for $10, \$ 5.00$ for 100 .

Worden.-Said to be a seedling of the Concord. Bunch large, compact, handsome; berries large-larger than those of the Concord. It ripens a few days earlier, and is superior to it in flavor. Destined to become very popular for the vineyard and garden. Strong 2 year $-15 \mathrm{cts}$. each, $25 \mathrm{cts}$. for $2, \$ 1.00$ for $10, \$ 6.00$ for 100 .

Diamond.-Bunch large, compact; berry medium size; color greenish white with a yellow tinge; flesh juicy and almost without pulp; very good. Vine vigorous and productive. Strong 2 year $-20 \mathrm{cts}$. each, $\$ 1.00$ for $10, \$ 6.00$ for 100 .

Moore's Early. - Bunch large, berry round; color black, with a heavy blue bloom; quality better than the Concord. Vine exceedingly hardy; has been exposed to a temperature of more than 20 degrees below zero without injury, and is entirely exempt from mildew or disease. Its earliness makes it desirable for an early crop, maturing as it does ten days before the Hartford, and twenty before the Concord. Strong 2 year $-20 \mathrm{cts}$. each, $50 \mathrm{cts}$. for 3 , $\$ 1.50$ for $10, \$ 7.50$ for 100 . 


\section{Currants}

\section{All of Our Plants are Strong Two-Year-Olds that Are Sure to Please You}

Plant in very fertile soil made so by a liberal use of fertilizer. The tops should be cut back to three or four branches. Thin old wood out every year. Currant worms can be destroyed by sprinkling with water in which white Hellebore is stirred. (One oz. to 3 gallons.) Plant in rows five feet apart, and three feet in the row.

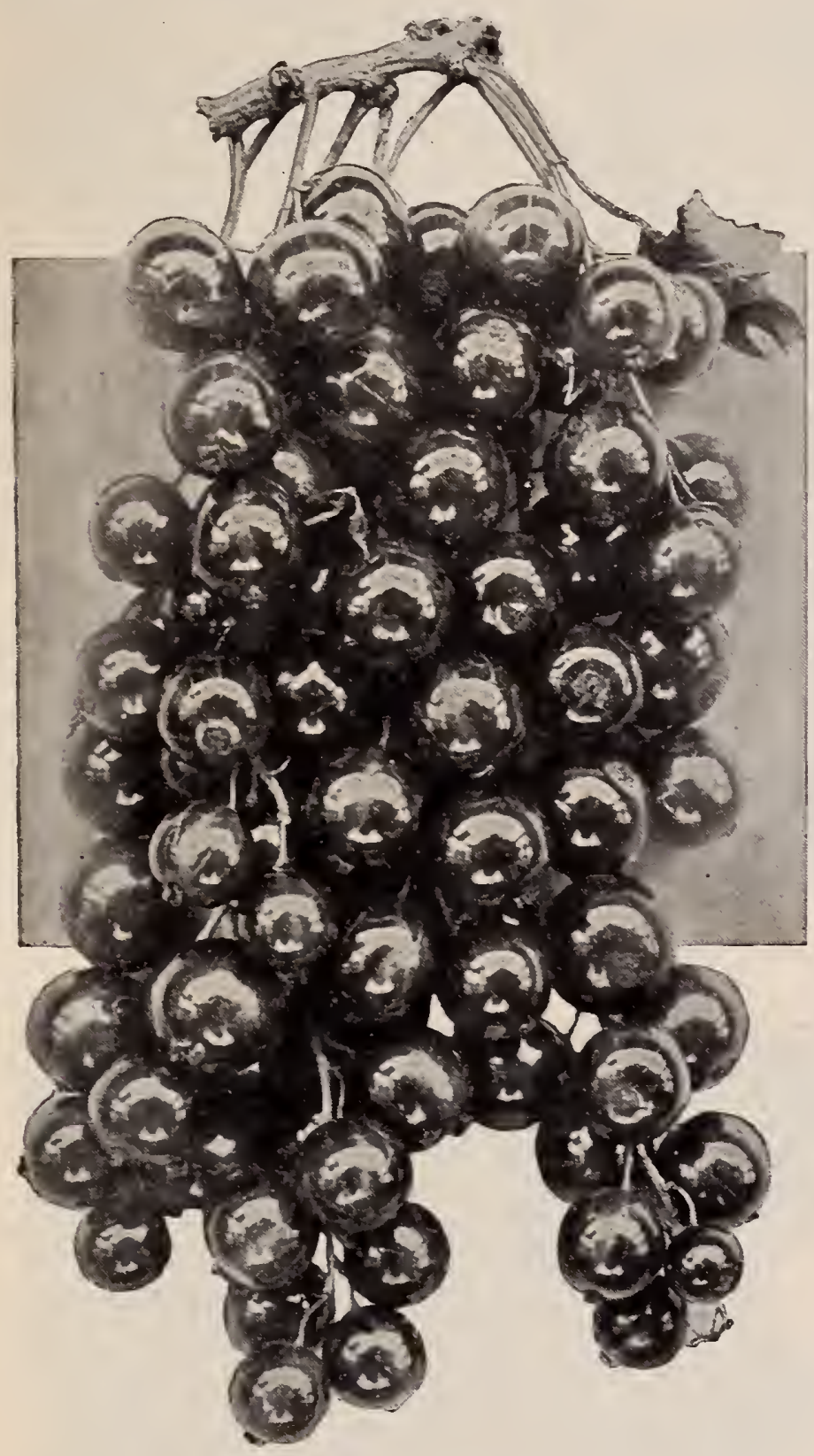

Red Cross

Red Cross.-Sweetest currant ever produced. In making jellies requires only half the amount of sugar others do. Large clusters of great, big berries. We recommend it to all of our customers.

Price-15 cts. each, $\$ 1.00$ for $10, \$ 6.50$ for $100, \$ 50.00$ for 1,000 .

Perfection.-A large red currant, mild, subacid flavor. Plenty of pulp and few seeds. Less acid and of better quality than any other currant. Very productive. Endorsed by N. Y. State Experimental station. Winner of Barry Gold Medal, Pan American Exposition Medal and St. Louis Exposition Gold Medal. Price-20 cts. each, $\$ 1.75$ for $10, \$ 15.00$ for 100 .

Cherry.-Large red berries, borne in fairlength clusters. A robust, fruitful and standard variety that we believe has been set more largely in commercial orchards than any other sort. Price-10 cts. each, 80 cts. for $10, \$ 6.00$ for $100, \$ 45.00$ for 1,000 .

Wilder.-It is one of the strongest growers and very productive. Bunches of berries very large, bright, attractive red color, and hang on bushes longer than any other variety. Price-10 cts. each, $80 \mathrm{cts}$. for 10 , $\$ 6.00$ for $100, \$ 45.00$ for 1,000 .

Fay's Prolific.-Large; red; long bunches. Exceedingly productive. The fruit is of fine quality. Price-10 cts. each, 80 cts. for 10 , $\$ 6.00$ for $100, \$ 45.00$ for 1,000 .

White Grape. - Very large, yellowish white; mild acid; fine for the table. Has a low, spreading habit and dark green foliage. The finest of the white kind; very productive. Price-15 cts. each, $\$ 1.00$ for 10 , $\$ 6.50$ for $100, \$ 55.00$ for 1,000 .

Black Champion. - Bushes large and flavor of fruit particularly delicious. It hangs low on the bunches, and unlike other varieties, bears the severest pruning without detriment. Price-15 cts. each, $\$ 1.00$ for $10, \$ 6.50$ for $100, \$ 55.00$ for 1,000 .

\section{THE PARGEL POST}

can be used by our customers. We will prepay postage charges on berry plants, etc.. if you wish. See this list :

Gooseberry Plants sent by mail.........................add $3 \mathrm{c}$ per plant

Grape Vines

Currant

Raspberry

Blackberry add $3 \mathrm{c}$ "

add $20 \mathrm{c}$ to price per 10

add 10c " "

add $10 \mathrm{c}$ “ 

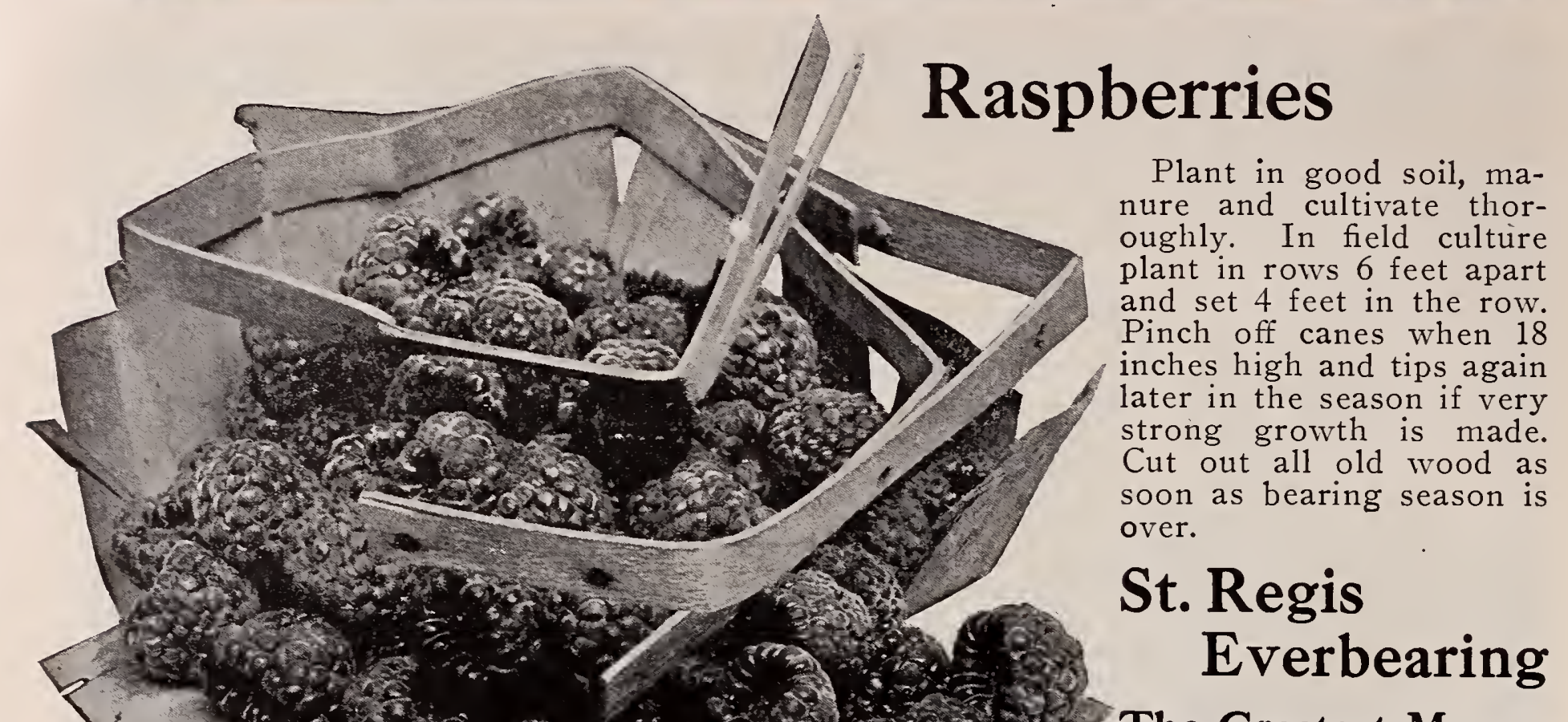

\section{St. Regis} Everbearing

\section{The Greatest Money} Maker of Them All

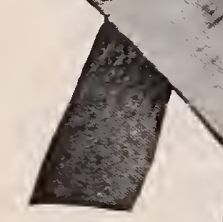
thity

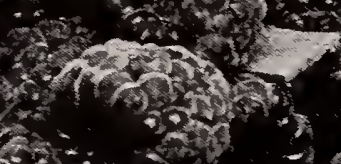

\section{ST. REGIS}

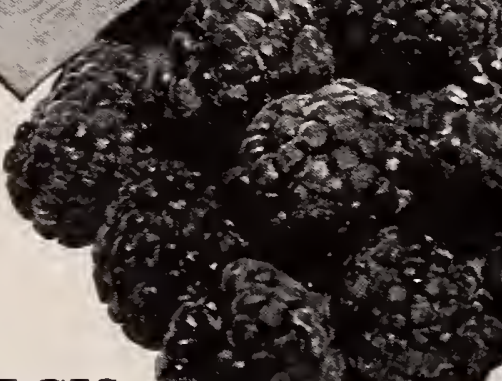

Cuthbert.-The hardy red kind that gives everyone satisfaction; it thrives everywhere. Fruit large, bright red; good quality. Very productive, a great money maker. Price-50 cts. for $10, \$ 1.50$ for 100 , $\$ 12.00$ for 1,000 .

Herbert.-This is a new red raspberry which originated in Canada and is very highly recommended by the Government Experiment Station at Ottawa on account of its unusual hardiness. Price-10 cts. each, 80 cts. for 10 , $\$ 3.50$ for 100 .

Columbian.-Very large, often an inch in diameter; dark red, bordering on purple, adheres firmly to stem and will dry on the bush if not picked; of rich, sprightly flavor, the best for canning or evaporating, and probably the most productive of all raspberries. It propagates from the tips and never suckers from the roots. It is very hardy, enduring $28^{\circ}$ below zero without injury. Prices $50 \mathrm{cts}$. for $10, \$ 2.00$ for $100, \$ 15.00$ for 1,000 .

A large, firm, red berry of the highest quality. Strong growing and very productive. Does well in any soil and bears fruit the first year. Very hardy and succeeds where others fail. St. Regis bears the highest quality fruit through July, August, September and October. Price-10 cts. each, 75 cts.
for $10, \$ 3.00$ for $100, \$ 25.00$ for 1,000 .

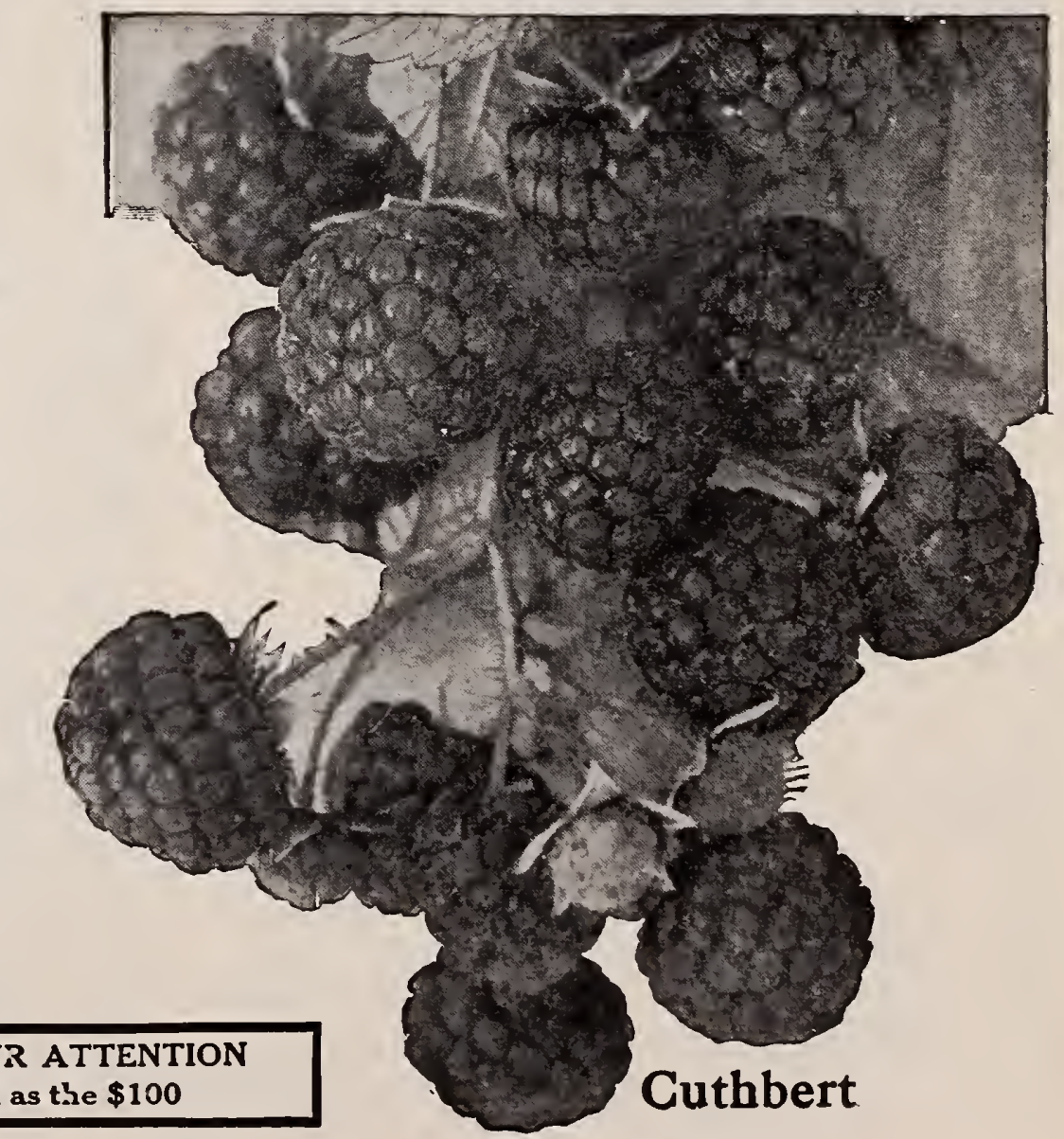



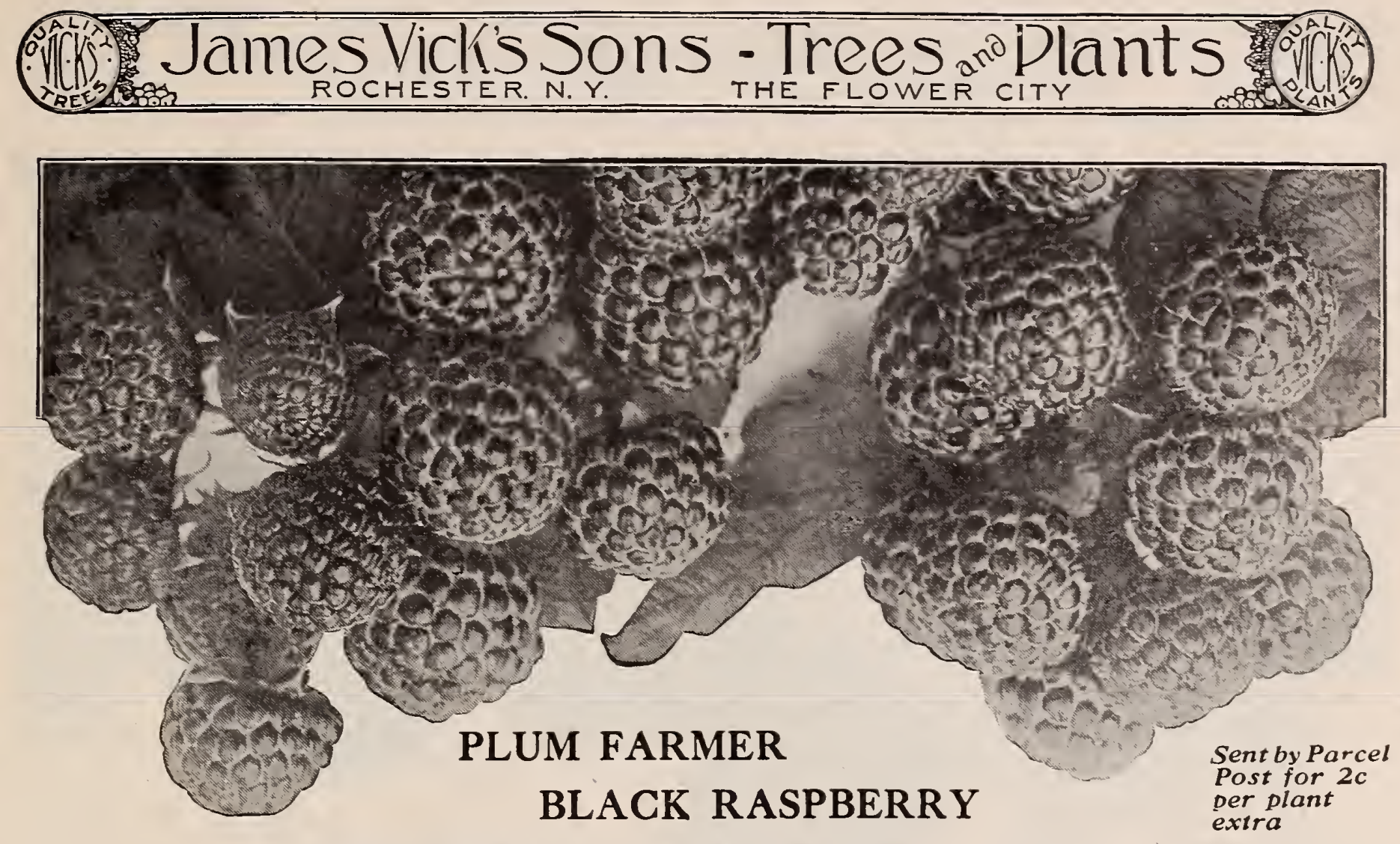

THE BEST FOR THE HOME AND MARKET

Plum Farmer.-The Plum Farmer Black Raspberry is, in our estimation, the best Blackcap for home and market ever introduced. It ripens early. Berries are very large, thick meated, juicy and sweet. They pick very easily, and stand up and carry weli. In quality, firmness and productiveness, it is all that can be desired either by wholesale growers or for the home garden.

"The plants are hardy, vigorous and productive: the berries large, good in color and quality. It has already been grown in some localities, and reports of its behavior are very favorable. It certainly should be given a trial in all commercial plantations."-Report of Geneva Experimental Station.

Price-25 cts. for 3,60 cts. for $10, \$ 2.00$ for $100, \$ 15.00$ for 1,000 .

Cumberland. - A mammoth, excellentquality, mid-season blackcap that loads its stocky canes with handsome, glossy berries. It is extremely hardy; rain or drought affect the plants but little. Price-25 cts. for $3,60 \mathrm{cts}$. for $10, \$ 2.00$ for $100, \$ 15.00$ for 1,000 .

Gregg.-A large showy blackcap of first quality. A strong grower, hardy and very productive. Price-25 cts. for 3, $60 \mathrm{cts}$. for $10, \$ 2.00$ for $100, \$ 15.00$ for 1,000 .

Kansas.-Largest size, strong, vigorous grower, hardy, bearing immense crops. Size of Gregg. Brings highest price on the market. Price-25 cts. for 3,60 cts. for 10 , $\$ 2.00$ for $100, \$ 15.00$ for 1,000 .
Black Diamond.-One of the best for home and market use. For drying and evaporating it excels all others. The fruit is large and handsome, and on account of its good size, good keeping qualities and its productiveness, is one of the most profitable to grow. Very sweet and excellent. Price-25 cts. for $3,60 \mathrm{cts}$. for $10, \$ 2.00$ for $100, \$ 15.00$ for 1,000 .

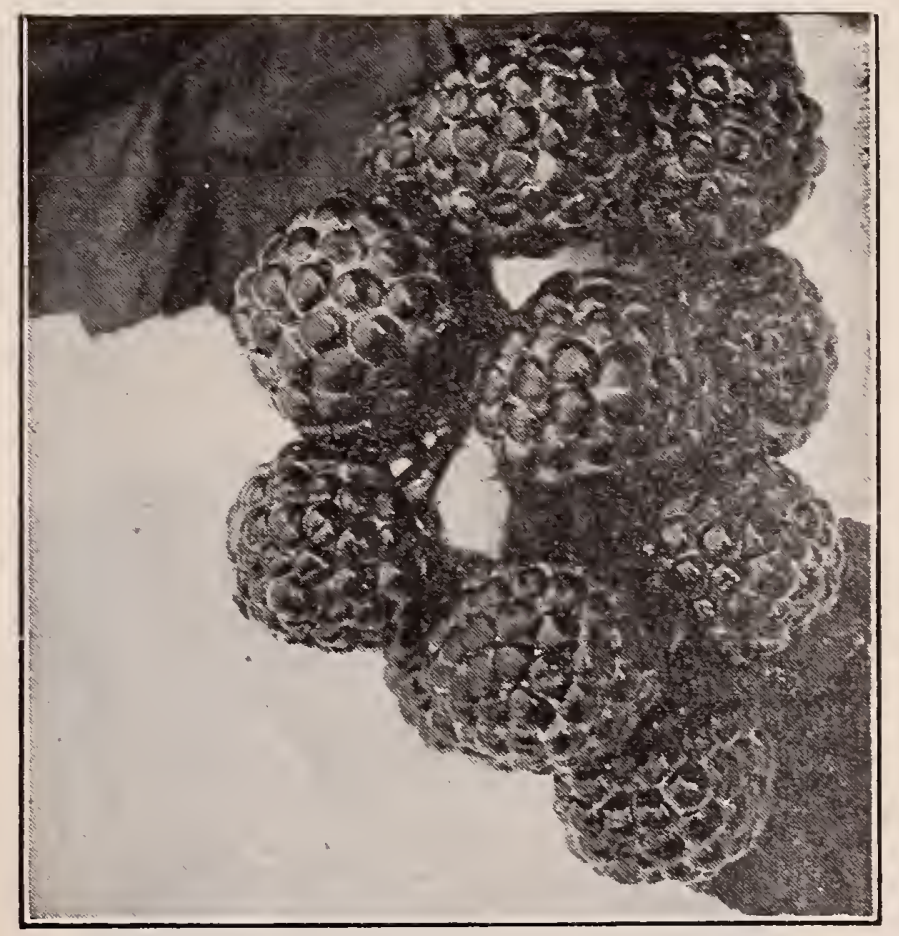

Kansas

BERRY BUSHES, CURRANTS AND GRAPES can he sent to you by Parcel Post for an extra charge of 2c per plant. "VICK QUALITY" the best the earth produces-SEEDS, PLANTS, BULBS, TREES. 


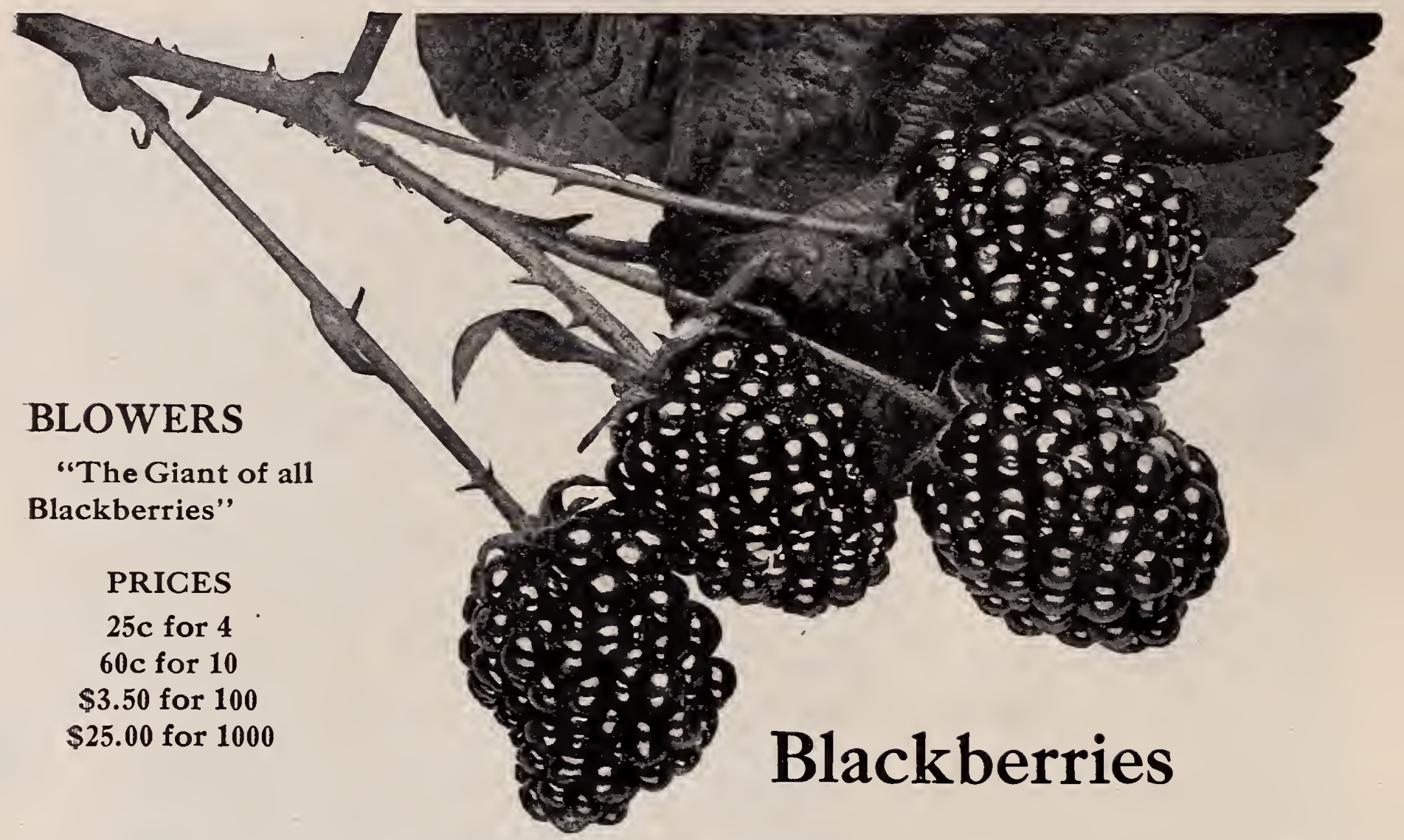

Blowers.-Rightly called the giant of all blackberries. An upright mammoth grower, is very hardy and productive. The fruit is jet black, of fine quality and a good shipper. Commences to ripen in July and bears fruit about two months.

Eldorado.-A berry you can depend on every time. The vines are very vigorous and extra hardy. Berries are large, black and borne in big clusters. Price-25 cts. for 4,60 cts. for $10, \$ 3.00$ for $100, \$ 20.00$ for 1,000 .

Rathbun.-Fruit black, luscious, of the highest quality, with a high polish and suf- ficiently firm to carry well. A large proportion of the berries will measure from $11 / 2$ to $13 / 4$ inches in length. The flesh is juicy, high-flavored, soft throughout, without any hard core, sweet and delicious. Cannot be surpassed for the table or canning. The plant is a strong, erect grower, and unlike most varieties, produces few suckers, but roots from tips like raspberries. It is hardy, having sustained a temperature of 15 to 18 degrees below zero without harm; vigorous, great bearer. By mid-summer pruning it can be trained in tree form. Price-25 cts for $4,50 \mathrm{cts}$. for $10, \$ 3.00$ for $100, \$ 19.00$ for 1,000 .

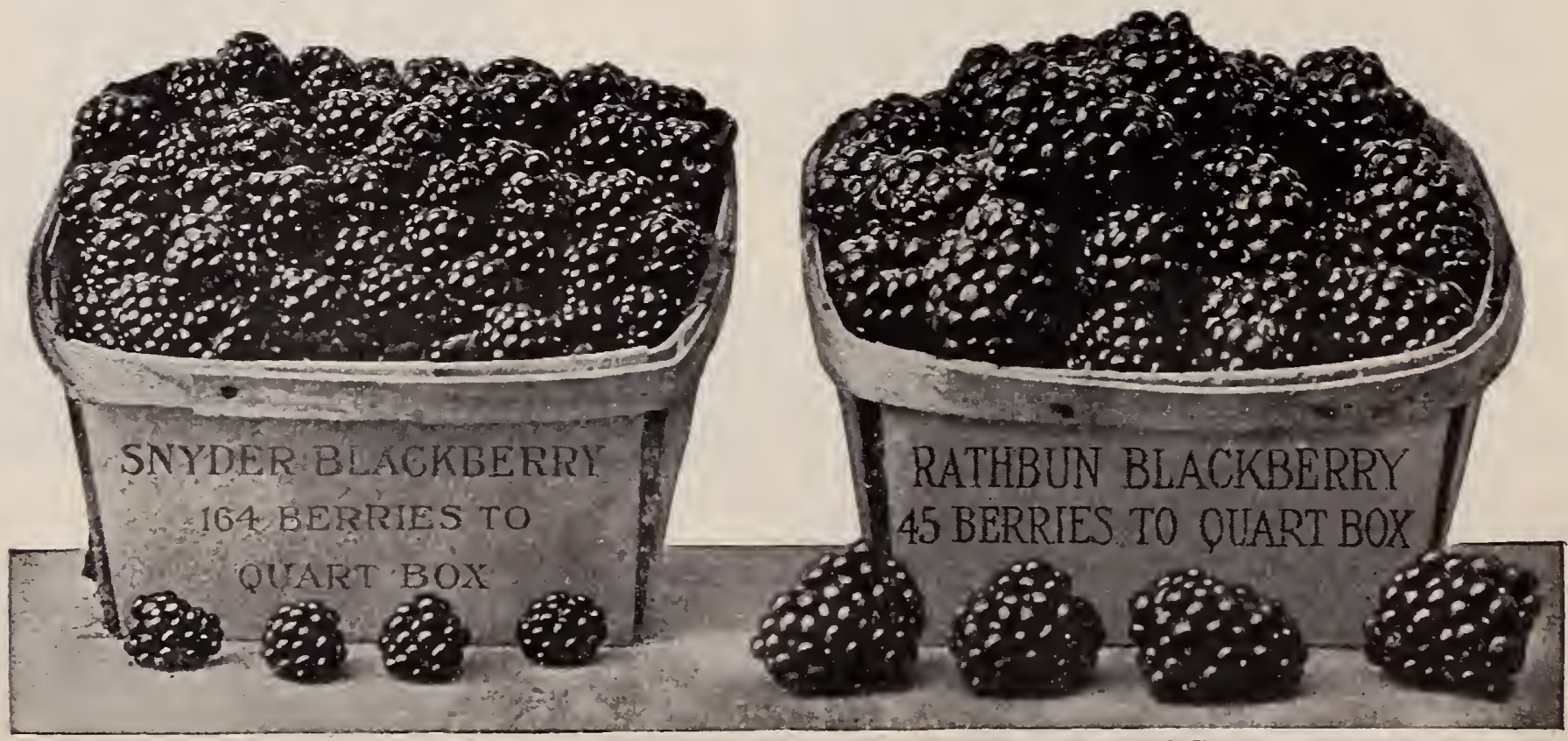



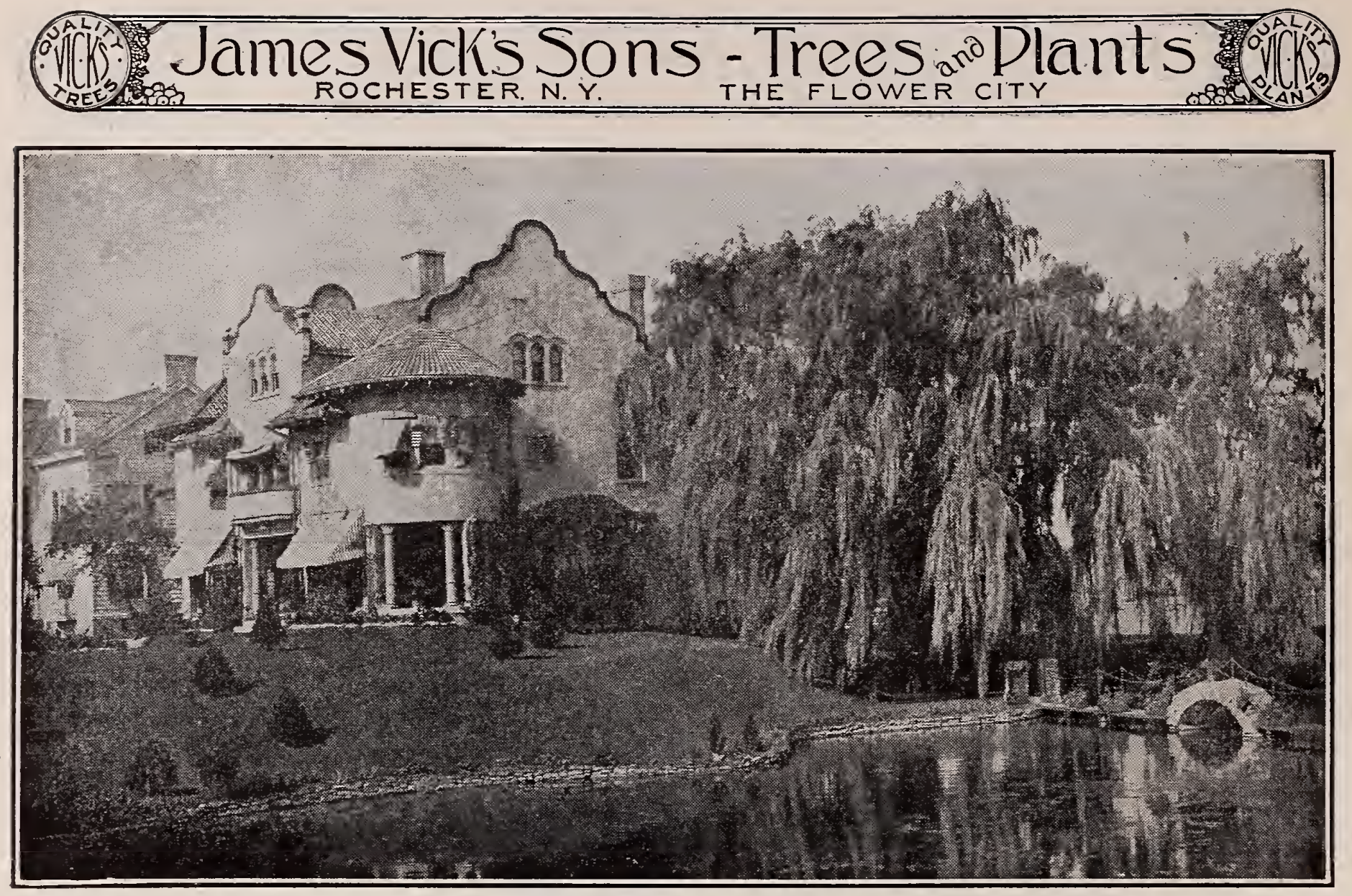

\section{Ornamental Trees}

For City Streets.-Sugar Maple, Norway Maple, American Elm, American Ash, American Linden, Oriental Plane.

Rapid Growing Street Trees.-Silver Maple, Ash-leaf Maple, Carolina Poplar.

Best Lawn Trees.-Norway Maple, Schwedler's Maple, Cut-leaf Weeping Birch, Catalpa Speciosa, Purple-leaf Beech, Tulip Tree, American Mountain Ash, the Oaks, English Elm, the Lindens.

Low Growing Lawn Trees.-Japan Maple, Catalpa Bungeii, Japan Weeping and Flowering Cherries, the Dogwoods, Double Flowering Thorns, Magnolias, Weeping Mulberry, Bechtel's Flowering Crab.

Trees for Screens.-Carolina and Lombardy Poplar, White Flowering Dogwood.

Ash, American.-A well known native
A tree of largest size. Thrives in any soil,
suitable for street or avenue. Price-6 to $8 \mathrm{ft}$., $50 \mathrm{cts}$; 8 to $10 \mathrm{ft} ., 75 \mathrm{cts}$. each.

Beech, European.-A compact tree attaining the largest size, retains its leaves brown and dry throughout the winter. Price-5 to $6 \mathrm{ft}$., $\$ 1.50 ; 6$ to $8 \mathrm{ft}$., $\$ 2.00$ each.

Beech, European Weeping.-A strong growing variety with a fairly straight or upright trunk from which spread straggling and crooked branches; foliage rich, large and glossy. Price-6 to $8 \mathrm{ft}$., $\$ 2.00$ each.

'Beech, River's Purple-Leaved.-A variety of European beech with large, smooth, very dark leaves. The best purple lawn tree known. Price-3 to $4 \mathrm{ft}$., $\$ 1.00 ; 4$ to $5 \mathrm{ft}$., $\$ 1.75$ each.

Birch, Cut-Leaf Weeping.-Its tall, slender, yet vigorous growth, graceful, drooping habit, silvery-white bark and delicately cut foliage present a combination of attractive characteristics rarely met with in a single tree. Price-5 to $6 \mathrm{ft}$., $90 \mathrm{cts}$. each.

Catalpa, Speciosa (Hardy or Western Catalpa).-A variety which originated in

the West but which has become very popular throughout the country on account of its hardy nature. The trunks are straight and smooth, hence particularly adapted to forest planting, as its wood has been found to be very desirable for fence posts, railroad ties, etc. It is the most popular of the Catalpas for street and park planting. It has immense leaves, velvet brown when they first appear, changing to rich dark green; followed by immense panicles of pink and white flowers.

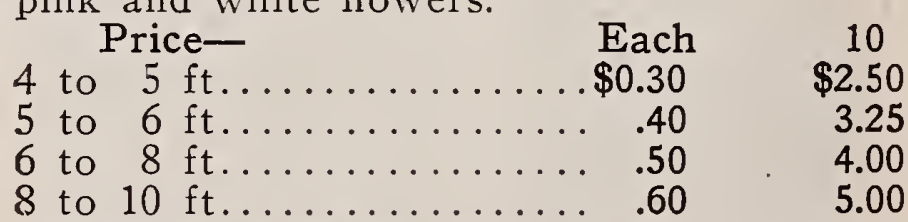

Catalpa Bungeii (Umbrella Catalpa).Grafted on stems 6 to $8 \mathrm{ft}$. high, it makes an umbrella shaped top without pruning; perfectly hardy, and flourishes in almost all soils and climates; leaves large, glossy, heart-shaped, deep green; always making a symmetrical head. One of the most unique trees; desirable for lawn, park and cemetery planting. Two-year trees, extra large, $\$ 1.00$ each. 


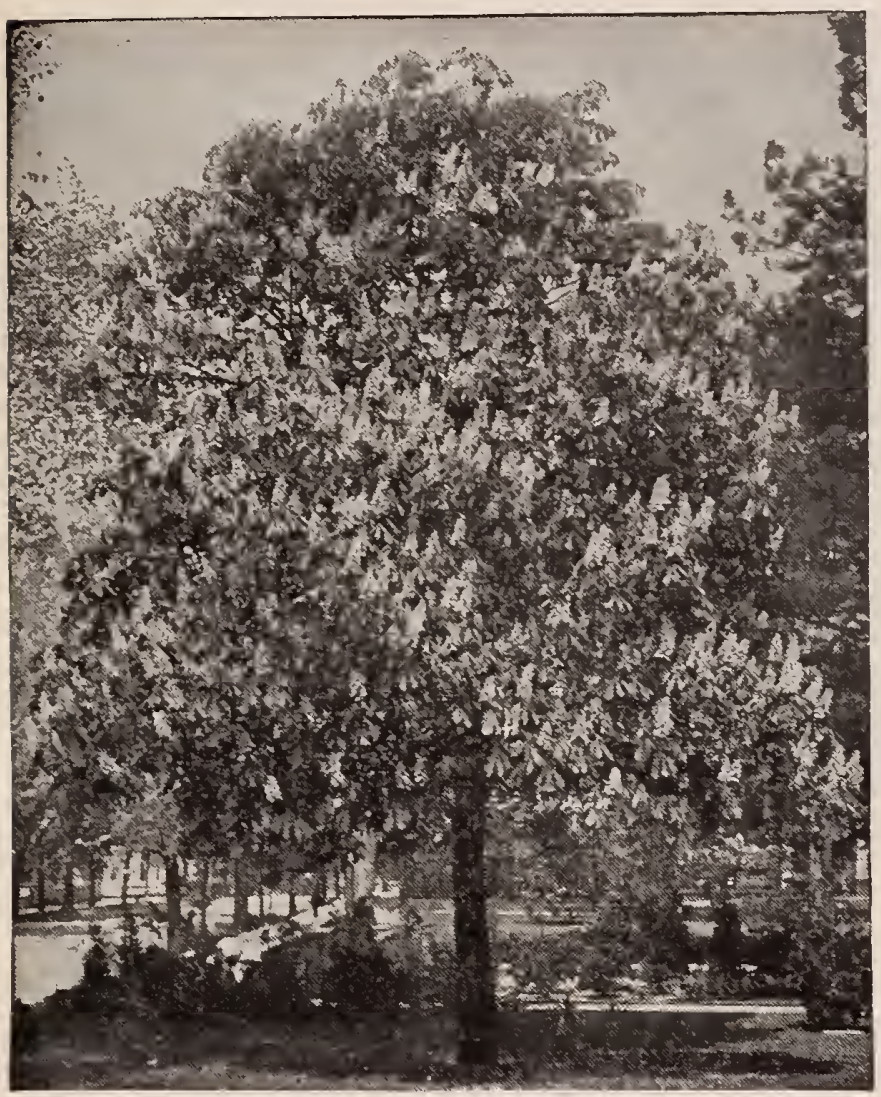

White Flowering Chestnut

Chestnut, Double White Flowered.-A beautiful well-known tree of roundish form with dark green foliage and abundance of spikes of white flowers, slightly marked with red. Hardy. 4 to $5 \mathrm{ft}$., $\$ 1.00$ each.

American Sweet.-A valuable native tree, both useful and ornamental. When grown in open ground it assumes an elegant, symmetrical form; foliage rich and glossy. Nuts sweet, of delicate flavor, and are a valuable article of commerce. 4 to $5 \mathrm{ft}$., 50 cts. each; $\$ 4.50$ for 10 .

Spanish.-A handsome, round headed tree, producing abundantly very large nuts that find a ready market at good prices. Not as sweet as the American. 4 to $5 \mathrm{ft}$., 50 cts. each; $\$ 4.50$ for 10 .

Japan or Giant Chestnut.-Of the very many good things from Japan, none is more worthy than this. Decidedly ornamental, hardy and productive; of dwarf habit, bearing extremely young; nuts enormous size. 4 to $5 \mathrm{ft}$., 60 cts. each; $\$ 5.00$ for 10 .

Butternut.-Valued for its tropical appearance and beautiful wood, as well as for its nuts. Produces large, handsome, elongated nuts with rich, sweet, oily kernel; very nutritious. The tree grows rapidly and yields large crops in a few years. There are large profits in butternut growing. A small outlay will bring large returns as soon as the trees begin to bear. 5 ot $7 \mathrm{ft}$., $50 \mathrm{cts}$. each.

\section{Seeds, Bulbs, Shrubs, listed in our Garden and Floral Guide}

Crab, Bechtel's Double Flowering.-One of the most beautiful of the many fine varieties of flowering crabs. Tree of medium size, covered in early spring with large, beautiful, double, fragrant flowers of a delicate pink color. From a distance the flowers have the appearance of small roses. Blooms when quite young. 3 to $4 \mathrm{ft}$., 75 cts. each.

Cherry, Double Flowering.-A tree of medium growth, producing clusters of double white flowers in May. Blooms so profusely as to completely hide the branches from view. 3 to $4 \mathrm{ft}$., $60 \mathrm{cts}$. each.

Dogwood, Red Flowering.-A valuable variety producing beautiful carmine flowers; of great value. Price, $\$ 1.50$.

Dogwood, White Flowering.-A fine American tree, growing from sixteen to twenty-five feet high. Foliage of a grayish green color; very glossy and handsome, turning in the autumn to a deep red, rendering the tree one of the most beautiful objects at that season. The flowers appear before the leaves in the spring and are about three inches in diameter; white and very showy. It is one of the most valuable ornamental trees. Price, $\$ 1.00$.

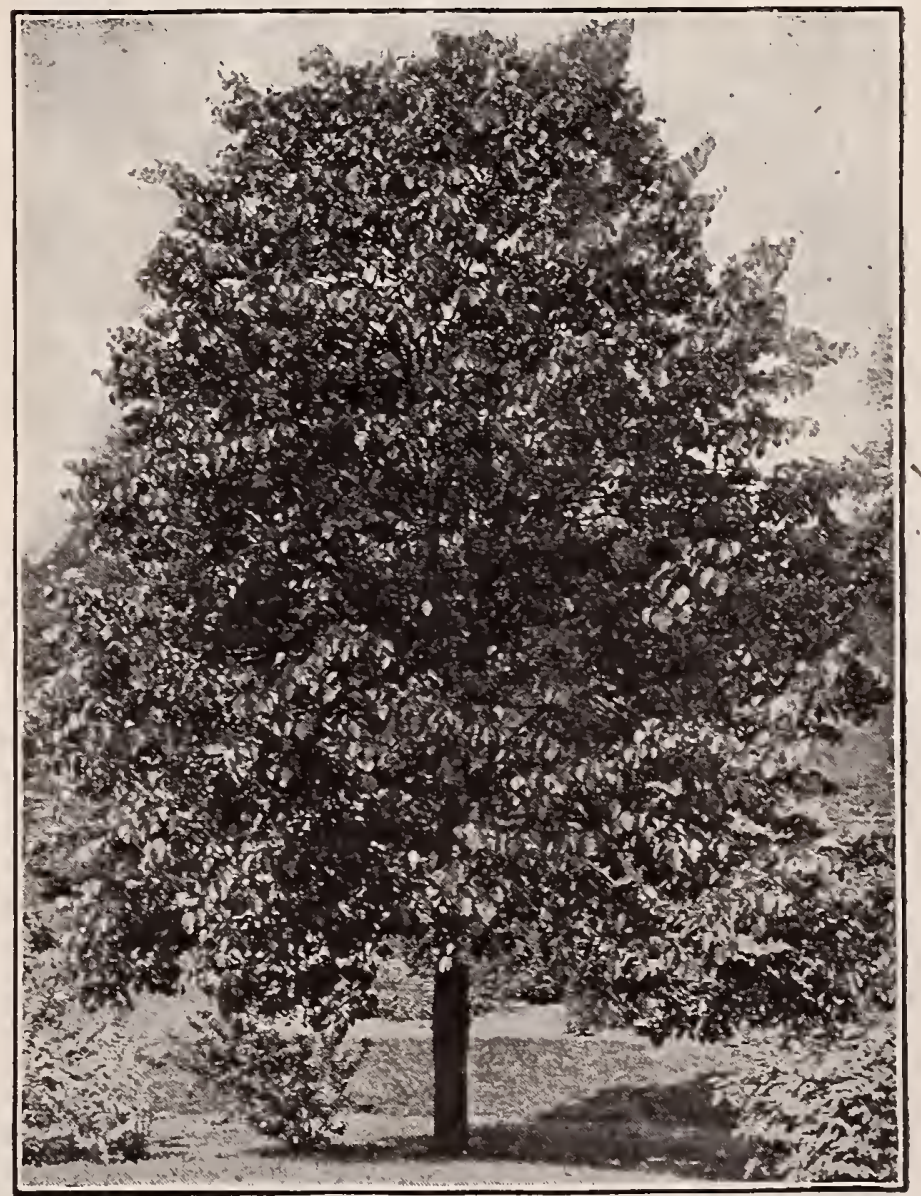

\section{American Linden}

American Linden or Basswood.-A rapid growing, large-sized, beautiful native tree, with very large leaves and fragrant flowers. 6 to $8 \mathrm{ft}$., 75 cts. each.

European Linden.-A very fine pyramidal tree of large size, with large leaves and fragrant flowers. 6 to $8 \mathrm{ft}$., $75 \mathrm{cts}$. each. 

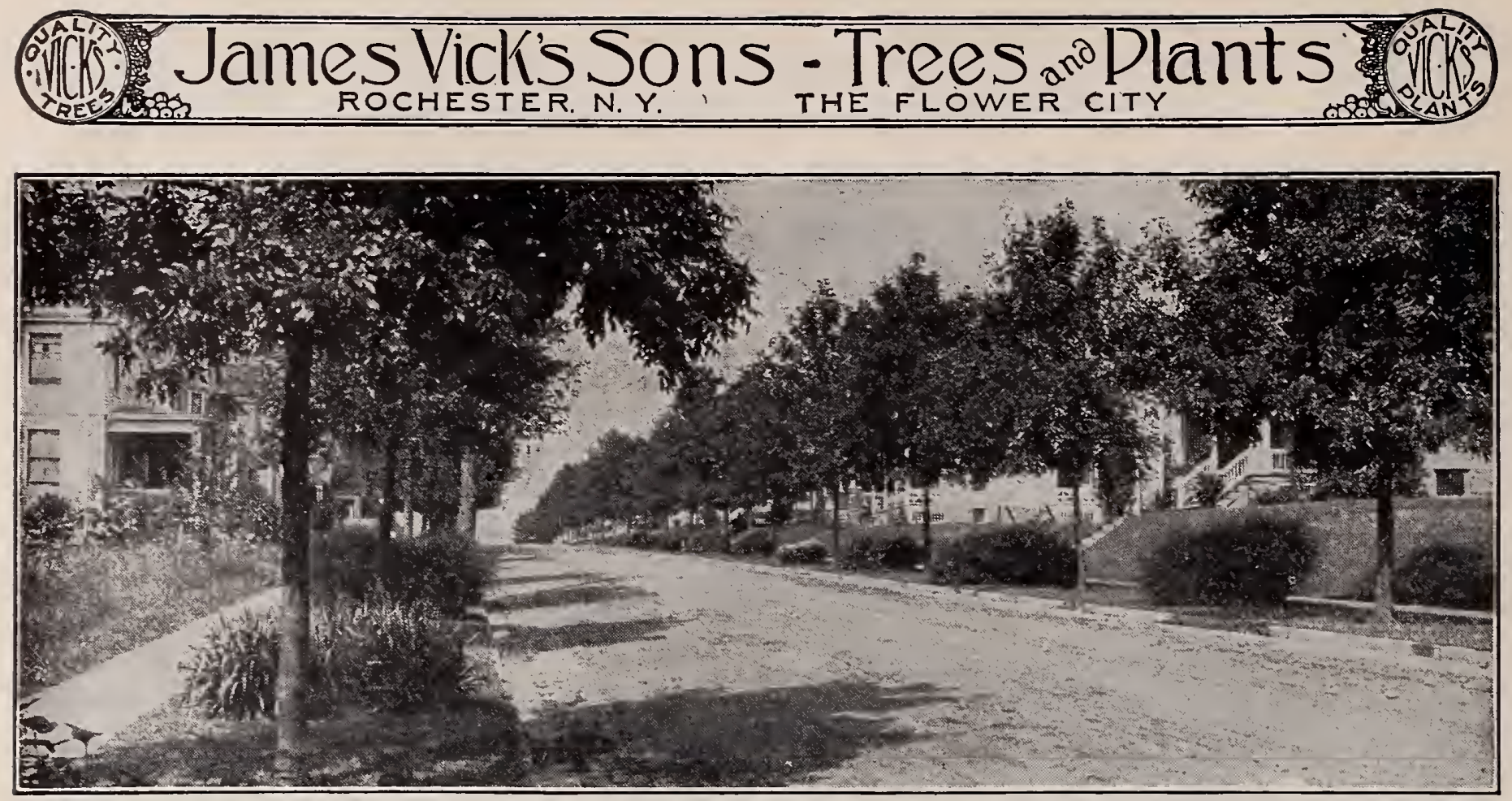

Norway Maple for Street Planting

Laburnum, or Golden Chain.-A native of Europe with smooth shining foliage. Bears long pendant racemes of golden flowers in June. Very showy and beautiful. 50 cts. each.

American White Oak.-One of the finest American trees, of large size and spreading branches; leaves lobed, pale green above and glaucous beneath. 5 to $6 \mathrm{ft}$., $\$ 2.00$ each.
Double White-flowered Peach.-Very ornamental. Flowers pure white and double; superb. Perfectly hardy. 3 to $4 \mathrm{ft}$., $50 \mathrm{cts}$. each.

Double Red-flowered Peach.-Flowers semi-double, bright red; superb. 3 to $4 \mathrm{ft}$., 50 cts. each.

American Elm.-The most admired of all American trees. It is very attractive in any suitable location, is entirely hardy and easily transplanted. There are more elm trees planted along our streets and highways than any other one variety. This on account of its dense green foliage, which spreads out from overhead, covering a suitable space of ground in proportion to the size of the tree, which makes it the finest shade tree in the world.

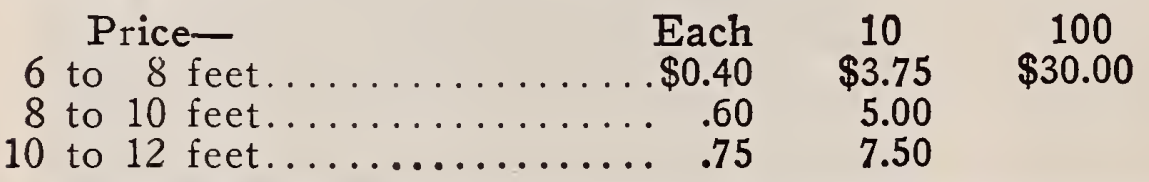
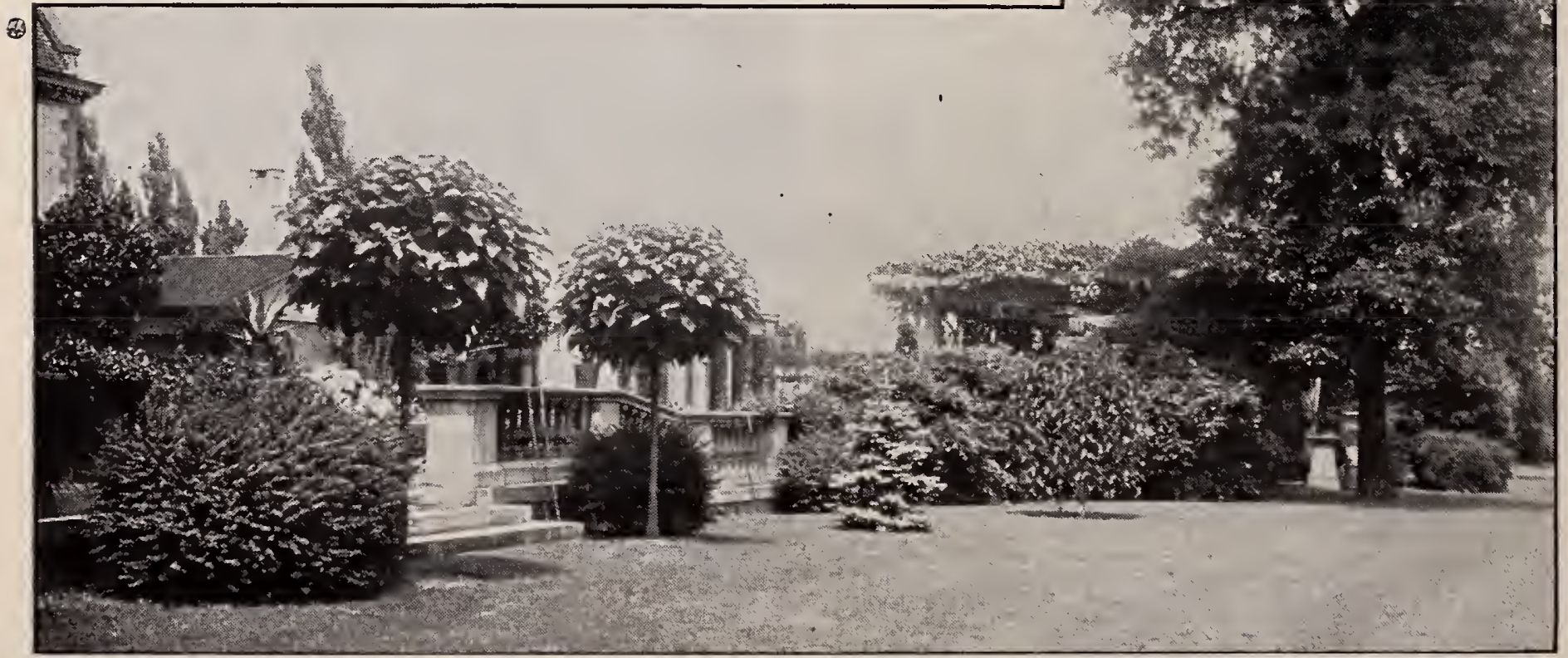


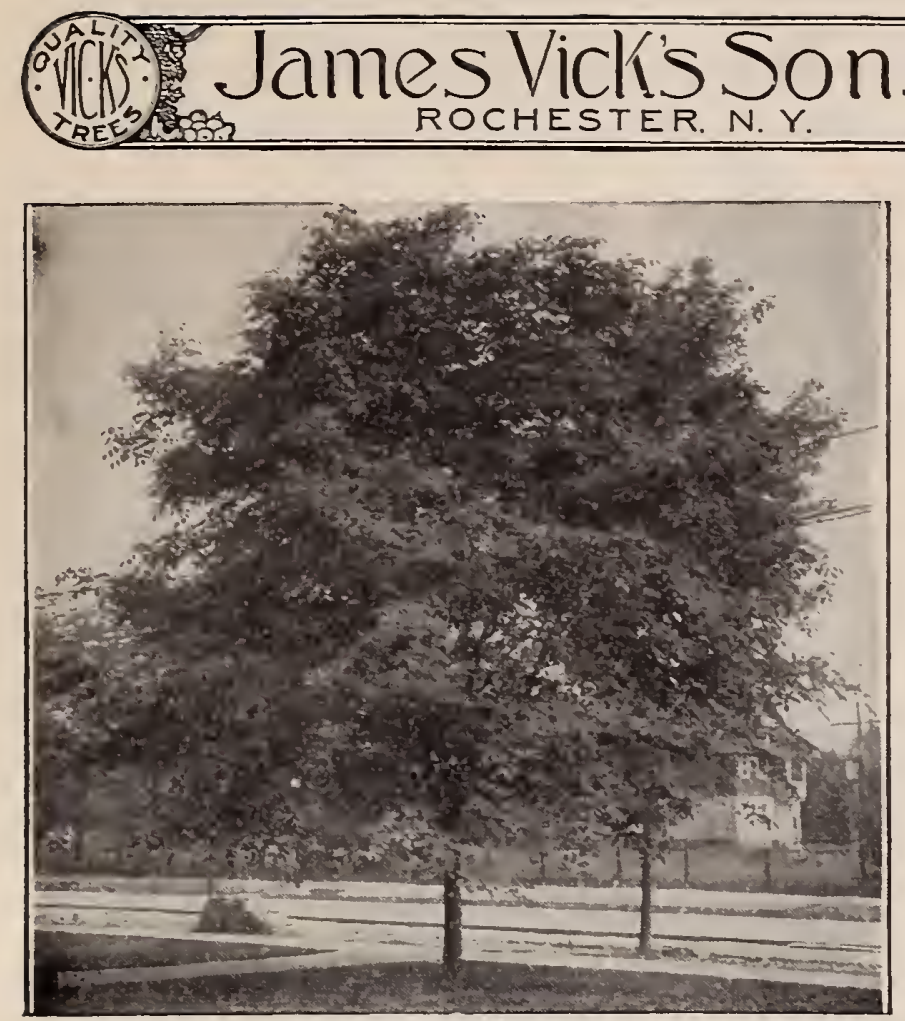

Sugar Maple

Maple, Sugar or Rock.-A native tree valuable for its production of sugar and wood. Very stately in form, rapid grower and has fine foliage. Valuable ornamental variety.

$\begin{array}{rrrr}\text { Price- } & \text { Each } & \text { Ten } & \text { Hundred } \\ 6 \text { to } 8 \mathrm{ft} \ldots \ldots \ldots \ldots & \$ 0.70 & \$ 6.00 & \$ 50.00 \\ 8 \text { to } 10 \mathrm{ft} \ldots \ldots \ldots \ldots & 1.00 & 9.00 & 80.00 \\ 10 \text { to } 12 \mathrm{ft} \ldots \ldots \ldots \ldots & 2.00 & 15.00 & 120.00\end{array}$

Maple, Norway.-One of the most beautiful and desirable trees known, of large size, perfect outline, with deep green foliage. Its compact habit, stout, vigorous growth, freedom from disease and insects, render it one of the most desirable trees for the street, park or garden.

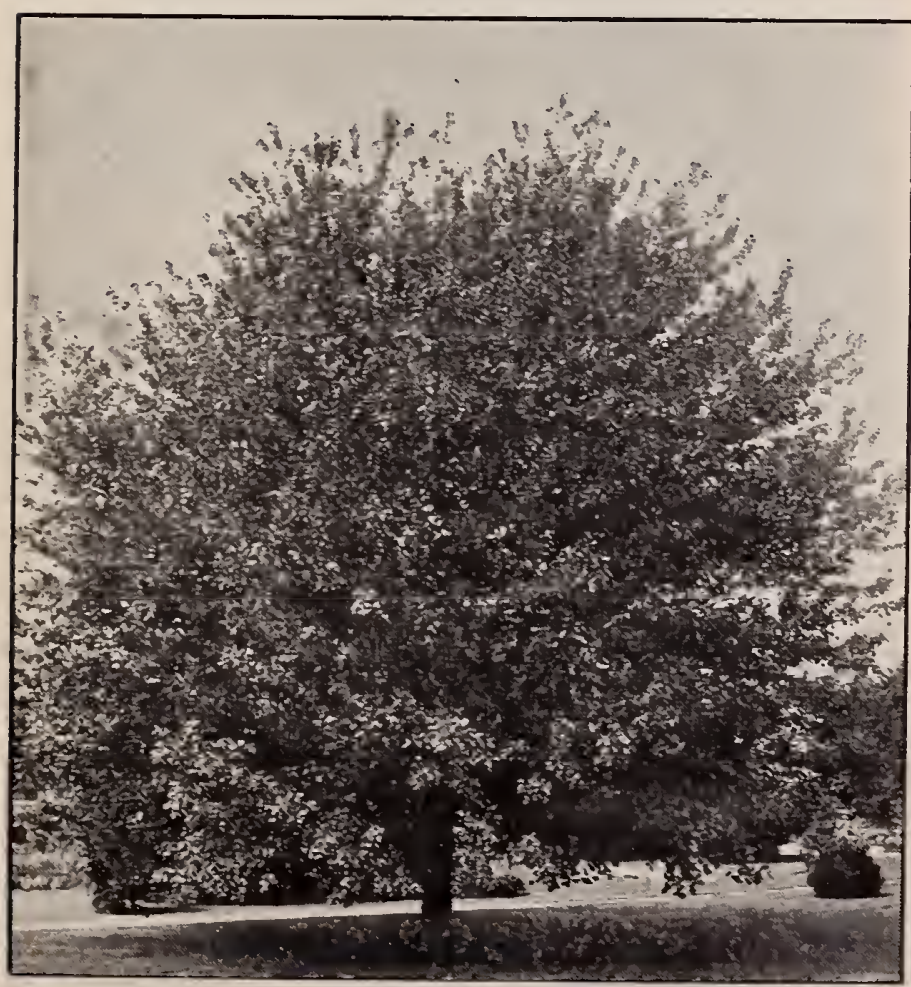

Purple Leaf Maple
THEFLOWER CITY

$\begin{array}{rrrr}\text { Price- } & \text { Each } & \text { Ten } & \text { Hundred } \\ 8 \text { to } 10 \mathrm{ft} \ldots \ldots \ldots \ldots & \$ 0.75 & \$ 7.00 & \$ 60.00 \\ 0 \text { to } 12 \mathrm{ft} \ldots \ldots \ldots \ldots & 1.25 & 10.00 & 80.00\end{array}$

Extra large trees for immediate results: $2 \mathrm{I} / 2$ to $3 \mathrm{in}$. caliper.......... $\$ 5.00$ each 3 to + in. caliper...........\$ $\$ 7.00$ each

Maple, Weir's Cut Leaf.-This is one of the most remarkable and beautiful trees with cut or dissected foliage yet offered. Its growth is rapid, shoots slender and drooping, giving it a habit almost as graceful as the cut-leared birch. Foliage is abundant, leaves green on the top, silvery underneath. One of the most valuable and handsome of the ornamental trees.

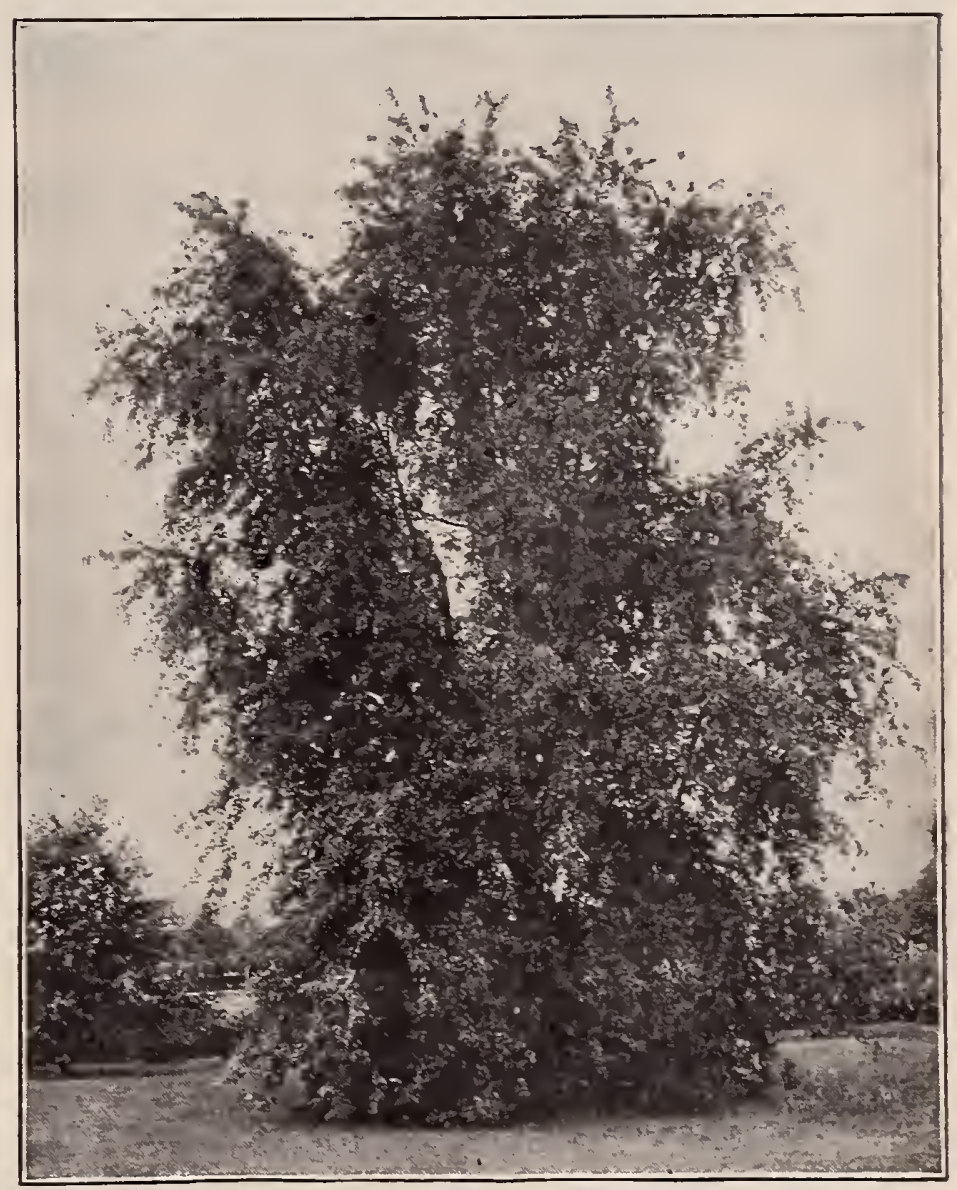

Wier's Cut Leaf Maple

$\begin{array}{lrrr}\text { Price- } & \text { Each } & \text { Ten } & \text { Hundred } \\ 6 \text { to } 8 \mathrm{ft} \ldots \ldots \ldots . \$ 0.60 & \$ 5.00 & \$ 40.00 \\ 8 \text { to } 10 \mathrm{ft} \ldots \ldots \ldots . & . \ldots 0 & 7.00 & 65.00\end{array}$

Maple, Ash-Leaved or Box Elder.-A fine rapid growing variety, with handsome, light grcen foliage and spreading head; very hardy, desirable for street planting and succeeds in many sections where other varieties do not thrive. $50 \mathrm{cts}$. each, $\$ 4.00$ for 10.

Maple, Schwedler's or Purple-Leaf.-A beautiful variety of Purple-Leaf Norway with long shoots and leaves of bright purple and crimson color, which change to purplish green on older leaves. 6 to $8 \mathrm{ft}$., $\$ 1.00$ each. 


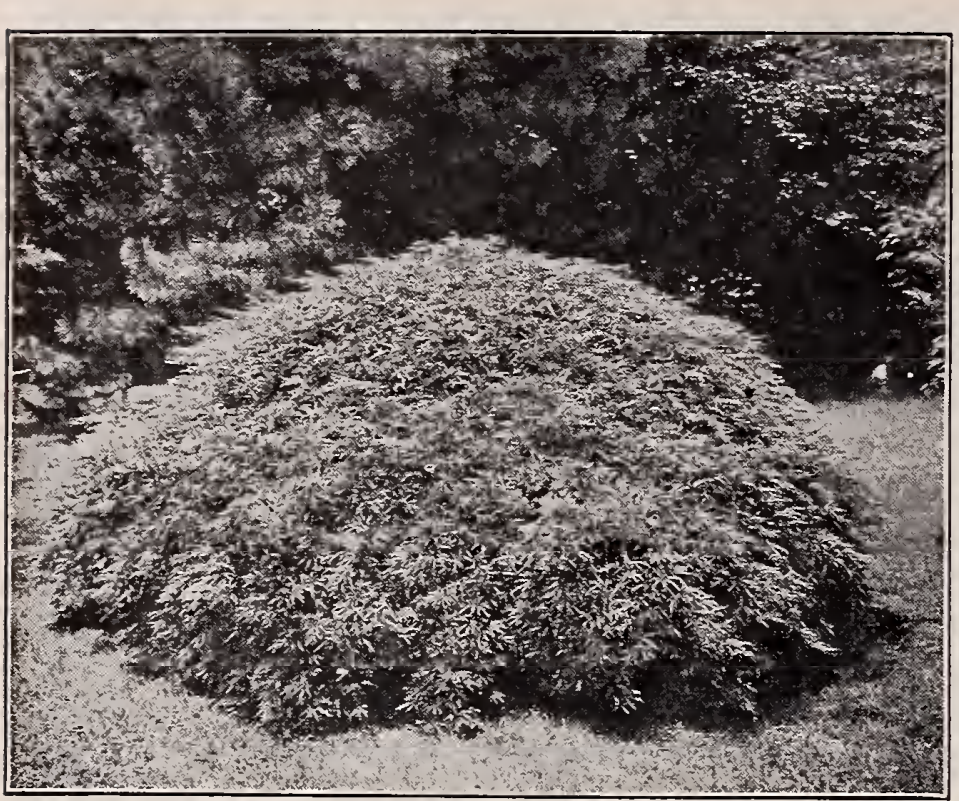

Japan Blood-Leaved Maple

Maple, Japan Blood-Leaved. - Dwarf habit and roundish form. Foliage very handsome, leaves cut and serrated, redishcrimson in June, changing to dark purple which it retains all summer. Price of specimens with ball of earth on roots burlaped, $\$ 2.00$ each.

Maple, Silver Leaf or Soft Maple.-A well-known native tree of rapid growth, large size, and rounded form. Foliage bright green above and silvery-white beneath; tree very hardy and easily transplanted. One of the most useful trees.

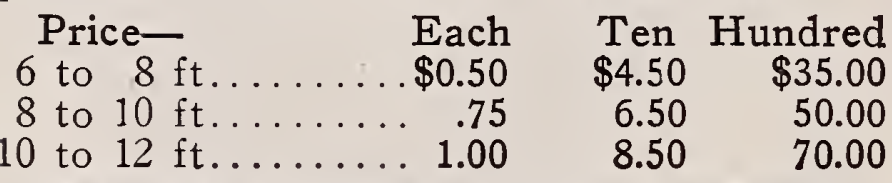

Magnolia Acuminata (Cucumber Tree).A beautiful pyramidal-growing native species, growing to the height of 60 or 70 feet, with large glossy leaves; flowers yellow, tinted with bluish purple. Price-75 cts. each.

Magnolia Speciosa (Showy Flowered Magnolia).-Of shrubby, branching habit, flowers smaller than Soulangeana, and lighter in color; fully a week later; and remain in perfect condition upon the tree longer than those of any other Chinese variety. One of the hardiest. $\$ 2.00$ each.

Magnolia Soulangeana (Soulange's Magnolia). - Shrubby and branching while young, but becoming a fair sized tree. Flowers white and purple, cup-shaped and 3 to 5 inches in diameter. Foliage large, glossy and massive. $\$ 2.00$ each.

Thorn, Paul's New Double Flowering.This tree deserves to be classed among the most beautiful of all ornamentals. It is a dense, low grower, and occupies but little space; well adapted to beautify small grounds. Flowers are bright carmine red color and bloom in May and June. Price3 to $4 \mathrm{ft}$., $50 \mathrm{cts}$. each.
Thorn, Double White.-Has small, double white flowers. A highly ornamental variety, on account of both foliage and flowers. Makes a very striking contrast when planted with the double scarlet. Strong trees. 50 cts. each. Scarlet, same price.

Oriental Plane.-This tree is fast becoming popular for street planting. It is a rapid, upright, clean grower and long lived; beautiful, dense foliage; it is not affected by the air of cities nor by insects. 6 to 8 ft., 75 cts. each.

Purple Leaved Plum.-Prunus Pissardii, small but exceedingly ornamental tree of compact habit. The young trees are crimson, changing to dark purple, and retaining this hue throughout the season better than most other purple-foliaged plants. 50 cts. each.

Double Flowering Plum.-A beautiful shrub with slender branches densely clothed with elegant double rosy flowers in early summer. Resembles the Flowering Almond. 50 cts. each.

Mulberry, Tea's Weeping.-One of the finest, most graceful and satisfactory of weeping trees. Umbrella shaped head, with slender willowy branches drooping to the ground. It has beautiful glossy foliage, handsomely cut or divided into lobes. It is perfectly hardy. $\$ 1.00$ each.

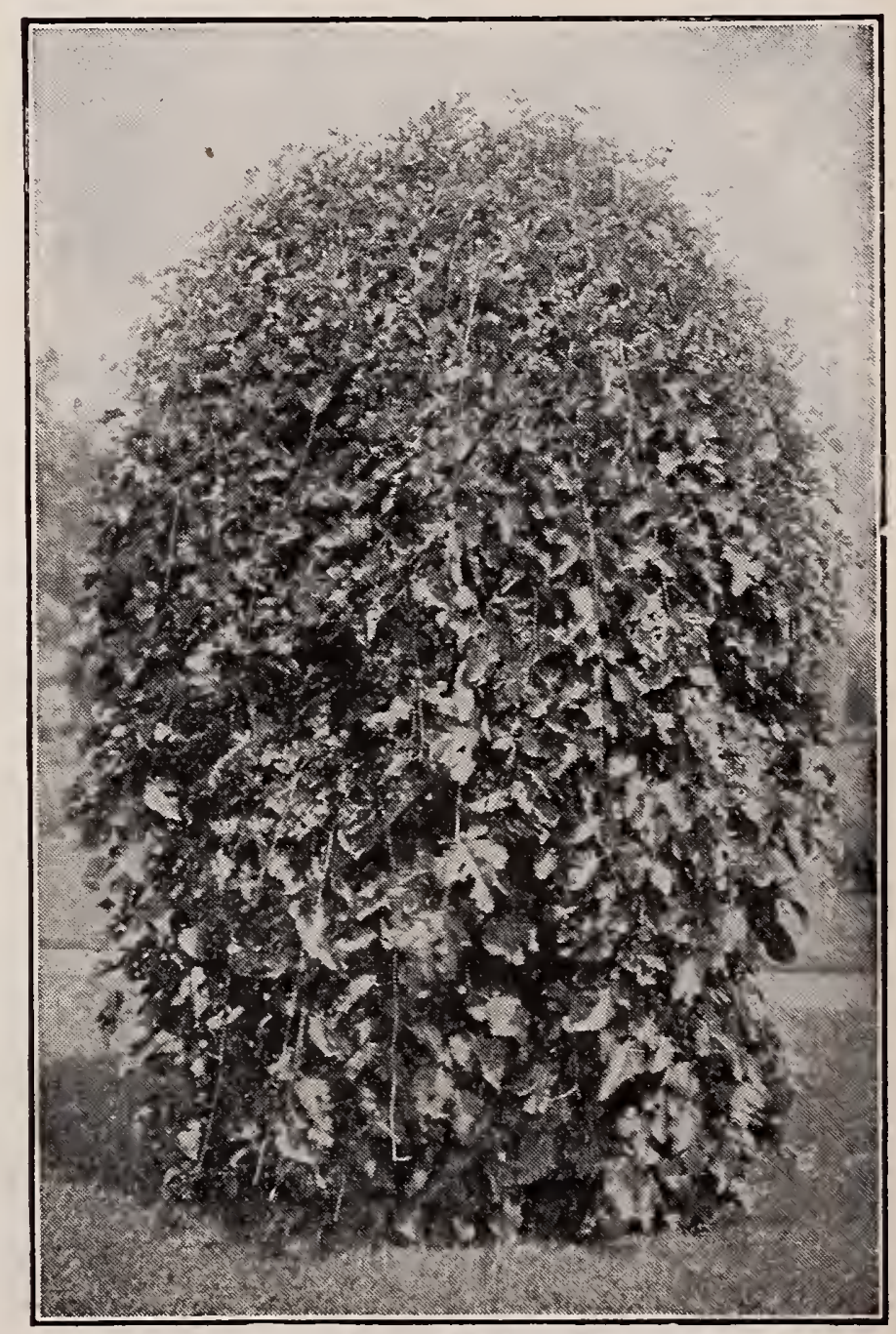

Mulberry, Tea's Weeping 


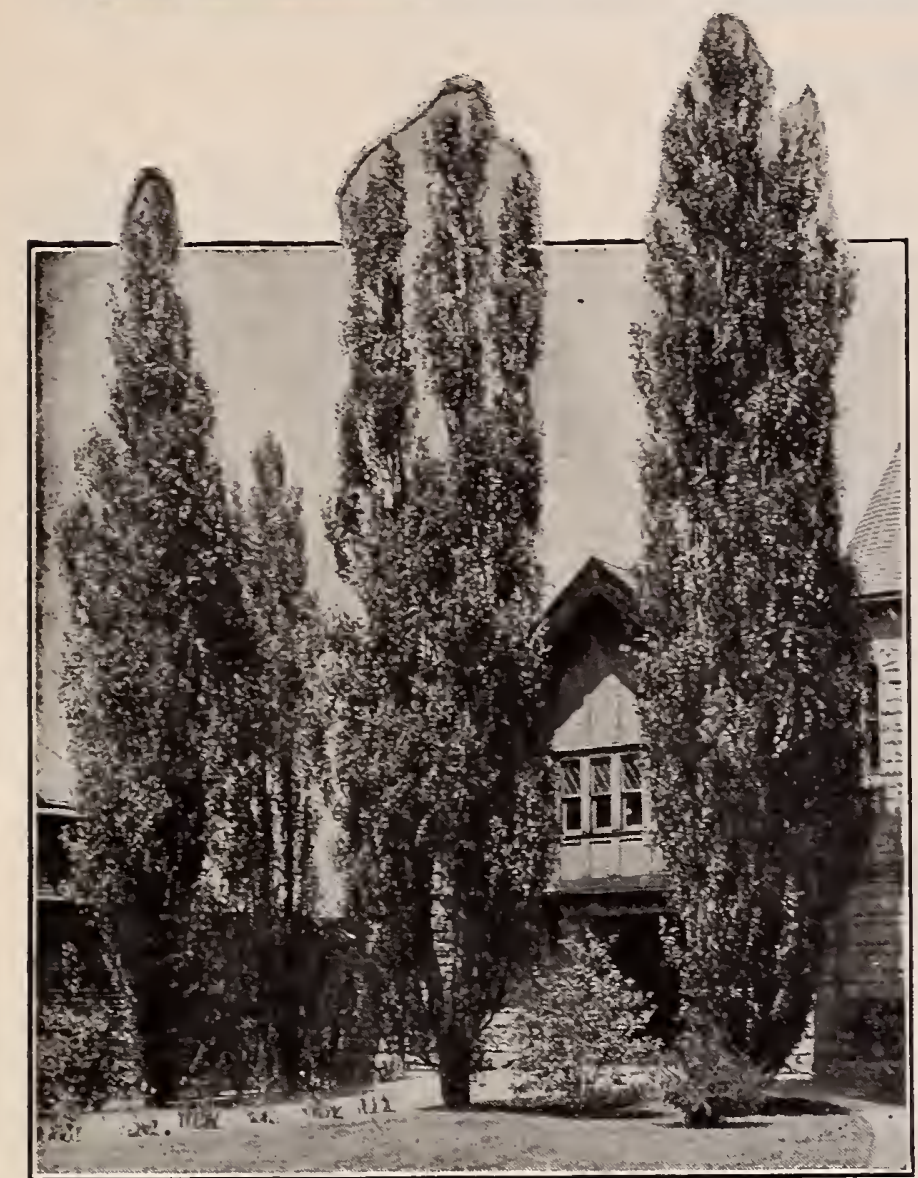

Lombardy Poplar

Mulberry, Downing.-This tree is not alone valuable for the large refreshing berries it bears, but is very handsome as a lawn or street tree. 4 to $5 \mathrm{ft}$., $50 \mathrm{cts}$. each.

Mulberry, Russian.-A hardy variety of mulberry. Tree is a rapid grower; foliage is abundant. 7 to $8 \mathrm{ft}$., $40 \mathrm{cts}$. each.

Lombardy Poplar.-Grows to a height of from 100 to 150 feet. Well known and remarkable for its erect, rapid growth and tall, spiry form. Indispensable in landscape gardening, to break the ordinary and monotonous outlines of most other trees.

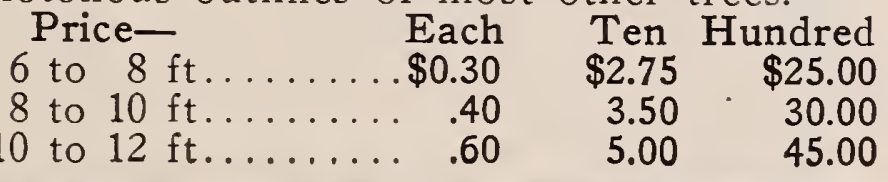

Carolina Foplar.-One of the most rapid growing trees; its branches are spreading, the leaves are large, handsome and glossy. The best of the poplars, and especially adapted to planting in large cities, where it resists the smoke and gas and soon afford.s a dense shade.

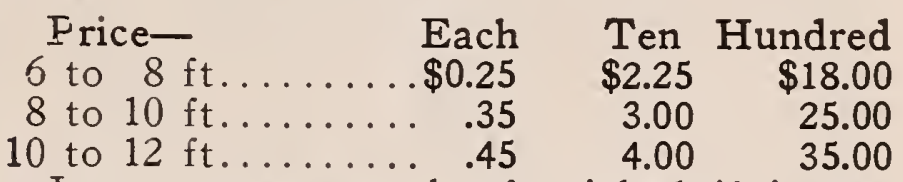

Larger trees can be furnished if immediate results are necessary. $\$ 1.00$ each, $\$ 9.00$ for ten.

Walnut, Japan.-A choice imported variety, grows with great vigor, forming a handsome head without pruning, and has withstood a temperature of 20 degrees below zero without injury. The shell is a little thicker than that of the English Walnut, which it resembles in a general way; the kernels are meaty, delicate, and can be removed entire. The trees begin to bear when two or three years old. $50 \mathrm{cts}$. each.

English, Persian, or Madeira.-A fine, lofty-growing tree, with handsome, spreading head; produces large crops of thinshelled, delicious nuts which are always in demand at good prices. An exceedingly handsome tree for the lawn. 50 cts. each.

American Black.-The large, oily nuts are borne in heavy crops. They are much relished by all persons, old and young, and always sell at a fair price. The tree grows quite fast; its dark, rich wood is exceedingly valuable. 50 cts. each.

Willow, Babylonica.-Our common well known weeping variety; forms a large, round-headed, graceful tree; requires plenty of room, and where space can be spared, is quite desirable. 75 cts. each.

Tulip Tree.-A magnificent native tree with broad, glossy, fiddle-shaped leaves and beautiful tulip like flowers; allied to the Magnolias, and like them difficult to transplant unless of small size. $\$ 1.00$ each.

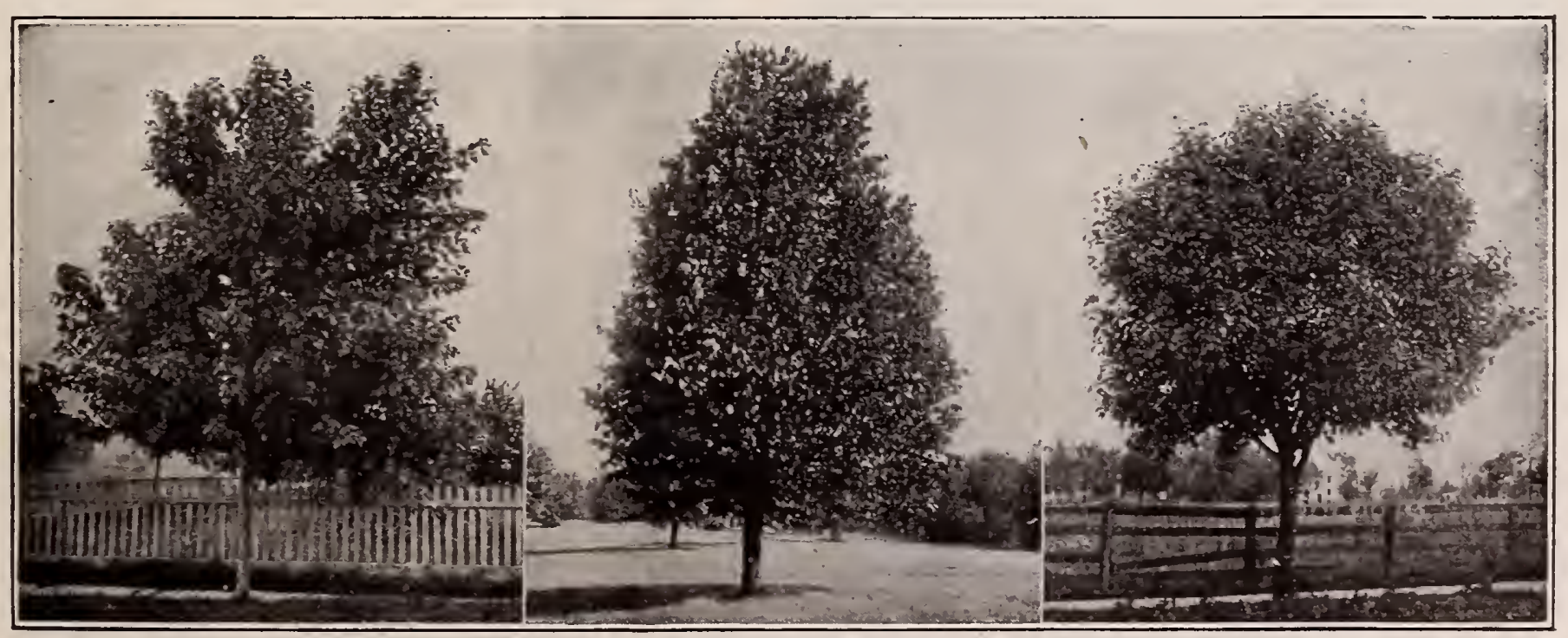




\section{Evergreens}

Kosters (Colorado Blue Spruce).-A most beautiful variety, discovered and disseminated from the Rocky Mountains, it is the nearest blue of any evergreen, very distinct in foliage and growth; fine compact habit. It is in great demand as a lawn tree throughout the Eastern states, where fine specimens are established, proving it the best of all evergreen trees for the lawn. Foliage rich blue or sage color. All with ball of earth burlapped.

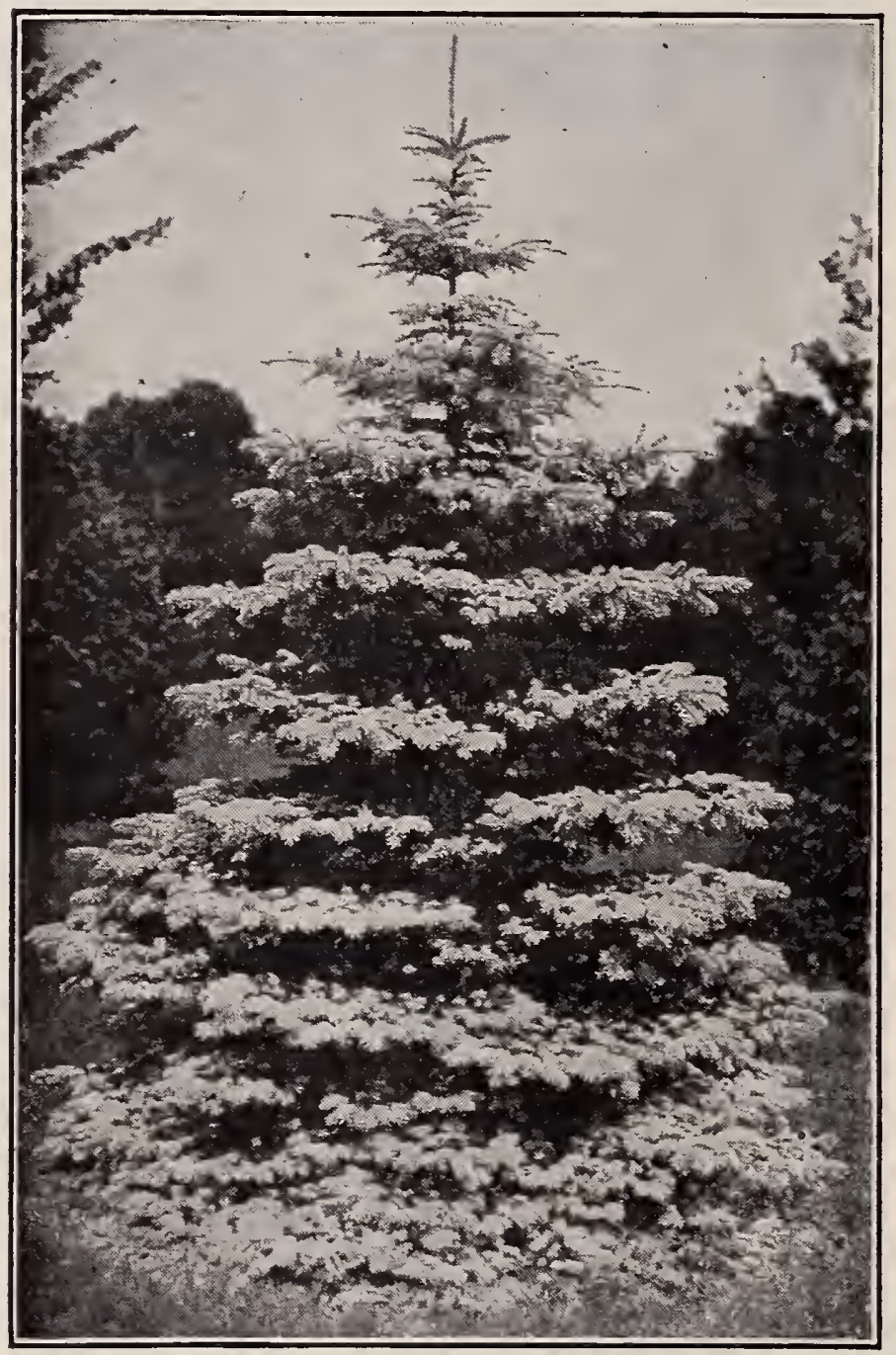

Kosters Blue Spruce

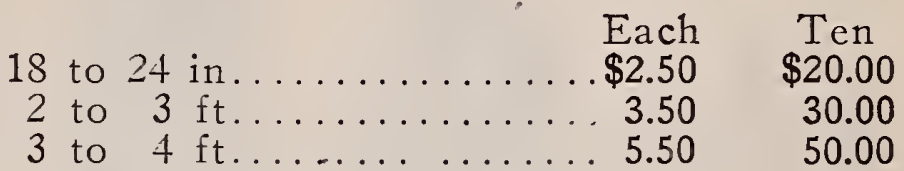

We have larger Blue Spruce we can make you special prices on.

Norway Spruce.-An elegant tree; extremely hardy, of lofty, rapid growth and pyramidal form. The branches assume a graceful, drooping habit when the tree attains 15 to 20 feet in height. One of the most popular evergreens for planting, either as single specimen trees, or in masses for effect or shelter. It is one of the best evergreen hedge plants.

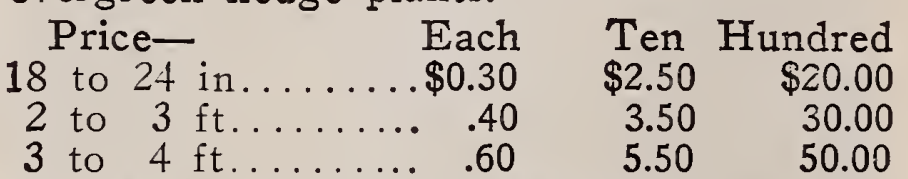

American Arbor Vitae.-Much used for hedges, screens, singly on lawns or in tubs for porches. A handsome little tree, and if allowed to grow naturally will be tall and pyramid-shaped. Can be trimmed and kept in any form and height. In summer the foliage is bright green above, yellowish beneath. For single planting:

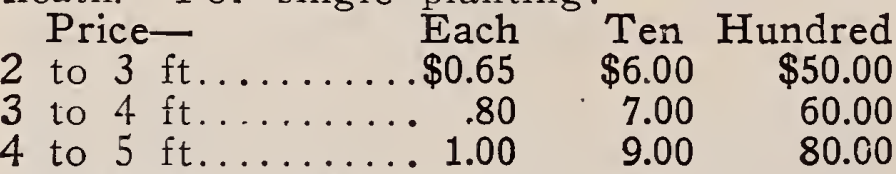

Austrian Pine.-A robust grower with long, dark stiff needles. Does well on all soils and especially well for seashore planting. 2 to $3 \mathrm{ft}$., $\$ 2.00$ each.

White Pine.-A native tree, valuable for timber purposes. Light, silvery foliage; used for hedges as can be clipped like a shrub. 2 to $3 \mathrm{ft} ., \$ 1.50$ each.

Scotch Pine.-A dark, tall evergreen, with bluish foliage and rugged shoots. Hardy, and grows even on the poorest soils. 2 to $3 \mathrm{ft}$., $\$ 1.25$ each.

Irish Juniper.-Very erect and tapering in its growth, forming a column of deep green foliage; a pretty little tree or shrub, and for its beauty and hardiness is a general favorite. 3 to $4 \mathrm{ft}$., $\$ 1.00$ each.

\section{BARRELED NEW YORK STATE APPLES FOR SALE}

On the inside of the front cover of this book is shown a picture of one corner of our orchard, which is under the supervision of the State Experimental Station. Last season we offered the fruit from these trees to our friends and customers. This year we shall be prepared to fill orders for apples in any quantity. The fruit will be carefully sorted and graded up to the New York State Standard. No order will be taken for less than one barrel. Write us for prices in August or September when we will have definate knowledge of the crop and can make you prices. 


\section{Hedges and Windbreaks}

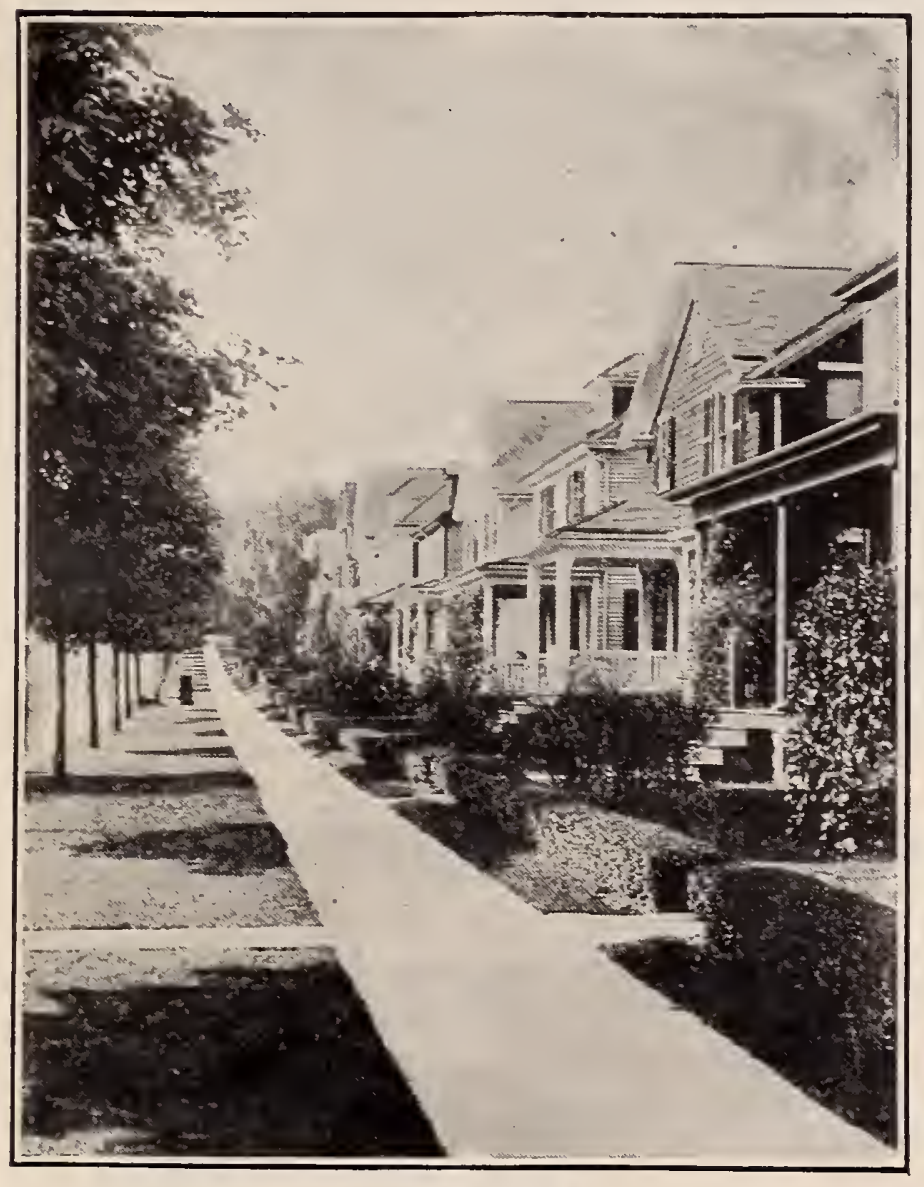

California Privet

California Privet.-Rapid grower with bright, shining leaves. This shrub grows freely in almost any soil, is comnact in form and can be trimmed to any desired shape; flowers during June and July. Desirable for hedges.

Price-

12 to $18 \mathrm{in} \ldots \$ 0.75$

18 to 24 in.... .90

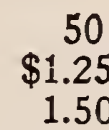

100

1000

2 to $3 \mathrm{ft} . . . .1 .00$

1.50

$\$ 2.50$

$\$ 20.00$

2.00

3.00

25.00

Ibota Privet.-Eren hardier than the California. A rapid grower with bright shining leaves. This is known as the upright and has been found to be perfectly hardy in the north. For the colder sections this is undoubtedly the best of the Privet for hedges. Flowers white in upright panicles, fruit blue black.

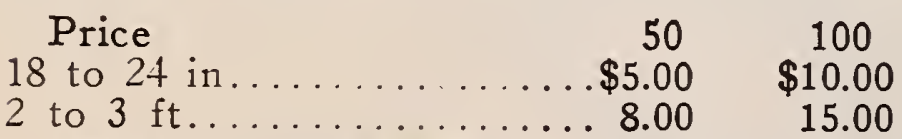

Berberry Thunbergii.-This shrub rie particularly recommend to our patrons for a hedge plant. Its hardiness, bushiness and beautiful foliage promise to make it our most popular hedge. The foliage turns a beautiful copper color in the fall and brilliant fruit remain on all winter.

Price- 25

12 to 18 in ...... $\$ 3.50$

18 to 24 in ....... 4.00
Berberry, Purple-Leaved.-A fine shrub, growing three to five feet high, with violet purple foliage and fruit; blossoms and fruit bcautiful; very effective in groups, hedges or planted by itself.

$\begin{array}{lrrr}\text { Price- } & \text { Each } & 25 & 100 \\ 2 \text { to } 3 \mathrm{ft} \ldots \ldots \ldots \ldots & \$ 0.25 & \$ 4.00 & \$ 15.00\end{array}$

Norway Spruce.-The most desirable and most popular evergreen for all purposes. It is extremely hardy, and will grow in any soil under all conditions. Can be kept as a low hedge or let grow 20 or 30 feet to act as a wind break.

$\begin{array}{rrrr}\text { Price }- & 10 & 50 & 100 \\ 18 \text { to } 24 \text { in ...... } \$ 3.00 & \$ 10.00 & \$ 18.00 \\ 2 \text { to } 3 \mathrm{ft} \ldots \ldots \ldots .3 .50 & 13.00 & 25.00\end{array}$

Arbor Vitae.-A hedge evergreen that can be very easily trimmed to any shape or size desired. A very dense growing hedge that does especially well on moist ground. It is used to a great extent as a wind break and as a tall hedge around country property.

$\begin{array}{rrrr}\text { Price- } & 10 & 50 & 100 \\ 18 \text { to } 24 \text { in ..... } \$ 2.50 & \$ 9.00 & \$ 18.00 \\ 2 \text { to } 3 \mathrm{ft} \ldots \ldots \ldots .3 .50 & 13.00 & 25.00\end{array}$

JAMES VICK'S SONS, Established 1849-66 years selling by mail-dealing direct with the customer.

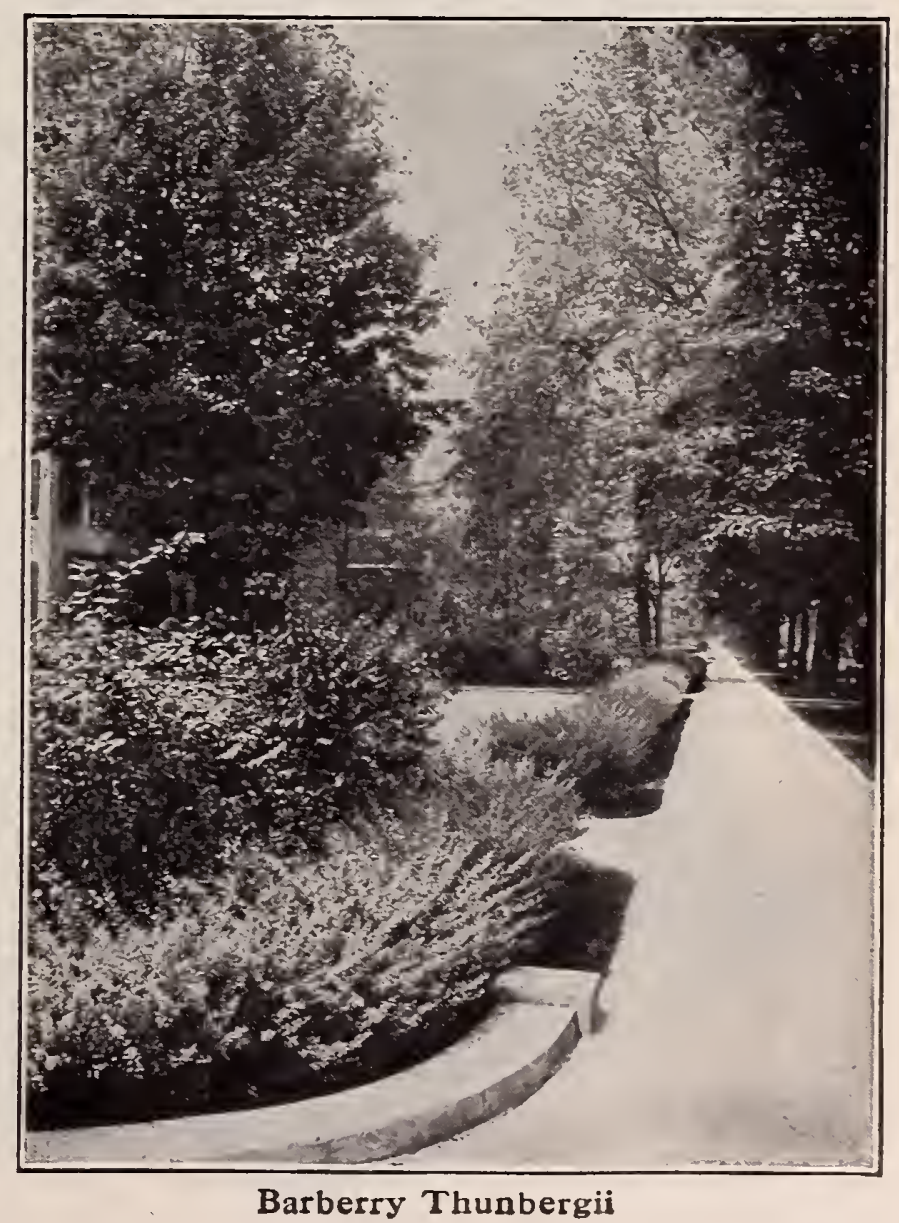




\section{Strawberries}

Strong Plants Freshly Dug - Shipped Direct From the Field $\begin{array}{rrrrrrr}\text { PLANTS SENT BY PARCEL } & \text { POST } & \text { OR } & \text { EXPRESS } & \text { PREPAID AT } & \text { THESE PRICES } \\ 12 & 25 & 50 & 100 & \$ 250 & 1000 \\ 30 \mathrm{c} & 50 \mathrm{c} & 75 \mathrm{c} & \$ 1.25 & \$ 2.00 & \$ 6.00\end{array}$

Brandywine-A large, broad, heart-shaped berry, delicious. Medium red color, flesh is firm. Will thrive on most any kind of soil. A midseason berry.

Bubach-Among the leaders of old standard varieties. Fruit large and handsome, conical, bright scarlet, moderately firm, rich in flavor. Succeeds on light or heavy soil. Desirable for home use and market. Season early to medium.

Chesepeake-Popular, new, quality berry. Flesh dark red, juicy, sweet, highly flavored. For quality in the highest degree plant Chesepeake.

Early Ozark-Very early, large, bright red, strong grower, abundant bearer. Best early home garden and commercial berry.

Gandy-A large, late berry, heavy yielder, strong grower. Fruit very firm, and of good quality. On the market brings fine prices.

Klondike-Medium early, good, uniform size, firm, fine quality. Ships and keeps well.

Senator Dunlap-Very hardy and very productive. Berries good size, bright glossy red, good quality. Ripens early and fruits for a long period.

Stevens Late Champion-Large, fine colored, late, productive berry. Well known and well liked everywhere.

William Belt-Well known. High quality, large, bright crimson berry. Juicy and sweet. Ripens all over, no green tips.

Progressive - Fall Bearing - With Progreesive planted in your garden you can have strawberries from May until November. No longer an experiment but a home garden and commercial success. Bears fruit until the ground is frozen hard in the fall. Berries bright red, medium size, good quality. Prices-20c each; $\$ 1.50$ for $12 ; \$ 2.75$ for $25 ; \$ 7.00$ for 100 . Other Varieties We Sell :
Climax
Glen Mary
Marshall
Haverland
Sample
Pride of Michigan

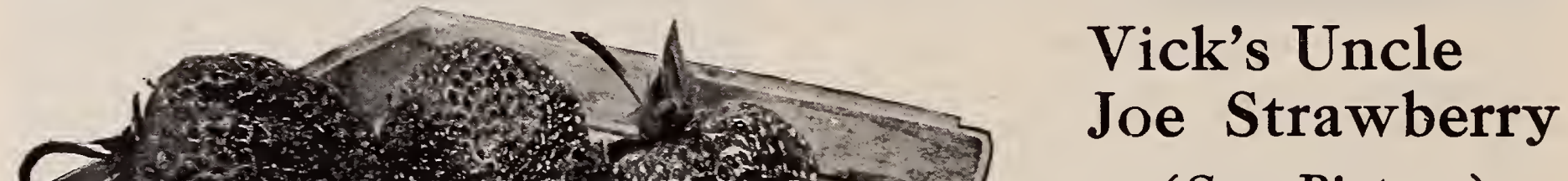

(See Picture)

For a fancy bright red table berry, large and of high quality, it cannot be beaten. Flesh is tender and delicious with a rich sub-acid wild flavor.

Plants strong growing and very hardy. If you wallt size and quality plant Vick's Uncle Joe.

\section{PRICES :}

Dozen, 50 cents ; 25 plants, 75 cents; 100 plants, $\$ 2.50$; 1000 plants, $\$ 8$.

Order Vick's Uncle Joe early. Our supply is limited. 


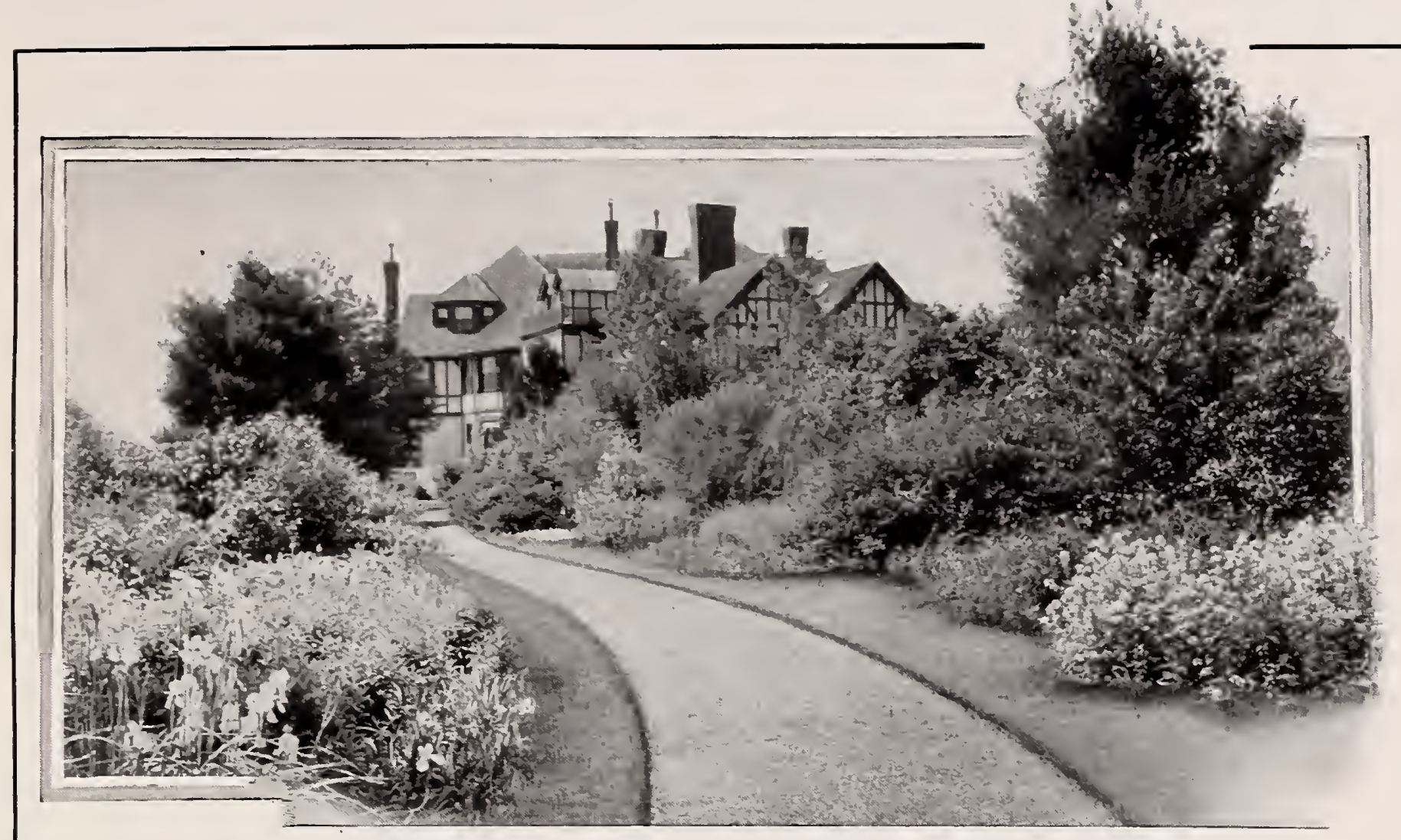

\section{We Help You With Your Plantings}

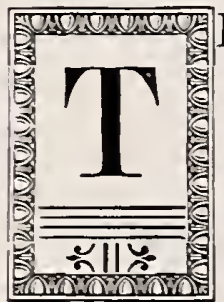

HAT we may fill the wants of those requiring the services of experienced men to advise what, where and how to plant to beautify the grounds around their homes, a Landscape Department has been added. It is surprising how much better your place can be made to look with the expenditure of but very little money. A simple planting of a few inexpensive ornamental trees and shrubs, shading and ornamenting the front lawn, and some quick bearing fruit trees, vines and bushes in your garden, will add greatly to the appearance and value of your home and to your own comfort and enjoyment.

The man who has planted in his garden some well selected varieties of fruit trees and bushes that give a succession of fruit for his table the entire season can well be envied by his less fortunate neighbors.

Send us your list of wants. If you are not sure just what to plant ask us about it. Our experience is at your service free of any charge. Sketches will be made for you, showing where each tree and bush should be planted to give you the best results. If you are the owner of a large place and wish special landscape advice given and work done, we are in a position to furnish you with plans and estimates at reasonable prices.

\section{LANDSGAPE AND NURSERY DEPARTMENT} JAMES VICK'S SONS, $\underset{N \in W \text { Y YORK }}{\operatorname{ROCHESTER}}$ 


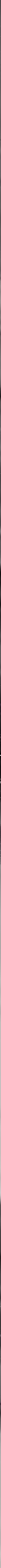
SEE PAGE EIGHT 